REVISTA DE DERECHO UNED, NÚM. 27, 2021

\title{
LAS ORGANIZACIONES NO GUBERNAMENTALES DE DESARROLLO Y EL RÉGIMEN FISCAL DE LAS ENTIDADES SIN FIN DE LUCRO
}

\section{NON-GOVERNMENTAL DEVELOPMENT ORGANISATIONS AND THE TAX REGIME FOR NON-PROFIT ENTITIES}

\author{
Manuel J. CaAmaño Rial \\ Técnico de Administración General, rama jurídica. Abogado. \\ Doctorando del Programa de Doctorado en Derecho \\ y Ciencias Sociales de la UNED ${ }^{1}$
}

Sumario: I. Introducción.-II. Las Organizaciones no gubernamentales de desarrollo (ONGDs)._-III. El Reglamento del Registro de ONGDs de 2015 y la restricción del concepto de ONGD. III.A. La cooperación al desarrollo y los títulos competenciales. III.B. El RONGDs como autoproclamado custodio de la aplicación de los incentivos fiscales a la iniciativa privada en el ámbito de la cooperación al desarrollo. III.C. La (pretendida) ausencia de instrumentos de cooperación entre los Registros de ONGDs. III.D. La ruptura de la paridad entre el Registro de la AECID y los Registros autonómicos III.E. La finalidad esencial del RONGDs: la publicidad formal. III.F. Los vínculos de dependencia: el carácter de no gubernamental. III.G. Los vestigios de la exigencia de haber desarrollado sus actividades con anterioridad. III.H. Las ONGDs como entidades dotadas de una estructura estable.-IV. La inscripción en el Registro de ONGDs como "condición (supuestamente) indispensable» para el disfrute del régimen fiscal de la Ley 49/2002. IV. A. Reca-

1 Programa de Doctorado en Derecho y Ciencias Sociales. Equipo 1, Derecho Público y Operadores Económicos. Línea 3, Operadores económicos y tráfico jurídico. Derecho Financiero y Tributario. Escuela Internacional de Doctorado de la UNED (EIDUNED). Universidad Nacional de Educación a Distancia (UNED). 
pitulando. IV.A.1. Hipótesis 1: La irrelevancia en el régimen de la Ley 49/2002 de la ausencia de inscripción en el/los Registro/s de ONGDs. IV.A.2. Hipótesis 2: La inscripción en el/los Registro/s de ONGDs como conditio sine qua non para el disfrute del régimen fiscal de la Ley 49/2002 sólo para las que sean asociaciones no declaradas de utilidad pública. IV.A.3. Hipótesis 3: El Registro de ONGDs como el «registro correspondiente» del art. 3.7 de la Ley 49/2002. -V. La (controvertida) necesidad de la declaración de utilidad pública como requisito para disfrutar como ONGDs del régimen de la Ley 49/2002._VI. Conclusiones.

Resumen: En el presente trabajo se examina, por un lado, la cuestión de si, en el concreto caso de las Organizaciones no gubernamentales de desarrollo (ONGDs) constituidas como asociaciones, les resulta necesario estar declaradas de utilidad pública para poder ser consideradas «entidades sin fines lucrativos» y disfrutar de los beneficios que les reconoce la Ley 49/2002, de 23 de diciembre, o si, por el contrario, les basta con su inscripción en el Registro de ONGDs, como se ha llegado a mantener - no sin contradicciones- por la propia Administración. Por otro, se analiza si la inscripción en dicho Registro constituye una «condición indispensable» para que puedan disfrutar de los aludidos beneficios (como disponía la Ley 23/1998, de 7 de julio, respecto de los establecidos en la Ley 30/1994 —que anteriormente regulaba el régimen fiscal de las entidades sin fin de lucro- ), o si, distintamente, se trata de una exigencia que, tras la Ley 49/2002, ya no cabe mantener. A este debate se ha añadido el último reglamento del Registro de ONGDs, aprobado en 2015, que ha abierto nuevos frentes de polémica, por cuanto incurre en ciertos excesos en relación al concepto de ONGD, su accesibilidad a dicho registro o la suficiencia o no de su inscripción en otros.

Palabras clave: Organizaciones no gubernamentales de desarrollo - Régimen fiscal de las Entidades sin fin de lucro - Asociaciones - Utilidad Pública - Registro de Organizaciones no gubernamentales de desarrollo.

Abstract: This paper examines, on the one hand, the question of whether, in the specific case of non-governmental development organizations (NGDOs) set up as associations, it is necessary for them to be declared to be of public utility in order to be considered "non-profit entities" and enjoy the benefits recognized by Law $49 / 2002$, of 23 December, or whether, on the contrary, it is sufficient for them to be registered in the NGDO Register, as has been maintained - not without contradiction - by the Administration itself. On the other hand, an analysis is made of whether registration in said Register constitutes an "indispensable condition" for them 
to be able to enjoy the aforementioned benefits (as provided for in Law 23/1998, of 7 July, with respect to those established in Law 30/1994 -which previously regulated the tax regime of non-profit organizations-), or whether, distinctly, it is a requirement that, after Law 49/2002, can no longer be maintained. To this debate has been added the latest regulation of the NGDO Register, approved in 2015, which has opened up new fronts of controversy, in that it incurs certain excesses in relation to the concept of NGDOs, their accessibility to the said register or the sufficiency or otherwise of their registration in others.

Keywords: Non-governmental development organizations Fiscal Regime Law for non-profit organization - Associations Public utility - Registration of non-governmental development organizations.

Recepción original: 18-6-2020

Aceptación original: 20-8-2020

\section{INTRODUCCIÓN}

Las Organizaciones no gubernamentales de desarrollo (ONGDs) constituyen, tras la mención de las fundaciones y de las asociaciones de utilidad pública, la tercera categoría de entidades seleccionadas por el Legislador fiscal para integrar el concepto de «entidad sin fin de lucro" de la Ley 49/2002 ${ }^{1}$; concepto que dicha Ley construye por una doble vía ${ }^{2}$ : por un lado, estableciendo en su artículo $2^{\circ}$ la ti-

1 Véanse los arts. 2 y 3 de la referida Ley 49/2002, de 23 de diciembre, de régimen fiscal de las entidades sin fines lucrativos y de los incentivos fiscales al mecenazgo (BOE núm. 307, de 24 de diciembre), así como, muy particularmente, los párrafos $3^{\circ}$ y $4^{\circ}$ del apartado II de su Exposición de Motivos, donde justamente se anticipa que, junto a su tributación por el Impuesto sobre Sociedades y la fiscalidad en materia de tributos locales, "el concepto de entidad sin fines lucrativos» es uno de los «tres pilares básicos» en que descansa el régimen fiscal especial aplicable a dichas entidades.

2 Señalaré antes de nada, que eran varias las alternativas que cabía manejar en punto a la delimitación del ámbito subjetivo del régimen fiscal que la Ley 49/2002 instituye. Una opción hubiera sido conformarse con señalar la tipología de entidades que considerase merecedoras de dicho régimen fiscal por entender implícito en ellas su carácter no lucrativo y altruista; esto es, habida cuenta de las exigencias que para la adopción de tales formas jurídicas ya les vienen impuestas desde otros sectores del Ordenamiento. Otra posibilidad, por el contrario, era establecer en sede tributaria los requisitos necesarios para que una entidad, prescindiendo de su forma jurídica, pudiera ser considerada "entidad sin fin de lucro» (ESFL) a efectos del disfrute de dicho régimen fiscal. Tal es la fórmula que se utiliza, por ejemplo, en el art. 20, tres, de la Ley del IVA, en relación a las «entidades o 
pología de entidades que poseen intrínsecamente las características que permiten dispensarlas un tratamiento fiscal beneficioso (v.gr., la persecución de fines de interés general, la ausencia de fin de lucro, su sometimiento al control y supervisión de la Administración...) y, por otro, mediante la exigencia de los requisitos que seguidamente establece en su artículo $3^{\circ}$, dado que no en todos los casos el régimen jurídico de las entidades mencionadas en el art. $2^{\circ}$ asegura su presencia en los niveles e intensidad requeridos por el Legislador fis$\mathrm{Cal}^{3}$; todo ello, con el designio de que las que puedan gozar de la consideración de «entidad sin fin de lucro», por reunir los requisitos de forma y de fondo establecidos en los aludidos preceptos y haberse acogido a la opción que les brinda a ese propósito su artículo 14, disfruten del régimen fiscal especial que diseña en su título $\mathrm{II}^{4}$, así como, en otro plano ya, para que las que gocen de esa condición no sólo obtengan un trato privilegiado en lo que concierne a su propia tributación, sino que se beneficien también de los incentivos al mecenazgo contenidos en su título III, estimulando la financiación privada de

establecimientos de carácter social». Sin embargo, ninguna de las dos opciones convencerían al Legislador, que, a pesar de las críticas otrora vertidas con motivo de la tramitación parlamentaria de la anterior Ley de Fundaciones y de incentivos fiscales a la participación privada en actividades de interés general (Ley 30/1994, de 24 noviembre, BOE núm. 282, de 25 noviembre), terminaría acudiendo a una fórmula ecléctica, semejante - aunque no exactamente igual — a la establecida por aquélla en sus arts. 41 y 42. Así pues, de análogo modo que su predecesora, la Ley 49/2002 combinará las dos opciones a que nos hemos referido.

3 Dichos requisitos vienen a desempeñar, en este sentido, la función de cláusula de salvaguarda fiscal ante eventuales criterios que, desviándose de las pautas en atención a las cuales se instituye este régimen tributario, pudieran mantenerse, bien por los protectorados, bien por los órganos legislativos y ejecutivos de las CCAA, que, a la sazón, ostentan competencias en materia de fundaciones y asociaciones y también, en los términos que luego se verán, en el ámbito de la cooperación internacional al desarrollo. Recordaré que el propio legislador admite en el preámbulo de esta Ley que «la justificación de estos requisitos obedece a la intención de asegurar que el régimen fiscal especial que se establece para las entidades sin fines lucrativos se traduce en el destino de las rentas que obtengan a fines y actividades de interés general» (E. de M., apdo. II, pfo. $6^{\circ}$ ).

4 Nótese que el régimen establecido en la Ley 49/2002 es un régimen de acogimiento voluntario. El referido art. 14.1, en sintonía con lo anunciado en su Exposición de Motivos (párrafos $5^{\circ}$ y último de su apartado II y párrafo $2^{\circ}$ de su apartado IV), dispone a la sazón que «Las entidades sin fines lucrativos podrán acogerse al régimen fiscal especial establecido en este Título en el plazo y en la forma que reglamentariamente se establezca». Por consiguiente, aquéllas que no quieran o no puedan acogerse a dicho régimen por no reunir los requisitos más estrictos que éste comporta habrán de tributar por el régimen de las entidades parcialmente exentas del Impuesto sobre Sociedades, contenido hoy en el capítulo XIV del título VII de la Ley 27/2014, de 27 de noviembre, del Impuesto sobre Sociedades (en lo sucesivo, LIS-2014), salvo que no puedan reputarse tampoco como entidades o instituciones sin ánimo de lucro, en cuyo caso habrán de tributar como cualesquiera otra entidad por el régimen general de dicho Impuesto. 
sus actividades a través del endulzamiento de la situación tributaria de sus benefactores ${ }^{5}$.

Pero si nos hemos referido a la forma en que el legislador fiscal ha edificado el concepto de entidad sin fin de lucro es para subrayar dos importantes aspectos. El primero, que el hecho de que su construcción se haya producido partiendo de unas realidades previamente «juridificadas», esto es, ya acotadas y definidas por otros sectores del Ordenamiento, que la norma fiscal, en un primer momento, selecciona en mérito de las características con que aparecen investidas según la norma civil o administrativa (ésta sería, como hemos dicho, la labor del art. $2^{\circ}$ de la Ley 49/2002) y sobre la cual, posteriormente, actúa perfilando aquellos rasgos o caracteres que estima esenciales a los efectos de la noción que le interesa establecer (función que cumpliría el art. $3^{\circ}$ de la referida Ley), supone que sus requisitos y condiciones no pueden interpretarse desde la sola perspectiva del régimen jurídico civil o administrativo que corresponda individualmente a cada una de las figuras inicialmente consideradas. Dicho en breve: el régimen de la Ley 49/2002 no es el régimen fiscal de las fundaciones, de las asociaciones de utilidad pública, de las ONGDs... es el régimen fiscal de las «entidades sin fin de lucro». Son éstas, en rigor, los auténticos «sujetos» de dicho régimen, aunque por comodidad expositiva nos refiramos a cada una de las mencionadas en su artículo $2^{\circ}$ como si lo fueran. Por consiguiente, será el Derecho tributario el llamado, en primer término, a resolver los problemas interpretativos que presente esta categoría, en cuanto propia de dicho sector del Ordenamiento.

$\mathrm{Y}$, segundo, que el contenido del repetido artículo $2^{\circ}$ no constituye una mera lista inconexa de entidades. No es un «cajón de sastre», si se me permite expresarlo coloquialmente. En cuanto constituye el resultado de una selección en la que el Legislador ha tomado en cuenta la «función social, actividades y características» de las entidades escogidas ${ }^{6}$, la consideración de todas ellas como conjunto nos ofrece un patrón de los rasgos y perfiles jurídicos comunes que, juntamente con los requisitos del artículo $3^{\circ}$, constituye una guía in-

5 En este sentido, la Ley 49/2002 dispondrá:

"Artículo 16. Entidades beneficiarias del mecenazgo. Los incentivos fiscales previstos en este Título serán aplicables a los donativos, donaciones y aportaciones que, cumpliendo los requisitos establecidos en este Título, se hagan en favor de las siguientes entidades:

a) Las entidades sin fines lucrativos a las que sea de aplicación el régimen fiscal establecido en el Título II de esta Ley.

$[\ldots] »$.

6 Artículo 1.1 de la Ley 49/2002. 
terpretativa que nos permitirá resolver los problemas hermenéuticos que plantean supuestos como al que ahora hemos de enfrentarnos, porque, en efecto - y con ello entramos ya en el asunto de que aquí nos ocuparemos-, la inclusión de las ONGDs en el artículo 2.c) de la Ley 49/2002, en el modo en que se hizo, no ha sido, desde luego, muy afortunada: en la medida en que se efectúa con la especificación de que han de tener "alguna de las formas jurídicas a que se refieren los párrafos anteriores» (en los cuales, como acabamos de ver, se menciona a las fundaciones y a las asociaciones declaradas de utilidad pública), la interpretación sobre su alcance y significado se ha visto, desde un principio, rodeada de polémica. En realidad, siendo rigurosos, la cuestión que suscita dicho precepto ni siquiera es nueva: ya durante la vigencia de su predecesora, la Ley 30/1994, se produciría una situación casi idéntica con motivo de la aprobación de la Ley 23/1998, de 7 de julio, de Cooperación Internacional para el Desarrollo ${ }^{7}$, cuyo art. 35.1, análogamente que el art. 2.c) de la Ley 49/2002, señalaba que las ONGDs inscritas en los Registros a que se refiere su artículo 33 podrían disfrutar del régimen tributario de las entidades sin fines lucrativos, pero siempre que revistiesen la forma jurídica y cumplieran los requisitos exigidos en el capítulo I del Título II de la Ley 30/1994, lo que reenviaba directamente al art. 41 de dicha Ley, que principiaba el capítulo I de su Título II circunscribiendo el régimen fiscal a «las fundaciones inscritas en el Registro correspondiente y a las asociaciones declaradas de utilidad pública».

Se ha de recordar que, a diferencia de otras entidades que se recogían en las disposiciones adicionales de la Ley 30/1994 permitiéndose que disfrutaran del régimen tributario previsto en su título II, como sería el caso de las federaciones deportivas ${ }^{8}$, del Comité Olímpico Español ${ }^{9}$, de las federaciones y asociaciones de entidades sin fin de lucro ${ }^{10}$ o de las fundaciones extranjeras ${ }^{11}$ — todas ellas, por cierto, contempladas hoy en los distintos apartados del art. $2^{\circ}$ de la Ley 49/2002-, las ONGDs, en cambio, no serían expresamente mencionadas como tales en la Ley 30/1994, por lo que, claramente, sólo podían disfrutar de dicho régimen fiscal en tanto en cuanto fuesen fundaciones o asociaciones de utilidad pública y cumplieran los requisitos exigidos en la misma, conforme establecía el art. 41 de la citada Ley. El problema, pues, se plantearía a raíz de la Ley 23/1998, mas no tanto por lo que decía —o cabría pensar que decía, según

7 BOE núm. 162, de 8 de julio de 1998.

8 Disposición Adicional Duodécima de la citada Ley 30/1994.

9 Ibidem

10 Disposición Adicional Decimoquinta.

11 Disposición Adicional Decimosexta. 
luego estudiaremos-, como por la manera en que lo expresaba: que revistieran la forma jurídica...; problema que, como estamos viendo, mantiene y duplica la Ley 49/2002 al utilizar análoga dicción.

En efecto, adviértase que si las únicas ONGDs que pueden disfrutar del régimen especial de las entidades sin fin de lucro son las que sean fundaciones o asociaciones de utilidad pública, su mención inmediatamente después de haber contemplado ya a dicho tipo de entidades resulta un tanto sorprendente y autoriza a interrogarse, con razón, cuál pudo haber sido el propósito que animase al Legislador - por dos veces - a incurrir en tal aparente redundancia, si es que verdaderamente la hay, porque la referencia a «la forma jurídica», que, como venimos diciendo, es la expresión utilizada tanto por la Ley 23/1998 como por la Ley 49/2002, da pábulo a una interpretación que, atendiendo a la literalidad del art. 2.c), salva ese reproche, sí, pero alimentando el debate sobre si las ONGDs «con forma de asociación» deben contar con la declaración de utilidad pública para poder alcanzar la condición de entidades sin fin de lucro a efectos de la Ley 49/2002 o si, por el contrario, les es suficiente - y necesario: otro aspecto no exento tampoco de polémica- con figurar inscritas en el Registro de ONGDs, amén de estarlo en el que proceda conforme a su naturaleza jurídica ${ }^{12}$.

12 En la doctrina se han referido a estas cuestiones, entre otros, GIL DEL CAMPO, M.: Fiscalidad de fundaciones, asociaciones y del mecenazgo, CISS, Valencia, 2003, págs. 111-112, considerando necesario que las ONGDs con forma de asociación obtuvieran la declaración de utilidad pública; y, posteriormente, el mismo autor, en Contabilidad y Fiscalidad de las entidades sin fines lucrativos y del mecenazgo, CISS, Madrid, 2010, págs. 143-144, pero en sentido contrario, a la vista del criterio de la Dirección General de Tributos, partidaria, según indicaba, de que se les aplicase el régimen de la Ley 49/2002 aun cuando no hayan obtenido dicha declaración, citando en tal sentido la resolución de la DGT de 22 de enero de 2009 (en referencia a la que da contestación a la consulta V0126-09). Asimismo se ha ocupado del tema: Pedreira Menéndez, J.: El Régimen Fiscal del Sector No Lucrativo y del Mecenazgo. Comentarios a la Ley 49/2002, de 23 de diciembre, de Régimen fiscal de las entidades sin fines lucrativos y de los incentivos fiscales al mecenazgo, Civitas, Madrid 2003, pág. 76, quien consideraría que, a diferencia de lo que hubiera sucedido de aprobarse la redacción original del Proyecto de Ley, dada la letra final del artículo 2.c) de la Ley 49/2002, la declaración de utilidad pública resulta necesaria, salvo en Navarra, recordando que, en dicha Comunidad, si bien la Ley Foral 19/1999, de 30 de diciembre, de medidas tributarias, extendió, desde el 1 de enero de 2000, el régimen fiscal de las fundaciones a las ONGDs, siempre que éstas tuvieran la forma jurídica de fundación o asociación declarada de utilidad pública [he de apostillar que, en rigor, dicha exigencia, al igual que en la Ley estatal 30/1994, ya se encontraba inicialmente establecida en la DA $2^{\text {a }}$ de la Ley Foral 10/1996, de 2 de julio, reguladora del régimen tributario de las fundaciones y de las actividades de patrocinio, en relación a su art. 2.b)], más tarde, el art. 22 de la posterior Ley Foral 5/2001, de 9 de marzo, de Cooperación al desarrollo, concedería dicho régimen fiscal a todas las ONGDs inscritas, ahora ya independientemente de 
Controversia a la que se añade hoy el último reglamento del Registro de ONGDs de $2015^{13}$, que, lejos de despejar las incertidumbres, abre nuevos frentes de discrepancia, por cuanto, como seguidamente tendremos ocasión de estudiar, incurre en ciertos excesos en relación al concepto de ONGD.

su forma jurídica. Vid. PedreIRA, ibidem, nota 111. No obstante, he de añadir por mi parte que el rumbo de la legislación navarra sobre este punto sería extremadamente vacilante, porque, con posterioridad, el art. 8, Cuatro, de la Ley Foral 19/2005, de 29 de diciembre, de modificación de diversos impuestos y otras medidas tributarias, daría nueva redacción a la aludida DA $2^{\text {a }}$ de la Ley Foral 10/1996, volviendo a exigir que las ONGDs tuvieran la «forma jurídica de fundación o de asociación declarada de utilidad pública». No sería el último cambio. La Disposición final $3^{\text {a }}$ de la Ley Foral 4/2010, de 6 de abril, por la que se modificaba la citada Ley Foral 5/2001, de Cooperación al Desarrollo, alteraría nuevamente la redacción de la DA $2^{\text {a }}$ de la Ley 10/1996, manteniendo la exigencia de que tengan la forma jurídica de fundación o de asociación, pero eliminando la referencia a la utilidad pública en el caso de las ONGDs con forma de asociación. Regresando al ámbito doctrinal y a la Ley 49/2002, se pronunciarían en el sentido de estimar necesario que las ONGDs con forma de asociación estuvieran declaradas de utilidad pública: LóPez Ribas, S.: "Estatuto fiscal del mecenazgo en la Ley 49/2002», Quincena Fiscal, no 5/2004 (BIB 2004\213), nota 6; y CRUZ AMORós, M. y LóPEZ RiBAS, S.: La fiscalidad en las entidades sin fin de lucro: estímulo público y acción privada. CIDEAL-PricewaterhouseCoopers, Madrid, 2004, pág. 16. En cambio, distinto criterio, invocando la resolución de la DGT de 18 de enero de 2006 (V0098-06), es el que mantuvo Montesinos Oltra, S. en «Los requisitos del régimen tributario especial de las entidades sin fines lucrativos». Cuadernos de Aranzadi Jurisprudencia Tributaria, núm. 49, 2008, § IV. 2.3 (BIB 2008\554). Por su parte, mostrándose a favor de que deban obtener la declaración y señalando la discriminación que de otro modo se produciría: Blázouez Lidoy, A. y Martín Dégano, I.: Manual tributario de entidades no lucrativas (asociaciones y fundaciones). Centro de Estudios Financieros, Madrid, 2012, págs. 29-31. Diferente postura, indicando que la intención de legislador fue la de exigir la declaración de utilidad, pero postulando de lege ferenda su eliminación: Vidal Wagner, De URRUTIa Coduras y Esquerra Miramunt, en AA.VV., "Las Organizaciones no gubernamentales con forma jurídica de asociación, ¿necesidad de ser declaradas de "utilidad pública"? Posibilidad de revisar la exigencia de la declaración de utilidad pública», Fiscalidad del mecenazgo, edit. Fundación Impuestos y Competitividad, Madrid, 2017, págs. 235-317; y, también más recientemente, pero en sentido inverso, recordando que se las colocaría en una situación de privilegio que solo podría justificarse si se las sometiese a algún tipo de control análogo al de las declaradas de utilidad pública, MARTín DÉGANO, I.: «La situación actual de los incentivos fiscales al mecenazgo en la legislación estatal. Reflexiones a futuro», en AA.VV. (dir. CABRA DE LUNA, M.A.), La dimensión social de la fiscalidad: discapacidad, tercer sector y mecenazgo. Estudios en homenaje a Miguel Cruz Amorós, CERMI, Madrid, 2017, págs. 215-239.

13 Dicho nuevo Reglamento sería aprobado por el Real Decreto 193/2015, de 23 de marzo (BOE núm. 83, de 7 de abril), que derogaba y sustituía el anterior, aprobado por Real Decreto 993/1999, de 11 de junio (BOE núm. 152, de 26 de junio). 


\section{LAS ORGANIZACIONES NO GUBERNAMENTALES DE DESARROLLO}

La Ley 23/1998 — que es a la que específicamente remite el art. 2.c) de la Ley 49/2002 para concretar el tipo de sujetos susceptibles de considerarse a su amparo entidades sin fin de lucro- contempla a las ONGDs en su capítulo VI como uno de los cauces de la «participación social» más característicos y emblemáticos de la cooperación no gubernamental, singularizándolas entre un variado conjunto de actores (entre los que la propia Ley expresamente mencionará a las universidades, las empresas, las organizaciones empresariales y los sindicatos $)^{14}$, disponiendo su inclusión en un registro ad hoc, en contraste con otros textos legislativos que, sin perjuicio de efectuar el mismo reconocimiento, optarán, no obstante, por un enfoque global y la inscripción de los distintos agentes de la cooperación en un mismo censo ${ }^{15}$. En esa labor de identificación de las organizaciones de la sociedad civil comprometidas en este campo, el art. 32.1 de la Ley 23/1998 definirá a las ONGDs como «aquellas entidades de Derecho privado, legalmente constituidas y sin fines de lucro, que tengan entre sus fines o como objeto expreso, según sus propios Estatutos, la realización de actividades relacionadas con los principios y objetivos de la cooperación internacional para el desarrollo", inclinándose, pues, por una fórmula relativamente abierta, donde, prescindiendo de la forma que puedan haber adoptado, prima el criterio teleológico, tanto en sentido negativo, para excluir aquellas que per-

14 Vid. el art. 31 de dicha Ley 23/1998. Otras leyes autonómicas como, por ejemplo, la Ley Valenciana 18/2017, de 14 de diciembre, de cooperación y desarrollo sostenible (BOE núm. 4, de 4 de enero de 2018) añadirán a dicha lista, también de forma no exhaustiva, una extensa panoplia de agentes de la cooperación internacional al desarrollo tanto de naturaleza pública como privada y tanto de carácter nacional como internacional. Así, mencionará a las entidades locales de la Comunidad Valenciana y demás entidades públicas vinculadas a ellas; a las agencias de Naciones Unidas y sus comités nacionales u organizaciones que las representen en España o a las organizaciones e instituciones internacionales de cooperación internacional al desarrollo, con exclusión — precisa- de las instituciones financieras internacionales (cfr. art. 21.3 de la referida Ley 18/2017).

15 Es el caso, por citar algún ejemplo, de la Ley Andaluza 14/2003, de 22 de diciembre, de Cooperación Internacional para el Desarrollo (BOE núm. 14, de 16 de enero de 2004), arts. 17, 19 y 20, y del correlativo Decreto núm. 172/2005, de 19 de julio, por el que, entre otros órganos, se regula el «Registro de agentes de la cooperación internacional para el desarrollo en Andalucía» (BOJA núm. 142, de 22 de julio), arts. 16 a 30. En el mismo sentido, pueden verse también los artículos 21, 22 y 25 de la ya citada Ley Valenciana 18/2017 (y, anteriormente, la Ley 6/2007, de 9 de febrero, de cooperación al desarrollo de la Comunitat Valenciana), así como el Decreto 39/2009, de 6 marzo, por el que se regula el Registro Agentes de la Cooperación Internacional al Desarrollo de dicha Comunidad (DOGV núm. 5971, de 10.03.2009).

(C) UNED. Revista de Derecho UNED, núm. 27, 2021 
sigan fines lucrativos, como positivo, para comprender las que estatutariamente, y no de manera puramente accidental, tengan como finalidad su actuación en dicho ámbito ${ }^{16}$.

A ese respecto, el artículo 1.1 de dicha Ley señalará en su apartado segundo que "se integran dentro de la cooperación internacional para el desarrollo el conjunto de recursos y capacidades que España pone a disposición de los países en vías de desarrollo con el fin de facilitar e impulsar su progreso económico y social, y para contribuir a la erradicación de la pobreza en el mundo en todas sus manifestaciones», concretando en su párrafo tercero que "La cooperación española impulsará procesos de desarrollo que atiendan a la defensa y protección de los Derechos humanos y las libertades fundamentales, las necesidades de bienestar económico y social, la sostenibilidad y regeneración del medio ambiente, en los países que tienen elevados niveles de pobreza y en aquellos que se encuentran en transición hacia la plena consolidación de sus instituciones democráticas y su inserción en la economía internacional». Ello es detallado luego en la Sección II del capítulo I, a la sazón titulada «Principios, objetivos y prioridades de la política española de cooperación internacional», en cuyo art. 3, para su logro en el marco de los principios formulados en el artículo $2^{17}$, enuncia los siguientes objetivos:

16 Algunos autores han reprochado que el concepto de ONGD del art. 32.1 de la Ley 23/1998, pese a exigir que se trate de organizaciones privadas sin ánimo de lucro, está redactado, a su juicio, con tal falta de precisión que podrían caber dentro del mismo desde entidades constituidas de acuerdo con el derecho privado, pero participadas total o parcialmente por entidades públicas, hasta sociedades con forma mercantil, dado que «de acuerdo con la doctrina dominante, [el ánimo de lucro] no es un requisito esencial de las sociedades mercantiles» [cfr., GIL DEL CAMPO, M. (Contabilidad y Fiscalidad de las entidades sin fines lucrativos y del mecenazgo, CISS, Madrid, 2010, pp. 139 y ss.].

17 Dicho artículo 2 dispone:

«Artículo 2. Principios. La política española de cooperación internacional para el desarrollo, inspirada en la Constitución, expresa la solidaridad del pueblo español con los países en desarrollo y, particularmente, con los pueblos más desfavorecidos de otras naciones y se basa en un amplio consenso político y social a escala nacional, de acuerdo con los siguientes principios:

a) El reconocimiento del ser humano en su dimensión individual y colectiva, como protagonista y destinatario último de la política de cooperación para el desarrollo.

b) La defensa y promoción de los Derechos humanos y las libertades fundamentales, la paz, la democracia y la participación ciudadana en condiciones de igualdad para mujeres y hombres y, en general, la no discriminación por razón de sexo, raza, cultura o religión, y el respeto a la diversidad.

c) La necesidad de promover un desarrollo humano global, interdependiente, participativo, sostenible y con equidad de género en todas las naciones, procurando la aplicación del principio de corresponsabilidad entre los Estados, en orden a asegurar y potenciar la eficacia y coherencia de las políticas de cooperación al desarrollo en su objetivo de erradicar la pobreza en el mundo. 
«a) Fomentar con recursos humanos y materiales el desarrollo de los países más desfavorecidos para que puedan alcanzar un crecimiento económico con un reparto más equitativo de los frutos del desarrollo, favoreciendo las condiciones para el logro de un desarrollo autosostenido a partir de las propias capacidades de los beneficiarios, propiciando una mejora en el nivel de vida de las poblaciones beneficiarias, en general, y de sus capas más necesitadas, en particular, y promoviendo mayores garantías de estabilidad y participación democrática en el marco del respeto a los derechos humanos y las libertades fundamentales de mujeres y hombres.

b) Contribuir a un mayor equilibrio en las relaciones políticas, estratégicas, económicas y comerciales, promoviendo así un marco de estabilidad y seguridad que garantice la paz internacional.

c) Prevenir y atender situaciones de emergencia mediante la prestación de acciones de ayuda humanitaria.

d) Favorecer la instauración y consolidación de los regímenes democráticos y el respeto de los derechos humanos y de las libertades fundamentales.

e) Impulsar las relaciones políticas, económicas y culturales con los países en vías de desarrollo, desde la coherencia con los principios y demás objetivos de la cooperación ${ }^{18}$.

d) La promoción de un crecimiento económico duradero y sostenible de los países acompañada de medidas que promuevan una redistribución equitativa de la riqueza para favorecer la mejora de las condiciones de vida y el acceso a los servicios sanitarios, educativos y culturales, así como el bienestar de sus poblaciones.

e) El respeto a los compromisos adoptados en el seno de los Organismos internacionales».

18 Los objetivos transcritos serán especificados luego, desde el prisma de su prioridad tanto geográfica como sectorial, en los artículos 6 y 7 de la repetida Ley, así como, desde el punto de vista de los instrumentos, en el art. 9 y siguientes. Vid., infra, nota 80 .

Por su parte, en coherencia con lo anterior, la Ley 2/2014, de 25 de marzo, de la Acción y del Servicio Exterior del Estado (BOE núm. 74, de 26 de marzo), al referirse a la cooperación internacional al desarrollo como uno de los ámbitos de la Acción Exterior del Estado, señalará en su artículo 24 que «La Acción Exterior en materia de cooperación para el desarrollo se orientará a contribuir a la erradicación de la pobreza, al desarrollo humano sostenible y al pleno ejercicio de los derechos, mediante la consolidación de los procesos democráticos y el Estado de Derecho, la reducción de las desigualdades, el fomento de los sistemas de cohesión social, 
Por consiguiente, sin perjuicio de lo que después habremos de precisar a propósito de la reforma del Registro de ONGDs, puede afirmarse que, con arreglo a la Ley 23/1998, aquellas entidades privadas sin fin de lucro que estatutariamente tengan entre sus fines $o$ como objeto expreso la realización de actividades relacionadas con los principios y objetivos anteriormente mencionados habrían de ser consideradas ONGDs ${ }^{19}$.

En efecto, nótese que para su consideración como ONGDs la Ley 23/1998 no las impone una forma jurídica concreta - a diferencia de la Ley 49/2002 —20 , requiriendo, simplemente, que gocen de plena ca-

la promoción de los derechos de las mujeres y la igualdad de género; dando una respuesta de calidad a las crisis humanitarias».

19 Es oportuno recordar a este respecto que en su tramitación parlamentaria fue rechazada la enmienda núm. 186, presentada por el Grupo Parlamentario Socialista, que les imponía requisitos mucho más amplios. Así, dicha enmienda propondría la siguiente redacción del art. 28 del Proyecto (art. 32 de la Ley):

«A los efectos de la presente Ley, tendrán la consideración de Organizaciones No Gubernamentales de Desarrollo (ONGDs) aquellas entidades que reúnan los requisitos siguientes:

a) Tener como fines institucionales expresos la realización de actividades relacionadas con la Cooperación para el Desarrollo, el fomento de la solidaridad entre los pueblos, la ayuda humanitaria, así como las iniciativas del movimiento denominado de "Comercio Justo y Consumo Responsable" y de la Educación para el Desarrollo.

b) Estar constituidas legalmente.

c) Gozar de plena capacidad jurídica y de obrar.

d) Carecer de ánimo de lucro.

e) Disponer de recursos tanto humanos como materiales o económicos procedentes de la solidaridad, donaciones privadas y trabajo voluntario.

f) Acreditar la estructura suficiente para garantizar el cumplimiento de sus objetivos, con la experiencia en cooperación y capacidad operativa necesaria para ello.

g) Los Estatutos de las ONGDs que sean reconocidas como tales, deberán establecer mecanismos transparentes y participativos de elección o nombramiento de sus cargos representativos.»

Vid. BOCG, VI Legislatura, serie A, núm. 81-7, de 17 de noviembre de 1997, enmienda núm. 186, pág. 105.

Tampoco prosperaría la enmienda núm. 29, formulada por el Grupo Parlamentario IU-IC, en el sentido, básicamente, de añadir a los del Proyecto los requisitos de «estar al día en sus obligaciones fiscales y con la Seguridad Social, y demostrar la suficiente estructura y medios para desarrollar sus programas", proponiendo, asimismo, que para la financiación de sus proyectos con fondos públicos, y en base al principio de corresponsabilidad, las ONGDs deberían aportar sus recursos propios en la cuantía que la AECID [Agencia Española de Cooperación Internacional para el Desarrollo, véase más adelante nota 23] exigiera en cada caso. Vid. BOCG, VI Legislatura, serie A, núm. 81-7, de 17 de noviembre de 1997, enmienda núm. 29, pág. 32 .

20 Así, por ejemplo, una cooperativa calificada como «entidad sin fines lucrativos» según lo previsto en la DA $1^{\text {a }}$ de la Ley 4/1999, de 30 marzo, de Cooperativas de la Comunidad de Madrid (BOCM núm. 87, de 14 de abril; BOE núm. 131, de 2 de junio) y que se dedique a la cooperación internacional para el 
pacidad jurídica y de obrar y que dispongan de una "estructura susceptible de garantizar suficientemente el cumplimiento de sus objetivos» (art. 32.2); condición, esta última, que se presta, no obstante, a muy diversas interpretaciones, al punto de que algunas, como posteriormente tendremos ocasión de comprobar, producen una severa restricción del concepto legal al inferir de la misma la necesidad de que reúnan una serie de requisitos organizativos, de solvencia, de continuidad, de diligencia fiscal, de independencia..., tal vez, más propios de las condiciones de las bases de una convocatoria de ayudas o subvenciones que de los requisitos para que pueda considerárselas $\mathrm{ONGDs}^{21}$.

desarrollo - como expresamente se contempla en dicha disposición-, entraría en el concepto de ONGD y, teóricamente, podría acceder al correspondiente Registro de ONGDs y disfrutar de ayudas y subvenciones computables como ayuda oficial al desarrollo (art. 33.2 de la Ley 23/1998). Sin embargo, prima facie, debido a su forma jurídica, quedaría fuera del ámbito de aplicación del régimen fiscal de la Ley 49/2002, por mor de lo dispuesto en el último inciso de su art. 2.c). Así lo ha venido manteniendo la DGT en contestaciones a las consultas vinculantes núms. V179105, de 16/09/2005 y V1457-12, de 04/07/2012, a pesar de lo que prescribe al efecto la citada Disposición Adicional. Recordaré que la misma establece:

«Disposición adicional primera. Calificación como entidad sin fines lucrativos.

Las cooperativas que persigan fines de asistencia social, cívicos, educativos, culturales, científicos, deportivos, sanitarios, de cooperación para el desarrollo, de defensa del medio ambiente, de fomento de la economía social o de la investigación, de promoción del voluntariado social, o cualesquiera otros fines de interés general de naturaleza análoga podrán solicitar del Registro de Cooperativas, la calificación de entidad sin fines lucrativos a los efectos de ser beneficiarias del régimen tributario de las entidades sin fines lucrativos, calificación que le será otorgada siempre y cuando cumplan los requisitos establecidos para las cooperativas de iniciativa social a que se refiere el artículo 107 de esta Ley».

Ahora bien, es importante apostillar a este respecto que, a la luz de la jurisprudencia del TC, para considerar que la disposición autonómica transcrita resulta ajustada al bloque de la constitucionalidad ha de interpretarse en el sentido de que dicha calificación sólo resulta aplicable en relación a los tributos competencia de la mencionada Comunidad Autónoma. En este sentido, por todas, SSTC 176/1999, de 30 de septiembre (FJ 4), y 74/2000, de 16 de marzo (FJ 3).

21 En este sentido, aunque no se trata propiamente de un requisito para ser consideradas ONGDs, sino para poder registrarse como tales, cabe señalar, por ejemplo, que entre la documentación que conforme al nuevo Reglamento del Registro de ONGDs debe acompañarse a la solicitud de inscripción en el mismo, el art. 7.1.e), párrafo último, de análogo modo que la Ley General de Subvenciones [vid. su art. 13, apartado 2, letras g) y e)] exige que se presente una declaración responsable en la que, entre otras menciones, haga referencia a hallarse al corriente en el cumplimiento de sus obligaciones tributarias, con la seguridad social y por reintegro de subvenciones, disponiéndose en el apartado 2 de dicho mismo precepto que los solicitantes podrán autorizar a la AECID para que recabe los datos relativos a algunos de los documentos exigidos y a comprobar que la entidad se encuentra al corriente en el cumplimiento de dichas obligaciones, quedando en tal caso eximidos de la necesidad de aportarlos. Adviértase que con ello una organización que indiscutiblemente se dedique a la cooperación al desarrollo, pero que, por 
En todo caso, lo que sí previene la Ley, en su art. 33, es que dichas organizaciones puedan inscribirse -incluso, como luego se explicará, que, a ciertos efectos, «deban» inscribirse- en el Registro de organizaciones no gubernamentales de desarrollo abierto en la Agencia Española de Cooperación Internacional (hoy, Agencia Española de Cooperación Internacional para el Desarrollo, en adelante, AECID ${ }^{22}$, admitiéndose también, sin perjuicio de lo que luego se

ejemplo, tenga deudas tributarias pendientes, no podría acceder al Registro de ONGDs, impidiéndola así, según cierta lectura (vid., supra, apdo. IV), no sólo gozar de las ayudas y subvenciones computables a efectos de la AOD, sino también - a diferencia de otras ESFL con diferente objeto, a las que no se las exige estar al corriente de tales obligaciones para poder acogerse al régimen de la Ley 49/2002 - el que puedan tener acceso a los beneficios fiscales propios de dicho régimen, privándolas asimismo del derecho a la publicidad que pueda proporcionar su inscripción en el repetido Registro.

No obstante, en este aspecto convendrá anotar el paralelismo $-\mathrm{y}$ no será la única coincidencia- entre el citado art. 7 del Reglamento del RONGDs y el art. 2 del Real Decreto 1740/2003, de 19 de diciembre, sobre procedimientos relativos a asociaciones de utilidad pública, que contiene la misma exigencia, lo que abona la polémica sobre la suficiencia de su inscripción en este Registro versus la necesidad de estar, además, declaradas de utilidad pública en el caso de las asociaciones. Pero sobre dicha cuestión posteriormente volveremos en el texto.

22 La Agencia Española de Cooperación Internacional para el Desarrollo (AECID) tiene su antecedente en el Organismo autónomo de análogo nombre (Agencia Española de Cooperación Internacional), que fue creado por el art. 4 del Real Decreto 1527/1988, de 11 de noviembre (BOE núm. 307, de 23 diciembre) mediante la refundición e integración de los extinguidos organismos autónomos Instituto de Cooperación Iberoamericana e Instituto Hispano-Árabe de Cultura, la Oficina de Cooperación con Guinea Ecuatorial y algunas unidades de la Dirección General de Cooperación Técnica Internacional. No estará de más recordar que en aquellos años hacía poco que España había dejado de ser considerada país receptor de ayudas internacionales al desarrollo; situación en que se había mantenido hasta 1981, según se hace notar en la Exposición de Motivos de la Ley 23/1998, aunque ya durante la década anterior se había comenzado una incipiente política de cooperación. Posteriormente, el Real Decreto 2492/1994, de 23 de diciembre (BOE núm. 9, de 11 de enero de 1995) y, luego, los Reales Decretos núm. 1141/1996, de 24 de mayo (BOE núm. 127, de 25 de mayo) y núm. 1870/1998, de 4 de septiembre (BOE núm. 217, de 10 de septiembre), reestructurarían el Organismo, remodelando sus órganos de gobierno, que pasaron a vertebrarse en torno a un Presidente, un Secretario general ejecutivo y un Comité de Dirección. Su estatuto, de conformidad con lo previsto en el art. 25.4 de la Ley 23/1998, sería aprobado por el Real Decreto 3424/2000, de 15 de diciembre (BOE núm. 301, de 16 diciembre). Pero su creación formal como Agencia estatal se produciría más tarde, al amparo de la DA $3^{\text {a }}$ de la Ley 28/2006, de 18 de julio, de Agencias Estatales para la mejora de los servicios públicos, por medio del Real Decreto 1403/2007, de 26 de octubre (B.O.E. núm. 283 de 26 de noviembre, c.e. B.O.E. núm. 41, de 16.02.2008), en el que quedaría aprobado su Estatuto actual.

De acuerdo con su artículo 1, la AECID es una entidad de derecho público de las previstas en el artículo 2 de la citada Ley 28/2006, adscrita al Ministerio de Asuntos Exteriores, Unión Europea y Cooperación (en su denominación actual) a través de la Secretaría de Estado de Cooperación Internacional [hoy, Secretaría de Estado de 
dirá, que puedan hacerlo en los registros que con idéntica finalidad puedan crearse en las CCAA. En tal sentido, el art. 33 de la citada Ley establece en su apartado 1, párrafo segundo, que se articularán los correspondientes procedimientos de colaboración entre dicha Agencia y las CCAA, a fin de asegurar la comunicación y homologación de los datos registrales.

No obstante, antes de proseguir, será oportuno efectuar ya algunas anotaciones preliminares sobre las ONGDs y su inscripción - o mejor dicho, sobre los efectos de la ausencia de inscripción- en los referidos Registros, tanto por lo que concierne a su propia consideración como ONGDs, como respecto del acceso a los beneficios fiscales del régimen de la Ley 49/2002 — que es de lo que aquí se trata-, principiando todo ello con las oportunas referencias al reparto competencial entre el Estado y las CCAA y a la actual regulación del Registro de la AECID, imprescindibles para la recta comprensión de dicha problemática.

\section{EL REGLAMENTO DEL REGISTRO DE ONGDS DE 2015 Y LA RESTRICCIÓN DEL CONCEPTO DE ONGD.}

El vigente reglamento del Registro de ONGDs, como anteriormente expuse, fue aprobado por el RD 193/2015, de 23 marzo, en

Cooperación Internacional y para Iberoamérica y el Caribe], conforme a lo dispuesto en el art. 21 de dicho Estatuto, constituyendo, por excelencia, el órgano de fomento, gestión y ejecución de la política española de cooperación internacional para el desarrollo, sin perjuicio de las competencias asignadas a otros departamentos ministeriales (en particular, al Ministerio de Hacienda y al de Asuntos Económicos). Piénsese a este respecto, que no siempre se ha diferenciado - $\mathrm{o}$ se ha considerado pertinente diferenciar - la cooperación al desarrollo, stricto sensu, del fomento de la internacionalización de las empresas españolas y que no ha sido, ni es, infrecuente el condicionamiento de las ayudas a la apertura y liberalización de las economías de los países receptores. Pero ese, sin duda, es otro debate.

En cuanto al Registro de organizaciones no gubernamentales de desarrollo previsto en el citado art. 33, es un registro dependiente del Ministerio de Asuntos Exteriores, Unión Europea y Cooperación y adscrito a la AECID, que tiene por objeto censar las ONGDs que cumplan los requisitos para ser consideradas como tales. De acuerdo con el apartado 3 de dicho art. 33, el mencionado Registro tiene carácter público, en los términos establecidos en el art. 37 de la LRJPAC - hoy la referencia ha de entenderse realizada al art. 13.d) de la Ley 39/2015, de 1 de octubre, del Procedimiento Administrativo Común de las Administraciones Públicas-, habiendo sido regulado originariamente, según prevenía el apartado 1 del repetido art. 33, por el Real Decreto 993/1999, de 11 de junio, aprobatorio del Reglamento del Registro de organizaciones no gubernamentales de desarrollo (ya anteriormente citado: vid. supra nota 14), que, como se dijo, ha sido derogado y sustituido por uno nuevo, aprobado por el Real Decreto 193/2015, de 23 de marzo, cuyos aspectos problemáticos serán comentados más adelante en el texto.

(C) UNED. Revista de Derecho UNED, núm. 27, 2021 
sustitución del anterior, de $1999^{23}$, con el argumento de haberse producido desde entonces diversos «cambios en el sector y en la propia Administración General del Estado, junto con la creación de registros de la misma naturaleza en algunas CCAA», lo que, según se manifestaba en la Exposición de Motivos y en la Memoria de Análisis del Impacto Normativo que acompañara al Proyecto elaborado por el Ministerio de Asuntos Exteriores y Cooperación, hacía «ineludible» la adaptación de la regulación anterior al nuevo contexto ${ }^{24}$.

Entre otras innovaciones, el Reglamento de 2015 procedería, en lo que aquí nos interesa, a desarrollar la «somera» definición —así la calificaba- de ONGD contenida en la Ley 23/1998 y a "subsanar», según asimismo afirmaba, las omisiones de su antecesor en punto a

23 Vid. supra, nota 14.

24 Aunque en la Exposición de Motivos no se detalla, en la Memoria de Análisis del Impacto Normativo (MAIN) sí se indicaba, en relación a los «cambios en el sector», que se trataba, entre otros, del incremento de fusiones, escisiones y transformaciones de naturaleza jurídica de las entidades susceptibles de ser inscritas en dicho Registro. En análogo sentido, tanto en la referida Memoria como en la E. de M. se invocaría asimismo «[1]a evolución del sector de las ONGD, impulsada por una creciente implantación social, experiencia y profesionalización en su funcionamiento, [que] ha modificado la estructura y forma de actuar de las mismas, y ha propiciado también un aumento en su número». Vid., Portal de Transparencia de la Administración General del Estado:

<http://transparencia.gob.es/servicios-buscador/contenido/normavigente. htm?id=NormaEV06D2-20151201\&lang=es\&fcAct=2018-01-10T10:54:01.182Z > . Fecha acceso doc.: 24/09/2018.

En cuanto a los "cambios en la Administración General del Estado», también invocados como determinantes del nuevo Reglamento, ni la MAIN ni la Exposición de Motivos concretan cuáles sean y en qué consisten, lo que no ha sido obstáculo para que algunos comentaristas (entiendo que por comparación con el anterior texto reglamentario) hayan deducido que se refieren a la «lógica evolución institucional y, sobre todo, al influjo de los avances tecnológicos experimentados en materia de telecomunicaciones». Así, ROMERO GALLARDO, A.: «Cuestiones de interés sobre la información inscrita y archivada en el Registro estatal de Organizaciones No Gubernamentales de Desarrollo, a la luz de su nuevo Reglamento de 2015», en Actas das I Xornadas Olga Gallego de Arquivos. Transparencia "versus" corrupción: os arquivos e a democracia, celebradas en La Coruña los días 2 y 3 de octubre de 2015. Su texto está disponible en el sitio:

<http://fundacionolgagallego.gal/upload/recursos/cat_2/44/ponencias/24/ transparencia_1_136-154_romero.pdf;jsessionid=870A3B16ABA4459A62ED7CE 12C741769>. Fecha acceso al documento: 23/09/2018.

Finalmente, en lo que concierne a la «creación de registros de la misma naturaleza en algunas CCAA», estimo que, sin demérito de los anteriores, éste es verdaderamente el motivo decisivo y principal de su dictado, que, no casualmente, se produce en el contexto de diversos cambios legislativos dirigidos a encauzar ciertas disfunciones derivadas de la creciente actividad exterior de las CCAA: la ya citada Ley 2/2014, de 25 de marzo, de la Acción y del Servicio Exterior del Estado, y la Ley 25/2014, de 27 de noviembre, de Tratados y otros Acuerdos Internacionales (BOE núm. 288, de 28 de noviembre). 
las relaciones entre el registro de la AECID y los autonómicos ${ }^{25}$, instaurando una noción de ONGD no sólo mucho más restrictiva que la acogida por aquél, sino, a mi juicio, también más limitada de lo que resulta de la propia Ley.

\section{III.A. La cooperación al desarrollo y los títulos competenciales}

Pero antes de detenernos sobre ese particular, será provechoso comenzar recordando que el real decreto aprobatorio del repetido Reglamento del Registro de ONGDs, cuya disposición final segunda, rubricada "título competencial», sintomáticamente, se apresura en subrayar no el hecho de que se aprueba en mérito de lo establecido en el art. 33 y la disposición final primera de la Ley 23/1998, donde se contiene el mandato y la habilitación para el desarrollo reglamentario, sino, directamente, al amparo de «lo dispuesto en el artículo 149.1.3 ${ }^{\mathrm{a}}$ de la Constitución, por el cual —explica- le corresponde al Estado la competencia exclusiva sobre "relaciones internacionales"» (título competencial que, como enseguida veremos, no impide - aunque condicione- la acción exterior de las CCAA), señalará en el antepenúltimo párrafo de su Exposición de Motivos que «algunas comunidades autónomas, haciendo uso de la facultad prevista en el artículo 33.1 de la Ley 23/1998, de 7 de julio, han creado registros de ONGDs en sus respectivos territorios».

Pues bien, tal vez, ello pudo ser interpretado así en el año 1998 -y aun entonces cabría matizar dicha afirmación-, pero, a mi juicio, en la fecha de aprobación del nuevo Reglamento, lo que, en verdad, "facultaba» a las CCAA para la creación de registros de ONGDs, más que la citada Ley estatal, serían sus respectivos Estatutos de Autonomía y la propia praxis autonómica avalada por la jurisprudencia del Tribunal Constitucional. En el mismo sentido, conviene apostillar también que tanto el Registro de ONGDs de la AECID como los que con idéntica finalidad puedan crearse en las CCAA, en rigor, no son registros de «seguridad jurídica», sino registros «administrativos», por lo que, también desde ese punto de vista, cabe considerar

25 A pesar de que en el artículo 1 del referido Reglamento de 2015 se afirma que éste [sólo] tiene por objeto regular el Registro de ONGDs dependiente de la AECID, el procedimiento de inscripción en el mismo y las relaciones de colaboración con los registros de ONGDs de las Comunidades Autónomas, es lo cierto que, tal cual acaba de exponerse en el texto, su pretensión era más amplia y pasaba por «interpretar correctivamente» la definición legal de ONGD, adicionando nuevos requisitos, como se desprende de su articulado y se confiesa sin rebozo en su Exposición de Motivos: vid., párrafos $4^{\circ}$ y antepenúltimo de la citada Exposición. 
que escapan igualmente de la competencia exclusiva del Estado a que se refiere el art. 149.1.8 CE (ordenación de los registros).

En efecto, la primera observación que convendrá formular a este respecto es que, a diferencia de otras materias, nuestra Constitución no contempla la cooperación al desarrollo más que en su Preámbulo, cuando proclama la voluntad de la Nación española de «colaborar en el fortalecimiento de unas relaciones pacíficas y de eficaz cooperación entre todos los pueblos de la Tierra». No se menciona, pues, entre las competencias exclusivas del Estado y, antes al contrario, tras el proceso de reformas estatutarias llevadas a cabo a partir de 2006, dicha materia se recogerá expresamente en diversos Estatutos como competencia de las respectivas Comunidades Autónomas, conforme autoriza el art. 149.3 CE. Es bien cierto, no obstante, que el art. 149.1.3 $3^{\mathrm{a}} \mathrm{CE}$, expresamente invocado como título habilitante por el real decreto aprobatorio del Reglamento del Registro de la AECID, se refiere a las "relaciones internacionales» como competencia exclusiva del Estado, pero, aunque es verdad que en un inicio se interpretó dicho título en clave expansiva (vid., por ejemplo, la STC 44/1982, de 8 de julio, en especial, FJ 4º o la STC 154/1985, de 12 de noviembre, $\mathrm{FJ} 5^{\circ}$ ), no lo es menos que dicha línea jurisprudencial ha ido evolucionando ${ }^{26}$ y en la actualidad - especialmente a partir de la STC 165/1994, de 26 mayo- el concepto de relaciones internacionales «ni se identifica en modo alguno con el contenido más amplio que posee dicha expresión en sentido sociológico» ${ }^{27}$ ni cabe ser interpretado en el sentido de situar dentro de su órbita cualquier tipo de actividad con alcance o proyección exterior ${ }^{28}$. Así, la mera circunstancia de que se encuentren involucrados otros países o ciudadanos extranjeros no implica necesariamente que la competencia quede residenciada en el ámbito de las relaciones internacionales ${ }^{29}$. Para el TC, «la dimensión externa de un asunto no puede servir para realizar una interpretación expansiva del art. 149.1.3 CE, que venga a subsumir en la competencia estatal toda medida dotada de una

26 Sin ánimo exhaustivo, tal evolución se constata, entre otras, a través de las siguientes sentencias: STC 44/1982, de 8 de julio (FJ. 4, pfo. último); STC 154/1985, de 12 de noviembre (FJ. 5); STC 137/1989, de 20 de julio (FFJJ. 3 y 5); STC 153/1989, de 5 de octubre de 1989 (FJ. 8); STC 17/1991, de 31 de enero (FJ. 6); STC 80/1993, de 8 de marzo (FJ. 3, pfo. $3^{\circ}$ ); STC 165/1994, de 26 mayo (FFJJ. 3 a 6); STC 206/2001, de 22 octubre; STC 31/2010, de 28 de junio (FFJJ. 73 y 125); STC 118/2011, de 5 de julio (FJ. 10); STC 138/2011, de 14 de septiembre (FJ. 4); STC 80/2012, de 18 de abril (FJ. 4); 46/2015, de 5 de marzo (FJ. 4); STC 85/2016, de 28 abril (FJ. 3); STC 228/2016, de 22 diciembre.

27 STC 165/1994, FJ. 5, pfo. $3^{\circ}$.

28 Ibidem, FJ. 5, pfo. $2^{\circ}$.

29 Ibid., FJ. 8. 
cierta incidencia exterior, por remota que sea, ya que si así fuera se produciría una reordenación del propio orden constitucional de distribución de competencias entre el Estado y las Comunidades Autónomas» ${ }^{30}$. De esta forma, aun reconociendo al Estado la posibilidad de establecer medidas que regulen y coordinen las actividades con proyección externa de las CCAA para evitar o remediar eventuales perjuicios sobre la dirección y puesta en ejecución de la política exterior que, en exclusiva, corresponde a las autoridades estatales, el invocado concepto de "relaciones internacionales» ha quedado contraído, en síntesis, a las relaciones entre sujetos internacionales regidas por el Derecho internacional, entre las que se encontraría la celebración de tratados (ius contrahendi), la representación exterior del Estado (ius legationis), la creación de obligaciones internacionales o la responsabilidad internacional del Estado ${ }^{31}$.

Evidentemente, ello no excluye la competencia estatal sobre la cooperación para el desarrollo, la cual constituye, a tenor de los arts. 14 y 24 de la ya citada Ley 2/2014, uno de los ámbitos de la Acción Exterior del Estado, pero es igualmente inconcuso que la misma no puede suponer un desapoderamiento de las CCAA. En este sentido, al margen de las competencias que, bajo distintas fórmulas, habían asumido desde un inicio respecto de las fundaciones y asociaciones que desarrollasen principalmente sus funciones en el ámbito de una Comunidad (a lo que, a mi juicio, no obstaba la referencia original de algunos Estatutos limitándolas a las de carácter docente, cultural, artístico, beneficio-asistencial y similares, toda vez que, por un lado, la enumeración no era exhaustiva - como se desprende de la expresión «y similares» que habitualmente incluían- $\mathrm{y}$, por otro, porque cabría interpretar que muchas de las actividades relacionadas con la cooperación internacional para el desarrollo podrían tener cabida dentro de las mencionadas), lo cierto es que, de hecho, aun sin una específica mención estatutaria, han venido desplegando su actividad en este ámbito ${ }^{32}$ y, en todo caso, la propia Ley 23/1998 reconocería y daría carta de naturaleza a las iniciativas de cooperación desde las

30 STC 80/1993, FJ. 3, pfo. $3^{\circ}$.

31 Por todas, STC 165/1994, FFJJ. 5 y 6; y STC 31/2010, FJ 125.

32 En este sentido, a título meramente ejemplificativo, resulta oportuno mencionar que ya antes de la Ley 23/1998 y aun sin tener atribuida estatutariamente de forma expresa competencias sobre la materia, el primer registro de ONGDs, tanto a nivel estatal como autonómico, fue el creado por la Comunidad Autónoma de Galicia: el Registro Gallego de ONGDs, establecido por la Orden de la Consejería de Presidencia y Administración Pública de 4 de abril de 1994 (DOG n 65, de 6 de abril), como se enfatiza en la Exposición de Motivos de la Ley 3/2003, de 19 de junio, de cooperación para el desarrollo de dicha Comunidad Autónoma (DOG núm. 128, de 3 de julio, BOE núm. 172, de 19 de julio). 
CCAA y las EELL (lo que se ha venido a entender como "cooperación oficial descentralizada» ${ }^{33}$ ), y con mayor motivo ha de contemplarse así tras la citada jurisprudencia constitucional y las reformas estatutarias a que se ha hecho alusión.

De ahí que, a pesar de que los desarrollos autonómicos no se hayan apartado sustancialmente del concepto de ONGD ofrecido por la Ley 23/1998, resulte dudoso que las CCAA que hayan asumido competencias en dicha materia por mor de sus Estatutos, e incluso las que sin una expresa mención estatutaria a la cooperación internacional para el desarrollo hayan desenvuelto su actividad en este ámbito creando también sus propios registros de ONGDs, se vean constreñidas, en punto a los requisitos exigibles para el acceso a los mismos, por lo que pueda interpretar una norma subalterna con un confesado propósito correctivo de cuestionable ajustamiento a la Ley que le sirve de cobertura, además de dictada (teóricamente) con un objeto distinto: el de regular un registro administrativo y no el de desarrollar el concepto de ONGD con pretensiones de eficacia en otras parcelas, como la tributaria.

\section{III.B. El RONGDs como autoproclamado custodio de la aplicación de los incentivos fiscales a la iniciativa privada en el ámbito de la cooperación al desarrollo}

En efecto, la pretensión del Reglamento de 2015 de entronizar un concepto de ONGD más restrictivo que el que figura en la Ley 23/1998; los requisitos exigidos en relación a su inscripción y al mantenimiento actualizado de su contenido; y la justificación de su dictado en mérito de la supuesta necesidad de erigir dicho Registro en una suerte de custodio de la aplicación de los incentivos fiscales de que se hacía eco el artículo 35 de la citada Ley constituyen, bajo mi punto de vista, elementos de una estrategia dirigida a afianzar la competencia estatal emulando la fórmula empleada en el caso de las asociaciones de utilidad pública ${ }^{34}$, respecto de las que se negaría la competencia autonómica para efectuar dicha declaración en cuanto ésta afecta esencialmente a los tributos estatales (dejando a salvo, claro está, la competencia de las CCAA para efectuar dicha de-

33 Vid. el art. 20 de la Ley 23/1998.

34 Aunque no puede dejar de anotarse que en ese caso se hacía por una Ley: la Ley Orgánica 1/2002, de 22 de marzo, reguladora del derecho de asociación (LODA), artículo 32 y ss. 
claración circunscrita a sus tributos ${ }^{35}$ ) frente al argumento, repetidamente rechazado por el TC, de que el centro de gravedad había de ubicarse en los fines de interés general al que sirven dichas asociaciones, por cuanto que tal declaración no es sino una medida de fomento, simplemente reconocedora de su relevancia pública; lo que, de haberse aceptado, habría atraído dicha declaración al ámbito autonómico, dada la generalizada inclusión en sus Estatutos, con mayor o menor amplitud, de competencias sobre asociaciones o, cuando menos, sobre aquellas cuyos fines y actividades coincidieran con materias de competencia autonómica ${ }^{36}$.

35 Art. 36 LODA. Véase asimismo su correspondiente en el ámbito de la Ley 23/1998: el art. 35.6, así como las SSTC 176/1999, de 30 de septiembre (FJ 4), y 74/2000, de 16 de marzo (FJ 3), relativas a la intangibilidad de los tributos estatales por determinadas medidas autonómicas.

36 En este sentido, en el recurso interpuesto por el Parlamento de Cataluña contra diversos preceptos de la LODA —resuelto por la STC 133/2006, de 27 de abril—, el Letrado de dicha Comunidad alegaría que la invocación del título competencial del art. 149.1.14 CE (Hacienda General) para establecer un régimen uniforme en la regulación de las asociaciones de utilidad pública resultaba abusiva "puesto que con esta figura — en referencia a la aludida declaración — se pretende fomentar el asociacionismo y la participación de las asociaciones en la promoción de actividades de interés general, no resolver cuestiones atinentes al funcionamiento de la hacienda pública y a los ingresos y gastos del Estado", por lo que defendería la "prevalencia del título específico "asociaciones" del art. 9.24 EAC[de 1979] sobre el genérico "Hacienda general" del art. 149.1.14 CE, habida cuenta, además, de que la declaración de una asociación como de utilidad pública no tiene efectos únicamente fiscales, según se aprecia en el art. 33 LODA». El argumento, como se señala en el texto, sería rechazado por el TC sobre la base de conectar la competencia para declarar determinadas asociaciones "de utilidad pública" con la principal consecuencia legal atribuida a dicha declaración, a saber, la de disfrutar de un régimen fiscal especial, entonces ya compendiado en la Ley 49/2002 (vid. los FFJJ 17 y 18 de la citada sentencia). Y ello no solamente en aquel asunto. También reiteraría ese criterio en la polémica STC núm. 31/2010, de 28 de junio (vid. Antecedente 59 y FJ. 66), relativa al no menos controvertido Estatuto catalán de 2006, en cuyo art. 118.1.b) se atribuye a dicha Comunidad la competencia para «la determinación y el régimen de aplicación de los beneficios fiscales de las asociaciones establecidos en la normativa tributaria -así, sin precisión alguna-, así como la declaración de utilidad pública, el contenido y los requisitos para su obtención", disponiéndose otro tanto en el art. 118.2.b) en relación a las fundaciones; preceptos ambos que el TC mantuvo, pero entendiendo circunscrita la competencia autonómica a los beneficios fiscales sobre tributos no estatales, con expresa remisión a la citada STC 133/2006. Lo mismo sucedería en la STC núm. 134/2006 (Pleno), de 27 abril, en el recurso promovido por dicha Comunidad contra diversos artículos del RD 1740/2003, de 19 de diciembre, sobre procedimientos relativos a asociaciones de utilidad pública, cuyo FJ $6^{\circ}$ resulta bien elocuente: "... la competencia de la Administración General del Estado para declarar asociaciones de utilidad pública se justifica porque dicha declaración convierte a las entidades beneficiarias en sujetos que gozan de un régimen especial en la normativa fiscal y económica dictada por el Estado». 
No obstante, en mi sentir, la reforma reglamentaria no tendría que haber prosperado en los términos en que quedaría aprobada, no ya por su eventual incidencia en las competencias autonómicas y la desigualdad que puede engendrar entre dichas organizaciones según dónde se inscriban, sino, sobre todo, por los escasos mimbres que presta la propia Ley 23/1998, que parece inclinarse por una noción de ONGD más abierta (sin perjuicio de que, a efectos del disfrute de determinadas ayudas o beneficios, pueda luego restringir las mismas a aquellas ONGDs que reúnan ciertas condiciones) ${ }^{37}$.

En efecto, resulta relevante señalar que la exposición de motivos del Real Decreto aprobatorio del repetido Reglamento del Registro de ONGDs de 2015 justificaba su tenor aduciendo que «[e]l acceso al Registro constituye, tal como establece el citado artículo 33 de la Ley 23/1998, de 7 de julio, una condición indispensable para recibir de las Administraciones públicas ayudas y subvenciones computa-

Adviértase que en el caso que nos ocupa, según la filosofía que, a tenor de su exposición de motivos, parece inspirar dicho Reglamento, la inscripción en el registro de ONGDs cumpliría análoga función. Dicho en otros términos, la enfatizada vinculación entre los beneficios del régimen fiscal especial de las ESFL y la inscripción en el Registro de la AECID (obviando, como veremos, la mención de los registros autonómicos) no parece inocente ni casual.

37 Aunque el dictamen del Consejo de Estado sobre el proyecto de Reglamento del Registro de ONGDs actualmente vigente terminaría resultando a la postre demasiado indulgente (al punto de que, en mi opinión, no quedaron adecuadamente depurados todos los excesos en que había incurrido dicho proyecto), la advertencia preliminar realizada por el Alto órgano consultivo resultaba bien elocuente y en línea con lo que, por mi parte, señalaba antes en el texto:

"Con carácter general - decía el dictamen-y al margen de otras observaciones de menor calado que se realizarán en un momento ulterior, $\boldsymbol{e l}$ Consejo de Estado debe advertir sobre la extralimitación en la que incurre el texto del Reglamento sometido a consulta, que exige para la inscripción de las Organizaciones no Gubernamentales de Desarrollo numerosos requisitos adicionales a los previstos en la Ley 23/1998 en cuyo cumplimiento y ejecución se dicta. La razón de esta extralimitación puede responder a la idea, presente en el propio preámbulo de la norma y en varios de los informes que obran en antecedentes, de que, en tanto que la inscripción habilita para recibir ayudas y acceder a incentivos fiscales, es preciso verificar la idoneidad de las entidades y la veracidad de los datos inscritos». Concluyendo más adelante: "no corresponde a un texto como el sometido a consulta... establecer requisitos adicionales a los legalmente previstos que interfieren en la finalidad de publicidad perseguida. [...] Lo contrario no solo frustraría la finalidad perseguida por la Ley 23/1998 [...], sino que supondría una desigualdad en el acceso a las ayudas públicas y a un régimen fiscal especial frente a ONGD inscritas en Registros autonómicos -expresamente previstos en el artículo 33.1 de la Ley 23/1998- que no exijan los requisitos que el artículo 4 del proyecto de Reglamento impone». [Cfr., Dictamen del Consejo de Estado de 17 de diciembre de 2014, núm. de expediente 1160/2014 (Asuntos Exteriores y de Cooperación), apdo. IV, pfo. cuarto y último, págs. 10-15. La cursiva e iluminados son míos]. 
bles como ayuda oficial al desarrollo, a la vez que permite acceder a los incentivos fiscales que prevé el artículo 35. Esta circunstancia continuaba diciendo su exposición de motivos-obliga a verificar la idoneidad de las entidades que se inscriben, así como la veracidad de los datos inscritos, y a tomar las medidas necesarias para que la información recogida se mantenga actualizada, consiguiendo el más alto nivel de fidelidad del Registro a la realidad ${ }^{38}$.

Resulta difícil compartir plenamente dicha justificación. Adviértase que una cosa es que las ONGDs hayan de estar inscritas en dicho Registro para poder disfrutar de determinadas ayudas y beneficios fiscales (lo que, en el momento de dictarse el Reglamento de 2015, incluso podía resultar ya cuestionable respecto de estos últimos, a pesar de lo expresamente sostenido en el mismo ${ }^{39}$, habida cuenta de que entonces regía, y rige, una Ley — la Ley 49/2002_ distinta de la que se encontraba vigente cuando se aprueba la Ley 23/1998 — a saber, la derogada Ley 30/1994, que es a la que ésta remitía- $)^{40}$ y otra cosa bien diferente que las ONGDs puedan acceder directamente al disfrute de tales ayudas y beneficios fiscales por

38 Exposición de Motivos, pfo. segundo, del RD 193/2015, de 23 de marzo. Véase, asimismo, el art. 10 del referido Reglamento.

39 Nótese que el artículo 10 del referido Reglamento, con la excusa de regular los «efectos de la inscripción» en el Registro de la AECID [así luce engañosamente en su título, cuando, en rigor, lo que contempla son más bien los efectos de «la falta de inscripción» o, más exactamente: cuando lo que pretende es (r)establecer la obligatoriedad de estar registradas en el mismo como requisito para disfrutar de los beneficios fiscales de las entidades sin fin de lucro], viene a reproducir en su texto - y no fielmente, porque omite los registros autonómicos- un mandato supuestamente amparado en el art. 33.2 de la Ley 23/1998 (precepto legal que si continuaba vigente resultaba ocioso reiterar $-\mathrm{y}$, en todo caso, en buena técnica jurídica, no le correspondía dictar- y que, si ya no lo estaba, su «resurrección» vía reglamentaria resulta evidentemente ilegal), en el que dispondría:

«Artículo 10. Efectos de la inscripción. De acuerdo con el artículo 33.2 de la Ley 23/1998, de 7 de julio, la inscripción en el Registro de ONGD será condición indispensable para recibir de la Administración General del Estado, en el ámbito de sus competencias, ayudas o subvenciones computables como ayuda oficial al desarrollo, así como para el acceso a los incentivos fiscales a que se refiere el artículo 35 de la misma norma».

Inciso, este último, que pretende reproducir —a su modo- el también último inciso del citado art. 33.2, pero cuya vigencia, como se indica en el texto, resulta cuando menos cuestionable.

40 A lo que, siguiendo esta hipótesis, no obstaría, según luego explicaremos con más detalle, que la DA $17^{\text {a }}$ de la Ley 49/2002 previniese que "Las remisiones normativas realizadas al Título II de la Ley 30/1994 [...] se entenderán hechas a los preceptos de esta Ley», porque, obviamente, ello sólo cabe en aquello que no se oponga a lo establecido a la Ley 49/2002 y, tras la aprobación de ésta, cabría argüir que el último inciso del art. 33.2 y el art. 35.1 de la Ley 23/1998 no se compadecen, en punto a la exigencia de estar inscritas en el Registro de ONGDs, con lo dispuesto en la Ley 49/2002. Al respecto, véase lo que más adelante se expone en el apartado IV.A.1.

(C) UNED. Revista de Derecho UNED, núm. 27, 2021 
el hecho de estar inscritas en dicho Registro (que, en su caso, es lo que justificaría verificar ciertos requisitos en el momento de la inscripción). El Registro de ONGDs no es un registro fiscal y, por otro lado, la comprobación de la veracidad de los datos para que las ONGDs allí censadas puedan aplicar válidamente el régimen de la Ley 49/2002 es labor de los órganos de la Hacienda Pública, no del encargado del Registro de ONGDs.

\section{III.C. La (pretendida) ausencia de instrumentos de cooperación entre los Registros de ONGDs}

Tampoco resulta convincente la otra explicación aducida en la Exposición de Motivos del nuevo Reglamento: a saber, la falta de previsión en el antiguo de los oportunos instrumentos de cooperación entre el registro estatal de ONGDs y los registros autonómicos. A este respecto, si nos atuviéramos a ello, deberíamos entender que tal «laguna» habría sido colmada por su art. 15, que prevé la posibilidad de suscribir convenios de colaboración para asegurar la comunicación y homologación de los datos registrales por medios electrónicos ${ }^{41}$. Sin embargo, al margen de la alusión a tales medios, no se adivina cuál es el plus que verdaderamente aporta el nuevo precepto reglamentario: que la AECID pudiera suscribir convenios de colaboración era algo que cabía colegir tanto del art. 33 de la Ley 23/1998, a que ya antes hicimos mención ${ }^{42}$, como de la antigua LRJPAC $^{43}-\mathrm{a}$ la sazón vigente en el momento de dictarse el nuevo Reglamento del RONGDs-, en cuyo art. 6.1 se establecía que «La Administración General y los Organismos públicos vinculados o dependientes de la

41 El referido precepto dispone:

"Artículo 15. Relaciones de colaboración entre el Registro de ONGD y las comunidades autónomas. 1. La AECID podrá suscribir los convenios de colaboración que resulten necesarios con los registros de ONGD de las comunidades autónomas, así como con aquellas comunidades autónomas que no posean registro propio para la regulación del intercambio de información a fin de asegurar la comunicación y la homologación de datos registrales.

2. El Registro de ONGD facilitará a los registros de ONGD de las comunidades autónomas cuantos datos, documentos o medios probatorios se hallen a su disposición y se precisen para el ejercicio de sus propias competencias.

3. Los intercambios de documentación y de datos entre los registros se realizarán preferentemente por medios electrónicos».

42 Como vimos, el art. 33.1 de la citada Ley prevenía en su párrafo último que se establecieran los correspondientes procedimientos de colaboración entre la AECID y las CCAA, a fin de asegurar la comunicación y homologación de los datos registrales.

43 Ley 30/1992, de 26 de noviembre, de Régimen Jurídico de las Administraciones Públicas y del Procedimiento Administrativo Común (BOE núm. 285, de 27 noviembre). 
misma podrán celebrar convenios de colaboración con los órganos correspondientes de las Administraciones de las Comunidades Autónomas en el ámbito de sus respectivas competencias» ${ }^{44}$. Todo ello, sin olvidar lo preceptuado en la disposición adicional segunda del propio real decreto aprobatorio del reglamento anterior, cuya dicción no distaba mucho de la del referido artículo $15^{45}$. En este sentido, la explicación dada en la exposición de motivos de que el anterior reglamento del Registro de ONGD «no preveía la articulación de instrumentos de cooperación entre éste y los registros autonómicos, más allá del mandato genérico introducido por el legislador en el citado artículo» (en referencia al art. 33.1 de la Ley 23/1998) ${ }^{46}$, por lo que «esta circunstancia trata de ser subsanada [sic] en la nueva redacción del Reglamento ${ }^{47}$, constituye, en mi sentir, un simple pretexto cuya justificación, en verdad, ha de buscarse en otra parte. Adviértase que si bien el anterior no lo hacía ${ }^{48}$, es lo cierto que el art. 15 del nuevo RRONGDs tampoco está «articulando un procedimiento de colaboración» —que es lo que ordena el art. 33.1 de la Ley— ni establece siquiera cómo ni cuándo queda asegurada la comunicación y homologación de los datos: es, en ese sentido, un precepto perfectamente prescindible que nada está «subsanando».

44 La posterior Ley 40/2015, de 1 de octubre, de Régimen Jurídico del Sector Público (BOE» núm. 236, de 2 de octubre) ha abundado en su regulación, contemplándolos tanto en el capítulo VI de su Título Preliminar (Cap. VI: «De los convenios», arts. 47 a 53) como en su Título III: «Relaciones interadministrativas» (art. 140 y ss.).

45 Recordaré que la citada disposición adicional segunda del RD 993/1999, de 11 de junio, por el que se aprobaba el anterior Reglamento de Registro de ONGDs, establecía que: «Para asegurar el cumplimiento de la obligación de comunicación y homologación de datos entre el Registro regulado por este Real Decreto y los que con idéntica finalidad puedan crearse en las Comunidades Autónomas, la Agencia Española de Cooperación Internacional 'concertará' con las autoridades autonómicas la elaboración de los correspondientes procedimientos de colaboración».

46 Exposición de Motivos del RD 193/2015, de 23 de marzo, antepenúltimo párrafo.

47 Ibidem.

48 En su propia Exposición de Motivos confesaba que «El presente Reglamento tiene por objeto establecer las pautas para el funcionamiento práctico de dicho Registro, sin perjuicio de que, en su momento, se articulen los procedimientos correspondientes para asegurar la comunicación y homologación de datos con los Registros que, con idéntica finalidad, puedan crearse en las Comunidades Autónomas». Cfr. E. de M. del citado RD 993/1999, penúltimo párrafo. 


\section{III.D. La ruptura de la paridad entre el Registro de la AECID y los Registros autonómicos}

Por lo demás, se echa en falta una norma, como la del art. 2 del Reglamento del Registro Nacional de Asociaciones ${ }^{49}$ o como la del art. 11 del Reglamento del Registro de Fundaciones de Competencia Estatal ${ }^{50}$, que permita establecer cuándo una ONGD ha de inscribirse en el Registro de la AECID y cuándo en los Registros establecidos en las respectivas CCAA, no siendo vano señalar que, prima facie, el Reglamento de 2015 parece haber roto la paridad establecida en la Ley 23/1998 entre el Registro de la AECID y los Registros autonómicos, de manera que de su tenor cabría inferir que aquellas ONGDs no inscritas en el registro estatal no podrán recibir de la Administración General del Estado ni ayudas ni subvenciones computables como ayuda oficial al desarrollo (AOD), ni disfrutar tampoco del régimen de la Ley 49/2002 ${ }^{51}$ ), sin perjuicio de que, tanto ahora como antes (vid. los arts. 34 y 35.6 de la Ley 23/1998), las ONGDs inscritas en los Registros de las CCAA sí puedan gozar de ayudas o subvenciones autonómicas o de incentivos fiscales en sus tributos, si así se previniese por aquéllas en el ámbito de sus competencias.

A este respecto se ha de señalar que en el art. 2 del derogado Reglamento del RONGDs de 1999 se establecía que debían inscribirse en el Registro de la AECID las ONGDs «que deseen recibir de las Administraciones públicas — repárese, en plural- ayudas o subvenciones computables como ayuda oficial al desarrollo, así como disfrutar de los incentivos fiscales a que se refiere el artículo 35 de la Ley 23/1998». A lo que añadía seguidamente: "Todo ello»-a saber, tanto el disfrute de las ayudas o subvenciones como el de los beneficios fiscales enunciados en el referido art. 35- «sin perjuicio» de que aquéllas «puedan inscribirse en los registros que, con idéntica finalidad, puedan crearse en las CCAA, en los términos del artículo 33 de la misma Ley 23/1998», lo que, en sintonía con el apartado $2^{\circ}$ de dicho art. 33, así como con el art. 35.1 de la misma Ley, autorizaba a interpretar que podían disfrutar del régimen fiscal de la entonces Ley 30/1994, aunque no se hubieren inscrito en el Registro de la AE-

49 Aprobado por el RD 949/2015, de 23 de octubre (BOE núm. 255, de 24 de octubre). enero).

50 Aprobado por el RD 1611/2007, de 7 de diciembre (BOE núm. 17, de 19 de

51 Si es que se reputan vigentes el último inciso del art. 33.2. y el art. 35 de la citada Ley. Vid., infra, apdo. IV.A.1. 
CID, si lo estuvieran en el correspondiente Registro autonómico de idéntico fin ${ }^{52}$.

En cambio, en el art. 10 del actual Reglamento de 2015 se dirá, distintamente, que la inscripción en el Registro de la AECID es condición indispensable para recibir de la Administración General del Estado, en el ámbito de sus competencias, ayudas o subvenciones computables como ayuda oficial al desarrollo, así como para el acceso a los incentivos fiscales a que se refiere el artículo 35 de la Ley 23/1998. No se menciona ya a los Registros autonómicos, lo que contrasta con lo establecido en la repetida Ley (cfr. su art. 33.2), que habla de la inscripción "en alguno de dichos Registros», es decir, tanto en el de la AECID como en los que con idéntica finalidad puedan crearse en las CCAA. En el mismo sentido, su art. 35.1 prevenía que «El régimen tributario de las entidades sin fines lucrativos [...] resultará aplicable a las organizaciones no gubernamentales de desarrollo inscritas en los Registros —nótese de nuevo: en plural- siempre que revistan la forma jurídica y cumplan con los requisitos exigidos en el mismo", id est, en el capítulo I del Título II de la Ley 30/1994, que era la vigente cuando se aprueba la Ley 23/1998.

En definitiva, en una primera lectura, la dicción del nuevo Reglamento del RONGDs parece constreñir los incentivos fiscales que recoge el art. 35 de la Ley sólo a las ONGDs inscritas en el Registro de la $A E C I D$, sin perjuicio de que las que lo estén en Registros de las CCAA puedan recibir ayudas y subvenciones autonómicas o disfrutar de incentivos fiscales en los tributos de su competencia.

No obstante, por apurar las exégesis posibles, se me antoja otra interpretación; a saber, considerar que lo que sucede no es que con la supresión de las referencias a los registros autonómicos el actual Reglamento pretenda impedir que las ONGDs que se inscriban en éstos puedan disfrutar de ayudas y subvenciones estatales y, en su caso, optar por los beneficios fiscales establecidos en la Ley 49/2002, sino que aquél se habría limitado a regular lo relativo al Registro dependiente de la AECID omitiendo cualquier mandato respecto de los au-

52 Así se desprendía también de la propia tramitación parlamentaria de la Ley 23/1998. En este sentido se debe recordar que la redacción final de los arts. 33 y 35 en los indicados aspectos fue debida a las enmiendas presentadas por los Grupos Parlamentarios Vasco y Catalán (CiU), dirigidas a establecer esa equiparación entre el Registro de la AECID y los autonómicos, las cuales fueron aceptadas en la Ponencia sobre el Proyecto de Ley. Vid., las enmiendas núms. 69 y 70 del Grupo Parlamentario Vasco: BOCG, VI Legislatura, serie A, núm. 81-7, de 17 de noviembre de 1997, pág. 73, y las enmiendas núms. 343, 345 y 347 del Grupo Parlamentario Catalán (CiU): Ibidem, pág. 142-143. Vid., asimismo, el Informe de la Ponencia en BOCG, VI Legislatura, serie A, núm. 81-10, de 30 de marzo de 1998, pág. 175-176.

(C) UNED. Revista de Derecho UNED, núm. 27, 2021 
tonómicos, por cuanto no correspondería al Estado dicha competencia, y sin que, por consiguiente, dicho Reglamento prejuzgue, en absoluto, la posibilidad de que las ONGDs inscritas en esos otros registros autonómicos puedan gozar también del régimen fiscal de las ESFL. Evidentemente, la consecuencia de esta otra interpretación sería que las CCAA podrían regular la inscripción en los registros que creasen exigiendo requisitos distintos (v.gr., congruentes con la definición de la Ley 23/1998, pero menos rigurosos que los que ahora impone el Reglamento del Registro de la AECID), de forma que, a la postre, el acceso al régimen fiscal de la Ley 49/2002 pudiera ser diferente para unas entidades que para otras, dependiendo de dónde se hayan inscrito ${ }^{53}$. No me parece, sin embargo, que esa fuera, desde luego, la intención del nuevo Reglamento, sino antes al contrario.

Ahora bien, en todo caso, tal consecuencia sólo se daría - permítaseme insistir - en el supuesto de que se considere vigente el último inciso del art. 33.2 y el art. 35.1 de la Ley 23/1998, pues, si dichos preceptos se estiman superados por la Ley 49/2002, los requisitos - más allá de los que resultan de la definición de ONGD del artículo 32.1 de la Ley 23/1998, expresamente aceptada por el art. 2.c) de la Ley 49/2002-, serían ya los que establece el art. 3 de la repetida norma fiscal ${ }^{54}$, de manera que no se daría, pues, desigualdad en la aplicación del régimen tributario especial, y la diversidad que pudiera resultar de los requisitos eventualmente impuestos para su inscripción en los diferentes registros autonómicos sólo afectaría a las ayudas y subvenciones.

\section{III.E. La finalidad esencial del RONGDs: la publicidad formal}

En definitiva, a mi juicio, el Registro de ONGDs debía dar cabida de modo amplio a cualesquiera entidades privadas y sin ánimo de lucro que, según sus estatutos, tuvieran como fin la realización de actividades relacionadas con la cooperación al desarrollo, porque, sin perjuicio de constituir un instrumento para la gestión de la ayuda al desarrollo proveniente de la Administración General del Estado, la otra función esencial de dicho registro administrativo es la de publicidad formal, con independencia de que, luego, alguna de las entidades inscritas en el mismo disfruten de los beneficios del régi-

53 Lo que resulta claramente problemático, sobre todo, si se admite la tesis de que las ONGDs con "forma» de asociación pueden acceder a dicho régimen fiscal, aunque no estén declaradas de utilidad pública, si se encuentran inscritas en cualquier registro autonómico dedicado ese fin.

54 Vid., infra, págs. 340 y ss. 
men de la Ley 49/2002 y otras no, porque no puedan o simplemente porque no quieran sujetarse a alguno de los requisitos que éste impone (v.gr., porque consideren que así preservan su independencia frente a los poderes públicos), pero sin que por ello dejen de merecer la consideración de ONGDs de acuerdo con la definición legal de la Ley 23/1998.

Por consiguiente, las trabas que puedan oponerse a su inscripción, en cuanto, por un lado, impiden esa publicidad que las permite hacerse más visibles facilitando que puedan obtener el respaldo social de mecenas y voluntarios (fundamental para su supervivencia como organizaciones), y, por otro, condicionan el eventual disfrute de subvenciones y ayudas computables como AOD, así como de los beneficios fiscales que glosa en su art. 35 (caso de que se considere en vigor tanto ese artículo como el último inciso del art. 33.2), constituyen obstáculos que han de ser interpretados de forma restrictiva, dada la implicación del derecho de asociación y, más ampliamente, la participación de todos los ciudadanos, y de los grupos en que se integran, en la vida política, económica, cultural y social (art. $9.2 \mathrm{CE})^{55}$. Así pues, sólo resultan aceptables en tanto en cuanto su no exigencia supusiese inscribir y, por tanto, considerar como ONGDs a entidades que carecen de las cualidades que les permitieran ser reconocidas como tales.

55 Aun cuando por razones de extensión no podemos detenernos aquí en ello y, sin duda, sería necesario introducir importantes matices, resulta oportuno, no obstante, traer a colación el Informe del Relator Especial sobre los derechos a la libertad de reunión pacífica y de asociación, MAINA KIAI, presentado al Consejo de Derechos Humanos de Naciones Unidas en su $20^{\circ}$ período de sesiones, en cuyo parágrafo 68 manifestaba: «Todas las asociaciones, estén o no registradas, deben disfrutar del derecho a recabar y obtener financiación de entidades nacionales, extranjeras e internacionales, incluidos particulares, empresas, organizaciones de la sociedad civil, gobiernos y organizaciones internacionales. Sin embargo, el Relator Especial señala con preocupación que en algunos países únicamente las asociaciones registradas reúnen las condiciones para recibir financiación y recursos. En este contexto, parece esencial que en las normas que regulan la creación de asociaciones se tengan en cuenta las mejores prácticas mencionadas, a fin de permitir el acceso de toda asociación a financiación y recursos.» Cfr., ONU: CONSEJO DE DeRechos Humanos, Informe del Relator Especial sobre los derechos a la libertad de reunión pacífica y de asociación, Maina Kiai, 21 mayo 2012, A/HRC/20/27, párr. 68, disponible en:

<https://www.ohchr.org/Documents/HRBodies/HRCouncil/RegularSession/ Session20/A-HRC-20-27_sp.pdf> [Fecha último acceso:16/02/2020].

(C) UNED. Revista de Derecho UNED, núm. 27, 2021 


\section{III.F. Los vínculos de dependencia: el carácter de no gubernamental}

En este sentido, se me antoja más que cuestionable, por ejemplo, que, a efectos de su inscripción en dicho Registro, no pueda considerarse ONGD a una entidad dedicada a la realización de actividades relacionadas con la cooperación al desarrollo por el hecho de que en sus órganos de gobierno se encuentren representadas administraciones públicas o entidades del sector público con un porcentaje de participación superior al 30 por ciento ${ }^{56}$.

Piénsese, en relación a dicho porcentaje, que, por ejemplo, en el caso de las fundaciones, la actual Ley 40/2015, de 1 de octubre, de Régimen Jurídico del Sector Público (LRJSP) establece criterios distintos para considerar a una fundación como integrante del sector público. Así, en su art. 128.1, la citada LRJSP dispone:

«1. Son fundaciones del sector público estatal aquellas que reúnan alguno de los requisitos siguientes:

a) Que se constituyan de forma inicial, con una aportación mayoritaria, directa o indirecta, de la Administración General del Estado o cualquiera de los sujetos integrantes del sector público institucional estatal, o bien reciban dicha aportación con posterioridad a su constitución.

b) Que el patrimonio de la fundación esté integrado en más de un 50 por ciento por bienes o derechos aportados o cedidos por sujetos integrantes del sector público institucional estatal con carácter permanente.

c) La mayoría de derechos de voto en su patronato corresponda a representantes del sector público institucional estatal».

56 Recordemos que el citado artículo 4.2 del Reglamento del RONGDs dispone literalmente:

«Artículo 4. Ámbito subjetivo. [...] 2. Las Organizaciones No Gubernamentales de Desarrollo inscritas en el Registro de ONGD no podrán mantener una relación jurídica de dependencia con ninguna administración pública o entidades del sector público. Se presumirá esta relación de dependencia cuando en [sic] sus órganos de gobierno estén formados en más de un 30 por 100 por personas que actúen en representación de administraciones públicas o entidades del sector público.

En ningún caso serán reconocidas como Organizaciones No Gubernamentales de Desarrollo, a los efectos del presente Reglamento, las universidades, los partidos políticos, los colegios profesionales, las cámaras oficiales de comercio, industria y navegación, las organizaciones empresariales y los sindicatos». 
Tampoco el criterio del Reglamento coincidía con los del art. 44 de la Ley 50/2002, de 26 de diciembre, de fundaciones — a la sazón aún vigente en el momento de dictarse aquél-, en el que se disponía:

«A los efectos de esta Ley, se consideran fundaciones del sector público estatal aquellas fundaciones en las que concurra alguna de las siguientes circunstancias:

a) Que se constituyan con una aportación mayoritaria, directa o indirecta, de la Administración General del Estado, sus organismos públicos o demás entidades del sector público estatal.

b) Que su patrimonio fundacional, con un carácter de permanencia, esté formado en más de un 50 por 100 por bienes o derechos aportados o cedidos por las referidas entidades».

Como puede colegirse de lo expuesto, entre las fundaciones "privadas» y las del «sector público», el Reglamento que comentamos, con la excusa, según afirma, de "desarrollar la somera definición de ONGD que proporciona el artículo 32 de la Ley 23/1998», que, según manifiesta, adolecería de una "fuerte indeterminación», entre otros aspectos, en lo concerniente al «carácter no gubernamental» de las organizaciones que han de acceder a dicho registro ${ }^{57}$, introduce una noción, la de entidad «dependiente» que excluye de la consideración de organización «no gubernamental» a aquellas que - prescindiendo de su naturaleza, institucional o asociativa - mantengan vínculos «jurídicos» de dependencia con las administraciones y entidades del sector público. Criterio que, en mi opinión, en los términos en que se encuentra formulado en el Reglamento, carece de suficiente respaldo en la Ley - que se refiere sólo a que se trate de "entidades de Derecho privado»- y cuya concreción, en todo caso, tampoco aparece argumentada: ¿por qué cifrar los vínculos de dependencia atendiendo al porcentaje de participación en los órganos de gobierno - porcentaje que, además, no se justifica (¿por qué el 30 por ciento? $)^{58}$ - y se desdeñan otros criterios y otros vínculos, como los tipo económico o de cualquier otro género, aunque no se materialicen bajo la fórmula de un porcentaje de participación en sus órganos de dirección, pero que, sin embargo, pongan de relieve la existencia de un control o subordinación al poder político?

57 Cfr., párrafo $4^{\circ}$ de la Exposición de Motivos del RD 193/2015, aprobatorio del reiterado Reglamento del Registro de ONGDs.

58 Igual reproche sería efectuado, asimismo, por el Consejo de Estado en su referido Dictamen de 17 de diciembre de 2014 (cfr. apdo. V, pág. 15, en relación al art. 4.2 del Proyecto), aunque sin censurar el porcentaje. 
Adviértase, por otra parte, cómo - tal vez sin pretenderlo- ello supone, además, excluir de las ayudas, subvenciones y beneficios a aquellas entidades sin fin de lucro, fruto de la colaboración públicoprivada, que institucionalicen iniciativas de diversos orígenes, pero en las que, aun existiendo en su seno un dominio mayoritario de entidades privadas que asegure su independencia, las administraciones y entidades públicas puedan ostentar, en total, un porcentaje superior a ese 30 por ciento.

A este respecto, cabría recordar que el art. 2.6 de la LO 1/2002, de 22 de marzo, de Asociaciones (LODA), establece que "Las entidades públicas podrán ejercitar el derecho de asociación entre sí, o con particulares, como medida de fomento y apoyo, siempre que lo hagan en igualdad de condiciones con éstos, al objeto de evitar una posición de dominio en el funcionamiento de la asociación», pero sin referirse a porcentaje alguno. Habiéndose de traer a colación igualmente el art. 84.2, párrafo primero, de la LRJSP que dispone que «La Administración General del Estado o entidad integrante del sector público institucional estatal no podrá, por sí misma ni en colaboración con otras entidades públicas o privadas, crear, ni ejercer el control efectivo, directa ni indirectamente, sobre ningún otro tipo de entidad distinta de las enumeradas en este artículo [v.gr., sobre una asociación, que no se encuentra entre las que enumera], con independencia de su naturaleza y régimen jurídico».

En otras palabras, nuestro Ordenamiento proscribe que las entidades públicas puedan crear o participar en entidades privadas del «tercer sector» - ya se dediquen a la cooperación al desarrollo, a la acción social o a otros fines de interés general- ejerciendo sobre las mismas un control directo o indirecto que desvirtúe su naturaleza, pero sin cifrar ese dominio en un porcentaje como el que establece el RRONGDs en su art. 4, haciendo, a lo más, referencia a la «mayoría» de derechos de voto, lo que, desde luego, no coincide con lo señalado en el repetido Reglamento.

\section{III.G. Los vestigios de la exigencia de haber desarrollado sus actividades con anterioridad}

Igual juicio negativo merecía, en fin, la exigencia de haber desarrollado sus actividades con anterioridad a la solicitud de inscripción en el RONGDs (recordaré que, aunque no pasaría al texto definitivamente aprobado, el proyecto de reglamento demandaba, entre otros requisitos, un período previo de dos años y que durante ese 
mismo plazo estuvieren financiadas con fondos propios), en la medida en que ello condiciona el acceso a este Registro, cuya finalidad principal, como ya señalé, es la de constituir un instrumento para la publicidad de las ONGDs ${ }^{59}$

A este respecto, aunque, como se ha dicho, tales exigencias se enmendaron en la redacción final del Reglamento, debe anotarse que sus huellas han quedado marcadas en su texto, generando alguna incertidumbre interpretativa.

59 Así lo destacaría también el Consejo de Estado en su referido Dictamen sobre el proyecto de Reglamento del RONGDs: «El Reglamento proyectado — diría el Alto órgano consultivo- exige (en concreto en los artículos 4 y 7), a efectos de acreditar que la entidad dispone de estructura susceptible de garantizar suficientemente el cumplimiento de sus objetivos, la reunión de diversos requisitos tales como la inscripción en el Registro correspondiente a su naturaleza jurídica al menos dos años antes de la solicitud de inscripción en el Registro de Organizaciones no Gubernamentales de Desarrollo, acreditar la realización de al menos dos proyectos, programas o actividades relacionadas con los principios y objetivos de la cooperación internacional para el desarrollo, la acción humanitaria o la educación para el desarrollo en los últimos dos años y la acreditación de una financiación continuada procedente de fondos propios durante los últimos dos años», concluyendo a tal respecto que «... las características y condiciones que deban cumplir las Organizaciones no Gubernamentales de Desarrollo para poder acceder a las ayudas y subvenciones públicas deben delimitarse y definirse en las normas correspondientes [con expresa referencia a las que regulan las subvenciones y ayudas en el ámbito de la cooperación internacional], pero no en aquella que disciplina el acceso a un Registro cuya función lo es de publicidad». "En definitiva - sentaría el Dictamen- no corresponde a un texto como el sometido a consulta, cuyo contenido debe limitarse a regular el funcionamiento del Registro (estructura, asientos, títulos inscribibles, publicidad formal) y los aspectos relativos a la inscripción de las entidades que reúnen los elementos exigidos por los artículos 32 y 33 de la Ley 23/1998, establecer requisitos adicionales a los legalmente previstos que interfieren en la finalidad de publicidad perseguida». Y añadía: «La finalidad señalada por el Consejo de Cooperación al Desarrollo de que las ONGD no se nutran solo de ayudas públicas no se alcanza de forma necesaria mediante el establecimiento de condiciones para la inscripción en el Registro, sino que puede lograrse de forma más adecuada a las previsiones de la Ley 23/1998 mediante la sujeción a tales requisitos para el acceso a las ayudas y subvenciones públicas en la definición que de ellos corresponda determinar en cada convocatoria». Cfr., Dictamen del Consejo de Estado de 17 de diciembre de 2014, cit., apdo. IV, págs. 13 y 14.

Análoga crítica se contenía en el voto particular formulado por las organizaciones sindicales CCOO y UGT en el Informe del Consejo de Cooperación al Desarrollo sobre el Proyecto de Real Decreto por el que se aprueba el Reglamento del Registro de ONGDs, de fecha 12 de mayo de 2014: «La introducción en el reglamento de nuevos requisitos como el plazo previo de inscripción previa a la solicitud (punto 4 a), la realización previa de proyectos (punto 4 b) y la financiación continuada procedente de fondos propios en años anteriores al registro (punto 4 c), supera ampliamente la clarificación del concepto de ONGD». El referido informe y el voto particular a que hemos hecho mención puede consultarse en el sitio:

$<$ http://www.consejocooperacion.es/wp-content/uploads/2015/12/Informe-

Consejo-Reglamento-ONGD.pdf>. Fecha acceso doc.: 23/09/2018. 
Así sucede, por ejemplo, en el artículo 7, cuando, en relación a la «documentación que debe aportarse con la solicitud de primera inscripción» -nótese: «primera»- exige que se acompañe: «e) Declaración responsable del representante legal de la entidad en la que se incluya una breve descripción de la actividad que realiza la entidad, el sector al que se dirige su actuación, la relación de actividades, proyectos y programas que la entidad haya realizado en materia de cooperación internacional para el desarrollo, así como, en su caso, las subvenciones y ayudas destinadas a la cooperación internacional para el desarrollo recibidas por parte de las administraciones públicas o por donantes internacionales». Obsérvese: "actividad que realiza», "actividades, proyectos y programas que haya realizado", "subvenciones y ayudas recibidas»... Tiempo presente y pasado. Ni un solo "en su caso» o que "se proponga realizar». No es de extrañar, si dichos tiempos verbales se ponen en relación con la exigencia del art. 4.3 de que "desarrolle su actividad de manera continuada», que pueda suscitarse la duda de si es preciso para poder inscribirse en este Registro el que vengan ejerciendo sus actividades desde antes de su solicitud de inscripción (como se decía expresamente en el Proyecto de Reglamento). Recelo que no termina de despejar la mención del art. 7.h), cuando exige la presentación de la Memoria anual correspondiente al último año de actividad, «si la tuviere». Adviértase que la declaración responsable que el Reglamento requiere en el apartado e) se encuentra más cerca de una memoria que de otra cosa, la cual, como es obvio, sólo puede elaborarse cuando la entidad haya estado activa y en funcionamiento. Por consiguiente, la misma prevención que se realiza en el inciso final del art. 7.h) debió realizarse respecto de su apartado e), pues de otro modo parece que de lo que se excusa es de presentar documentación, no de que la actividad deba de haberse realizado desde antes.

Por otra parte, no será inútil recordar que esa exigencia de que vinieren ejerciendo sus actividades con anterioridad es también, nuevamente, un requisito para la declaración de utilidad pública, siendo oportuno observar que algunas de las entidades más emblemáticas del sector, cuando han protocolizado en normas internas la incorporación a las mismas de nuevos miembros, han contemplado entre los requisitos de admisión que el aspirante debe cumplir unas exigencias análogas a las requeridas en la LODA para la declaración de utilidad pública, incluido ese período mínimo de dos años ${ }^{60}$.

60 Es el caso de CONGDE (Coordinadora de Organizaciones No Gubernamentales para el Desarrollo-España), que, según luce en el art. 8 de sus Estatutos, es «una asociación de entidades sin ánimo de lucro compuesta por Organizaciones No 
Desde esa perspectiva, pues, no puede sorprender la interpretación de quienes, a la vista de todo ello, consideran que no es necesario que estén declaradas de utilidad pública.

\section{III.H. Las ONGDs como entidades dotadas de una estructura estable}

La siguiente consideración que hemos de efectuar es que las ONGDs no son un tipo de persona ni constituyen una categoría jurídica en el sentido en que lo son las fundaciones o las asociaciones. La noción de ONGD, término que tuvo sus orígenes en la expresión contenida en el artículo 71 de la Carta de las Naciones Unidas de San Francisco de 26 de junio de 1945, constituye hoy más bien un concepto cultivado en el ámbito de las ciencias sociales y tomado en préstamo por nuestra legislación, con el que inicialmente, en un contexto en que las relaciones internacionales estaban dominadas por los Estados como casi exclusivos protagonistas, se enfatizaba el hecho de que las mismas ni son Estado ni son Organizaciones Intergubernamentales, no obstante a lo cual, se les reconoce como interlocutores a través de la concesión del estatuto de entidades consultivas ante diversos órganos de Naciones Unidas, señaladamente, del Consejo Económico y Social ${ }^{61}$. Así, se las describiría como entidades privadas, de creación y adhesión voluntarias, ligadas a la consecu-

Gubernamentales de diversa naturaleza jurídica, como asociaciones, fundaciones y otras previstas por la ley, así como de las Coordinadoras de Organizaciones No Gubernamentales de ámbito autonómico legalmente constituidas», en cuyo Reglamento de Procedimientos Internos establece que, entre otros documentos que han de acompañar para la solicitud de ingreso en la Coordinadora, las organizaciones aspirantes deben aportar: "Memoria de actividades correspondiente a los dos años anteriores a la solicitud de admisión que se presente y que deberá contener un listado de proyectos en los ámbitos de trabajo que, de conformidad con lo establecido en el artículo 10 de los Estatutos, se vinculan a la cooperación internacional para el desarroIlo, en los que se encuentra participando directamente en el momento de la solicitud, al objeto de reflejar la experiencia probada de la organización en el campo específico del desarrollo» (artículo 32.4). Cfr.: CONGDE, «Estatutos de la Coordinadora, Reglamento de Procedimientos Internos y Código de Conducta de las ONG de Desarrollo». Quinta edición: abril 2018 (formato digital), accesible en:

$<$ https:/coordinadoraongd.org/wp-content/uploads/2018/04/Estatutos_ Reglamento_CodigodeConducta_2018.pdf.> Fecha acceso doc.: 25/02/2019.

61 El referido artículo 71 de la Carta de Naciones Unidas dispone en ese sentido que «El Consejo Económico y Social podrá hacer arreglos adecuados para celebrar consultas con organizaciones no gubernamentales que se ocupen en asuntos de la competencia del Consejo. Podrán hacerse dichos arreglos con organizaciones internacionales y, si a ello hubiere lugar, con organizaciones nacionales, previa consulta con el respectivo Miembro de las Naciones Unidas». Vid. BOE núm. 275, de 16 de noviembre de 1990, en que se reproduce el texto de la Carta junto

(C) UNED. Revista de Derecho UNED, núm. 27, 2021 
ción de fines ideales muy diversos de alcance internacional, independientes del poder político y diferenciables de otros actores también privados por carecer de propósito lucrativo, respecto de las que, en lo que ahora nos interesa, ha de destacarse la necesidad de que poseyeran cierto grado de institucionalización, lo que las distingue de aquellos movimientos y agrupaciones de facto, no formalizadas y carentes de una estructura estable.

En ese sentido, cabía interpretar que la mención del apdo. $2^{\circ}$ del art. 32 de la Ley 23/1998 a que tuvieran una «estructura susceptible de garantizar suficientemente el cumplimiento de sus objetivos» hacía referencia precisamente a ese hecho: a que poseyeran una estructura corporativa a través de la cual se institucionalicen sus fines; id est, que la organización permanece con independencia de las incorporaciones o salidas de sus miembros o asociados. El Reglamento de 2015, en cambio, va más allá y mezcla la noción de «estructura» con otras exigencias, como la disposición de «medios materiales y per-

a la declaración unilateral española de 15 de octubre de 1990, en aceptación de la jurisdicción obligatoria del Tribunal Internacional de Justicia.

Debo señalar que el entendimiento del concepto de ONG contenido en el transcrito art. 71 experimentaría cierta evolución en posteriores resoluciones del Consejo Económico y Social de Naciones Unidas: Así, en la Resolución 288 (X), de 27 de febr. de 1950, se disponía que "Cualquier organización internacional no creada por vía de acuerdos intergubernamentales se considerará, a los efectos de los presentes arreglos, como organización no gubernamental», a lo que, posteriormente, en la resolución 1296 (XLIV), de 23 de mayo de 1968, se añadiría "... incluidas las organizaciones que acepten miembros designados por las autoridades gubernamentales, siempre que la existencia de tales miembros no coarte la libertad de acción ni la libre expresión de opiniones de la organización». Del mismo modo, su carácter internacional más que cifrarse en la pertenencia de sus miembros a varios países, pasaría a predicarse en función del alcance o proyección internacional de sus fines y actividades. Vid., ECOSOC (ONU) Res. 288 B (X) de 27 febr. 1950, Documentos oficiales: quinto año, décimo período de sesiones, 7 de febrero a 6 de marzo 1950, doc. E/1661, Resoluciones, suplemento n 1 , Lake Success, New York, 19 de abril de 1950, pág. 12 y ss.; ECOSOC (ONU) Res. 1296 (XLIV), de 23 de mayo de 1968, Documentos oficiales: $44^{\circ}$ período de sesiones, 6 a 31 de mayo de 1968, doc. E/4548, Resoluciones, suplemento ${ }^{\circ}{ }^{1}$, Lake Success, New York, 1968, pág. 21 y ss.; y ECOSOC (ONU) Resolución 1996-31, de 25 de julio, Documentos oficiales: Período de sesiones sustantivo de 1996, doc. E/1996/96, suplemento $n^{\circ} 1$, New York, 1997, pág. 57 y ss., relativas todas ellas a los arreglos para la celebración de consultas con las Organizaciones no gubernamentales, especialmente en lo que se refiere a los Principios que han de aplicarse para su celebración, la naturaleza de dichos arreglos y al establecimiento de relaciones consultivas con tales ONGs.

Véase también: ORTEGA CARPIO, $\mathrm{M}^{\mathrm{a}} \mathrm{L}$.: Las ONGD y la crisis del desarrollo. Un análisis de la cooperación con Centroamérica, IEPAIA Editorial, Madrid, 1994, en particular, su capítulo I: «La cooperación no gubernamental. Concepto y orígenes de los organismos no gubernamentales de desarrollo», pág. 39 y ss.; y SERRANO Caballero, E.: Las ONG como actores de las Relaciones Internacionales (tesis doctoral, UCM, 1999, págs. 17, 55, y 663). 
sonales "propios" que garanticen la sostenibilidad de las actividades que realiza ${ }^{62}$, lo cual, por otra parte, acaso pudiera tener algún sentido respecto de aquellas entidades cuya viabilidad no ha sido examinada por el Registro de fundaciones o por el Órgano competente para declarar su utilidad pública y verificar la rendición de cuentas, pero, desde luego, no parece lo más acertado respecto de las que ya se hayan sometido al control de la Administración competente previamente a la inscripción en el Registro de ONGDs, por cuanto podría suscitar evidentes conflictos interadministrativos ${ }^{63}$.

Por otro lado, se debe subrayar que la inscripción en el Registro de ONGDs carece por completo de naturaleza constitutiva. La personalidad de quienes accedan al mismo viene determinada no por esta inscripción - que tampoco sustituye a la que, en su caso, proceda realizar en el Registro pertinente de acuerdo con su naturaleza-, sino por el régimen jurídico que corresponda al tipo de entidad de que se trate: v.gr., con el otorgamiento del acta fundacional en el caso de las asociaciones: art. 5.4 LODA; con la inscripción en el Registro de fundaciones: art. 4 de la Ley 50/2002; con su acceso al Registro de Cooperativas en el caso de las cooperativas sin ánimo de lucro; etc. Del mismo modo, tampoco dicha inscripción suple, sino que se superpone a la del Registro de Asociaciones, la cual, aunque no constituye un requisito para que obtengan personalidad, como

62 No deja de ser revelador del propósito de trascender la noción del citado precepto legal, el hecho de que, entre otros documentos, el Reglamento exija en su artículo 7 que se acompañe a la solicitud de primera inscripción: «f) Certificado de la entidad en el que se acredite la existencia de estructura suficiente para garantizar los fines de la entidad»-que, como se vio, es a lo que se contrae el apdo. $2^{\circ}$ del art. 32 de la Ley 23/1998 - , lo que haría sobrar las otras exigencias reglamentarias. Adviértase que, según el mismo precepto, dicho certificado deberá contener al menos el organigrama de la entidad y sus delegaciones, el número de personas socias, el personal contratado y el número de voluntarios y cooperantes dedicados a las actividades relacionadas con la cooperación internacional para el desarrollo, pero sin hacer referencia a sus fuentes de financiación, cuyo detalle reclama luego en otro apartado distinto: el apartado g).

63 Todo ello, al margen de que los distintos requisitos exigidos por el Reglamento parecen pensados fundamentalmente para asociaciones, como delatan las distintas referencias a los «socios» y la ausencia de mención alguna sobre los patronos o fundadores; hecho que podría guardar cierta congruencia con la interpretación, sobre la que luego nos detendremos, de que se dirigen no tanto a las fundaciones y asociaciones declaradas de utilidad pública — que tendrían acreditado su cumplimiento y cabe argüir que disfrutarían de los beneficios fiscales de las entidades sin fin de lucro sin necesidad de invocar el art. 35 de la Ley 23/1998 - como a disciplinar a las asociaciones no declaradas de utilidad pública, lo que eludiría el problema apuntado en el texto -el eventual conflicto interadministrativo - y puntuaría a favor de la irrelevancia de dicha declaración respecto de las inscritas en el Registro de ONGDs: vid. infra, págs. 344, 345 y 348. Aunque, como luego se desvelará, mi criterio es diferente (vid., págs. 355 y ss.).

(C) UNED. Revista de Derecho UNED, núm. 27, 2021 
acaba de indicarse, sí deviene en condición necesaria para las declaradas de utilidad pública.

Corrobora esa «duplicidad» registral, entre otros, el art. 7.d) del propio Reglamento del Registro de ONGDs de 2015 que, entre la documentación que debe aportarse con la solicitud de primera inscripción, requiere que se adjunte "Certificado de inscripción en el registro público correspondiente en función de la naturaleza jurídica de la entidad». Exigencia introducida ex novo por el actual Reglamento en el anterior no era necesaria- y que, a mi juicio, resulta también cuestionable, salvo, acaso, respecto de las fundaciones y las cooperativas (en cuanto que para ellas, como acabo de señalar, sí es requisito para que adquieran personalidad jurídica y puede ser razonable que se les exija acreditar que la tienen), pero no respecto de las asociaciones $^{64}$, las cuales no deberían quedar excluidas por tal causa del efecto beneficioso - la publicidad formal- que pueda dispensarles la inscripción en el Registro de ONGDs.

Todo ello, con independencia de que, incluso para las que hayan de inscribirse necesariamente en otro Registro para adquirir personalidad jurídica u obtener la declaración de utilidad pública, la exigencia de registrarse también en el de ONGDs como condición indispensable para acceder al régimen de las ESFL con el consiguiente trato fiscal de favor no sólo para ellas mismas, sino también para sus donantes, se me antoje una exigencia que pudiera resultar contraria a Derecho - por redundante y, a la postre, obstaculizadora-, si es que no hubiere de estimarse superada con la dicción del art. 2.c) de la Ley 49/2002, conforme luego precisaré ${ }^{65}$.

En definitiva, si se me permite verbalizar la impresión que se colige de todo lo anterior, podría concluirse que frente a la necesidad de una interpretación abierta y no excluyente de las entidades susceptibles de inscripción en el Registro de ONGDs para dar plena satisfacción a lo que constituye el objetivo esencial del mismo - la publicidad-, se vislumbra en la regulación del actual Reglamento del Registro de la AECID cierto afán recentralizador, muy probablemente - y no lo planteo en términos negativos-, en línea con otras normas coetáneas, como la Ley de la Acción y del Servicio Exterior del Estado o la Ley de Tratados y otros Acuerdos Internacionales, como respuesta refleja a la creciente $-\mathrm{y}$ en ocasiones desconcer-

64 Recordemos nuevamente que para las declaradas de utilidad pública la inscripción en el registro de asociaciones tampoco es requisito para adquirir personalidad (todas la adquieren con el mero otorgamiento del acta fundacional), sino sólo para que puedan obtener dicha declaración: art. 32.1.e) LODA.

65 Vid. infra, pág. 339 y ss. 
tante- actividad internacional de las CCAA, así como al imparable protagonismo de las ONGDs, que de un papel prácticamente irrelevante han pasado a gestionar un cuantioso volumen de recursos con destino a la cooperación internacional, a lo que, justamente por ello, no resulta tampoco ajena la intención de favorecer a un determinado tipo de ONGDs, de carácter profesional, más orientadas a la prestación de servicios que al activismo y la participación y sensibilización políticas (de ahí los requisitos que adiciona), al tiempo que - tal vez como contrapartida ${ }^{66}$-, por un lado, busca clausurar la entrada en el "mercado» de subvenciones y ayudas públicas al desarrollo o, cuando menos, situar en desventaja - e incluso restar atractivo a su financiación privada, habida de que los recursos económicos, públicos y privados, son siempre escasos y la condición de ESFL es requisito para su consideración como «entidades beneficiarias del mecenazgo" con los consiguientes incentivos para sus benefactores- a otras ONGs "competidoras» que sólo tangencialmente tengan como fin la cooperación internacional o que puedan contar con otras vías de financiación merced a la participación en las mismas de las Administraciones o de otras entidades públicas, aunque ésta sea minoritaria y no decisiva; porfiando, por otro — enseguida veremos hasta qué punto con éxito-, en la sustitución de la declaración de utilidad pública por la de su inscripción en el repetido Registro estatal como condición indispensable para el disfrute del régimen fiscal de la Ley 49/2002, lo que, no se olvide, vale tanto como alejar de la órbita del Ministerio de Hacienda (cuyo criterio es determinante, no ya desde el punto de vista del alcance de dicho régimen tributario, como sería natural, sino habida cuenta de que su informe es preceptivo y además vinculante en el propio procedimiento de declaración de utilidad pública), resituándola en la del Ministerio de Asuntos Exteriores, más próximo, por razones obvias, a las ONGDs y, en principio, más sensibilizado que aquél en la cooperación internacional al desarrollo en términos de solidaridad no condicionada.

A lo que cabría añadir, en el mismo sentido, el juicio negativo que para cierto sector de las ONGDs tienen algunas de las exigencias de la declaración de utilidad pública, como es la rendición de cuentas en términos puramente contables y una llevanza de la contabi-

66 Aunque se trate, ciertamente, de una mera conjetura, se me antoja sintomático el voto favorable de la representación de las ONGDs en el Consejo de Cooperación al Desarrollo respecto del ya citado Informe sobre el Proyecto de Reglamento del Registro de ONGDs de la AECID elaborado por el Ministerio de Asuntos Exteriores y Cooperación, frente al voto particular de las Centrales sindicales en punto a los nuevos requisitos que éste exigía para ser reputadas ONGDs a efectos de su inscripción en dicho Registro (vid. supra, nota 60, párrafo $2^{\circ}$ ).

(C) UNED. Revista de Derecho UNED, núm. 27, 2021 
lidad que, además de sustraer recursos humanos y materiales de lo que constituyen sus fines, ha de efectuarse conforme a pautas traídas desde las entidades de mercado, donde es el beneficio el criterio en torno al que se organiza dicha llevanza y justificación, en lugar de un sistema de rendición basado, por ejemplo, en la evaluación de los impactos de su actividad respecto de los propósitos perseguidos con su realización.

Designios todos ellos que podrán o no compartirse, pero que, a mi juicio, requerían algo más que una mera norma reglamentaria, especialmente en lo que se refiere a los condicionamientos al régimen fiscal especial de la Ley 49/2002 por encima de su letra.

\section{LA INSCRIPCIÓN EN EL REGISTRO DE ONGDS COMO «CONDICIÓN (SUPUESTAMENTE) INDISPENSABLE» PARA EL DISFRUTE DEL RÉGIMEN FISCAL DE LA LEY 49/2002}

Como se ha venido señalando, el art. 33.2 de la Ley 23/1998 establece que la inscripción en los registros de ONGDs constituye una «condición indispensable» para que éstas puedan recibir de las Administraciones públicas, ayudas o subvenciones computables como ayuda oficial al desarrollo, así como para que "puedan acceder a los incentivos fiscales a que se refiere el artículo 35» de la misma Ley. Recordaré que este último artículo compendia el tratamiento fiscal de las ONGDs y de las aportaciones que se les realicen (mecenazgo), disponiendo - con las restricciones que enseguida veremos- no sólo la aplicación a las mismas del régimen fiscal especial de las ESFL o el de las entidades parcialmente exentas del IS respecto de las que no cumplan los requisitos para disfrutar de aquel régimen, sino que se detendrá también en los beneficios que, en su caso, podían disfrutar en el ITPyAJD o en el IVA.

Ahora bien, tras la aparente claridad y contundencia de dichos preceptos se esconden ciertas inconsistencias que, como tendremos ocasión de comprobar, nos enfrentará a diferentes maneras de interpretar su dictado, con importantes consecuencias prácticas. Veamos.

En primer lugar, antes de dar comienzo, es preciso tener en cuenta que, para la cabal comprensión de su alcance, tanto dicho art. 33.2 como el art. 35 a que remite han de leerse en el contexto de la Ley 30/1994, que era la norma vigente cuando se aprueba la Ley 23/1998, aunque sin perder de vista el ánimo diferenciador, reivindicativo de la particular idiosincrasia de estas entidades, que impregna esta última Ley. 
Como ya antes apunté, a diferencia de otras entidades, como las federaciones deportivas, las fundaciones extranjeras, las federaciones y asociaciones de entidades sin fin de lucro, etc., la Ley 30/1994 no contemplaba a las ONGDs, rectius: no las "visibilizaba» particularmente, porque era claro que podían disfrutar del régimen fiscal especial instituido por la misma cuando se constituyesen, como les es propio, con el designio de llevar a cabo actividades relacionadas con los principios y objetivos de la cooperación internacional para el desarrollo (recordemos, nuevamente, que la cooperación al desarrollo estuvo desde un inicio entre los fines de interés general expresamente incluidos entre los requisitos para disfrutar de dicho régi$m^{m e n}{ }^{67}$, siempre que lo hicieran, eso sí, bajo la forma de fundaciones o de asociaciones que fueren declaradas de utilidad pública —que son a las que el Legislador quiso ceñir el régimen especial— ${ }^{68}$. Pero adviértase igualmente que su situación no era distinta, por ejemplo, de la de las ONG de Acción Social (que hoy tienen reconocida su idiosincrasia en la Ley 43/2015, de 9 de octubre, del Tercer Sector de Acción Social) y a las que tampoco la Ley 30/1994 hacía alusión con ese nombre. Y no ofrece duda que, no obstante a ello, podían disfrutar del régimen fiscal que establecía cuando revistiesen dichas formas y cumpliesen los mismos requisitos.

No obstante, no puede sorprender que, en una norma como la Ley 23/1998, con un claro afán omnicomprensivo, que, como confiesa en su preámbulo, aspiraba a integrar en un único texto el conjunto de medidas e instrumentos que habían ido configurando la política de cooperación al desarrollo, revisando y actualizando todo el marco hasta entonces existente y redefiniendo los principios, objetivos y prioridades que inspiraban dicha política, no es de extrañar, decía, que el Legislador —el Gobierno, primeramente, que es de quien partía la iniciativa- estimase que, lejos de perturbar, resultaba conveniente, y hasta necesario para completar el sistema, incluir también los aspectos fiscales, a la par que otras medidas de fomento, incorporando una disposición como el art. 35, que, prima facie, parecía tener un carácter fundamentalmente "pedagógico», ya que se limitaba a reproducir — aparentemente sin innovar- lo que ya resultaba de la aplicación de las normas fiscales en aquel momento vigentes. Todo ello, si se me permite la maledicencia, al margen de la oportunidad política de «vender» — por segunda vez-

67 Cfr., art. 42.1.a) de la Ley 30/1994.

68 Recordemos que la cooperación al desarrollo estuvo contemplada, también de forma expresa, entre los fines que podían perseguir las fundaciones y las asociaciones de utilidad pública para poder ser consideradas como tales (art. $2.1 \mathrm{y}$ DA $13^{a}$ de la Ley 30/1994). 
unos beneficios que, según esta primera lectura, ya resultaban de la legislación en vigor, pero que, al no mencionar expresamente a las ONGDs, no resultaban «visibles».

En efecto, dejando para más tarde el análisis del primer apartado del referido artículo 35, toda vez que, en relación al mismo, ha de anotarse la diferencia relativa a la reiteración del deber de encontrarse inscritas en los Registros de ONGDs (de la que, como luego se dirá, cabría inferir con algún fundamento la idea de que en él subyace la pretensión de equiparar las ONGDs «inscritas» a las fundaciones y a las asociaciones declaradas de utilidad pública, aunque aquéllas carezcan de tal declaración), los restantes apartados de dicho artículo 35 parecen, a priori, respaldar la conclusión de que dicho precepto no vino sino a confirmar la normativa tributaria entonces vigente, sin alteración alguna de nuestro Ordenamiento fiscal más allá de la labor cosmética de acentuar la notoriedad de los beneficios que podían afectarlas, pero sin consecuencias reales y efectivas en el plano jurídico.

Así se desprendería de la lectura de su apartado 2, relativo a la «exención subjetiva» prevista en la letra c) del art. 45.I.A) del TRITPyAJD a favor de las "asociaciones declaradas de utilidad pública» ${ }^{69}$, que, lejos de modificar para que alcanzase a todas las ONGDs o, cuando menos, a todas las ONGDs a las que fuera aplicable el régimen de las ESFL, se limitaba a confirmar su procedencia respecto de "las entidades contempladas en el mismo» - por consiguiente, sólo respecto de las asociaciones que ostentasen dicha calificación-, sin hacer mención alguna a su inscripción en el Registro de ONGDs - ni siquiera para ratificar la referencia general que más atrás realizaba el art. 33.2, análogamente a como sucede en su párrafo primero- ${ }^{70}$, especificando, simplemente, que dicha exención les resultaba aplicable cuando realizasen las «actividades» que mencionaba el citado art. 45.I.A).c) «en el marco de la cooperación al de-

69 Téngase en cuenta que respecto de las fundaciones (y «establecimientos») era el apartado b) de dicho art. 45.1.A) el que establecía su exención cuando gozasen de la clasificación de benéficas o culturales, de previsión social, docentes o de fines científicos, de carácter particular. Pero el art. 35.2 de la Ley 23/1998 no se refería a dicho apartado, sino al c).

70 Lo que, en suma, parece contradecir la idea de que la Ley 23/1998 pretendía asimilar el tratamiento fiscal de las ONGDs constituidas como asociación e inscritas en el Registro de la AECID (o en su correspondiente homólogo autonómico), al de las fundaciones y asociaciones de utilidad pública, aunque aquéllas no contasen con dicha declaración. 
sarrollo». Precisión que también cabe negar que supusiera realmente innovación alguna ${ }^{71}$.

En efecto, aunque, en rigor, dicho art. 45.I.A).c) no se refería a "actividades»" ${ }^{72}$, sino más bien al tipo de "fines» a que debían dedicarse dichas asociaciones para estar exentas, lo que, dado el carácter «subjetivo» que se predicaba de la misma, podía dar pie a interpretar que antes de la Ley 23/1998 dicha exención sólo afectaba a las que hoy llamaríamos "entidades del Tercer Sector de Acción Social» (TSAS), siempre que tuvieran la forma jurídica de asociación y estuvieren declaradas de utilidad pública, pero no a las ONGDs aunque tuviesen la misma forma y condición, considero, sin embargo, que no hay méritos en el precepto para establecer tal distinción.

Adviértase que si bien es cierto que los fines que consignaba el citado artículo del TRITPyAJD eran fines «sociales», no es menos cierto que el componente «internacional» que caracteriza la cooperación para el desarrollo no excluye su carácter social: las referencias a la «mejora en el nivel de vida de las poblaciones beneficiarias, en general, y de sus capas más necesitadas, en particular» ${ }^{73}$; el objetivo de luchar contra la pobreza en todas sus manifestaciones, orientándose prioritariamente a sectores como los servicios sociales básicos ${ }^{74}$, velando por la accesibilidad universal de las personas con discapacidad ${ }^{75}$ o la defensa de los grupos de población más vulnerables (con expresa mención, entre otros, a los menores y a la infancia $)^{76}$, evidencian claramente sus afinidades y coincidencias ${ }^{77}$.

71 A lo más, siguiendo esta línea discursiva, cabría reputarla como una aclaración más bien didáctica o, si se prefiere, ad cautelam, frente a posibles interpretaciones restrictivas que pretendieran despojar a las ONGDs de dicho beneficio, pese a entrar en el ámbito de la exención.

72 El citado artículo 45 TRITPyAJD disponía literalmente: «1. A) Gozarán de exención subjetiva: [...] c) Las asociaciones declaradas de utilidad pública dedicadas a la protección, asistencia o integración social de la infancia, de la juventud, de la tercera edad, de personas con minusvalías físicas o psíquicas, marginadas, alcohólicas, toxicómanas o con enfermedades en fase terminal con los requisitos establecidos en el apartado b) anterior»; requisitos que se referían la gratuidad de los cargos y a la rendición de cuentas y, en el aspecto formal, a su sujeción al procedimiento reglamentario de concesión, que se regularía en el art. 89 del Reglamento del ITPyAJD, aprobado por el RD 828/1995, de 29 de mayo.

73 Art. 3 de la Ley 23/1998.

74 Art. 7.a) de la Ley 23/1998.

75 Art. 7.c) de la Ley 23/1998.

76 Ibidem.

77 Otra cosa es que los fines concretamente enunciados en el art. 45.1.A).c) no alcancen a todos los que eventualmente pueden caber bajo el rótulo de cooperación para el desarrollo. Piénsese, por ejemplo, en la protección y mejora de la calidad del medio ambiente, contemplado entre las prioridades sectoriales de la cooperación internacional (art. 7 de la Ley 23/1998), que, claramente, rebasa el perímetro de 
En otras palabras, en mi sentir, la alusión al desempeño de las actividades descritas en dicho artículo "en el marco de la cooperación al desarrollo» no añadía nada nuevo al presupuesto de hecho exento, pues el mismo no imponía ningún concreto «marco de referencia».

En todo caso, la situación cuando variaría, verdaderamente, es con la Ley 49/2002. Su DA $3^{a}$ modificaría dicho art. 45.I.A), de manera que la exención se reconocería a favor de las entidades sin fin de lucro acogidas a su régimen y sin referencia a unas concretas actividades, a marco alguno, ni a ninguna otra condición más que la de tratarse de entidades sin fin lucro que hubieran optado por dicho régimen. Por consiguiente, alcanzaría tanto a las ONGDs que fueran asociaciones declaradas de utilidad pública como a las que fuesen fundaciones y, dentro de éstas, no sólo a aquellas susceptibles de ser clasificadas como benéficas, culturales, etc., sino a todas sin distinción de clase, en cuanto todas han de perseguir fines de interés general y el Legislador no discriminaría entre unos u otros. En definitiva, a raíz de la Ley 49/2002, el precepto ha variado sustancialmente tanto su ámbito subjetivo como material. Todo lo cual pone de manifiesto no ya la ausencia en la Ley 23/1998 de una voluntad clara de alterar el estatus jurídico fiscal preexistente en lo que concernía al ITPyAJD, sino, además, que su dicción ha sido superada por la posterior Ley 49/2002, de manera que, aun en el supuesto de que hubiéramos de considerar que el apartado 2 del art. 35 de la Ley 23/1998 conserva alguna suerte de vigencia, es a la Ley 49/2002 a la que, evidentemente, habrá de estarse tanto para determinar quienes ostentan la condición de entidades sin fin de lucro, como para dilucidar si la inscripción a que alude de forma general, no el apartado 2 de dicho 35, sino el art. 33.2, resulta aún de algún modo exigible. Cuestión sobre la que, a fin de evitar reiteraciones, me remito a lo que luego se dirá respecto del apartado 1 del repetido artículo 35, en cuanto que, a propósito del mismo, se analizarán las exigencias de la Ley 49/2002 a este respecto.

En cuanto al IVA, también sería objeto de atención por la Ley 23/1998, aunque con resultado no muy distinto. El art. 35.3 otorgaría la consideración de «actividades de asistencia social», a efectos de disfrute de la exención del art. 20, Uno, $8^{\circ}$, de la LIVA ${ }^{78}$, a las ac-

la exención. Ahora bien, como se ha indicado en el texto, el artículo 35.2 de la Ley 23/1998, en una línea claramente continuista tanto en el aspecto subjetivo como en el material, no amplía su ámbito, sino que subraya que ésta resulta aplicable sólo en relación a las actividades enunciadas en la letra c) del art. 45.1.A).

78 Ley 37/1992, de 28 de diciembre, del Impuesto sobre el Valor Añadido. BOE núm. 312, de 29 de diciembre (LIVA). 
tividades de cooperación para el desarrollo que menciona en su art. $9^{79}$. Pero, en rigor, este art. 35.3 (al margen de que se refiere sólo a las actividades y no a que se las considerase «entidades de carácter social $^{80}$, como hubiera sido más lógico si hubiera querido supeditarse el beneficio a la inscripción), resulta también superfluo en este particular desde el momento en que su DA $2^{\mathrm{a}}$ ya procedía a modificar dicho art. 20, Uno, $8^{\circ}$, al objeto de incorporar una nueva letra a la relación de servicios de asistencia social exentos de dicho impuesto: «l) Cooperación para el desarrollo», sin que, a mi juicio, se superponga la exigencia de estar inscritas en el Registro de ONGDs para que sus actividades alcancen dicha consideración o para que puedan ser calificadas como «entidades de carácter social»; calificación a la que, como dije, ni siquiera se refiere.

Por lo que respecta al IS, el art. 35.5 disponía que para aquellas ONGDs que no cumplan los requisitos del capítulo I del título II de la Ley 30/1994 el régimen tributario aplicable a las mismas sería el del capítulo XV de la Ley 43/1995; esto es, el de las entidades parcialmente exentas del IS, ahora regulado en el capítulo XIV del título VII de la Ley 27/2014, de 27 de noviembre, del Impuesto sobre Sociedades $^{81}$; conclusión que se sigue alcanzando con la Ley 49/2002,

79 En puridad, el citado artículo 9 de la Ley 23/1998 se limita a enumerar una serie de instrumentos de la política española de cooperación internacional al desarrollo, que posteriormente desarrolla en los sucesivos artículos que componen el capítulo II de la Ley. Por consiguiente, ha de estarse más bien a los respectivos preceptos en que dichos instrumentos se describen, señalando su ámbito y manifestación. Los instrumentos a que se refiere dicho art. 9 son: a) La "cooperación técnica», que se define en el artículo 10 como "cualquier modalidad de asistencia dirigida a la formación de recursos humanos del país receptor, mejorando sus niveles de instrucción, adiestramiento, cualificación y capacidades técnicas y productivas en los ámbitos institucional, administrativo, económico, sanitario, social, cultural, educativo, científico y técnico»; b) La "cooperación económica y financiera», que se expresa, según se establece en su art. 11, a través de aportaciones destinadas a proyectos de inversión para el aumento del capital físico de los países beneficiarios y a proyectos de ayuda a los sectores económicos, así como a través de contribuciones oficiales a organismos internacionales, acuerdos financieros de alivio o condonación de deuda y otros préstamos o ayudas; c) La "Ayuda humanitaria», que, según su art. 12, comprende tanto la alimentaria como la de emergencia, incluyendo operaciones de mantenimiento de la paz; y d) la "educación para el desarrollo y sensibilización social», que incluye diversas acciones (campañas de divulgación, servicios de información, programas informativos, etc), orientadas, conforme señala el art. 13, a promover la percepción de la sociedad hacia los problemas que afectan a los países en desarrollo y que estimulen la solidaridad y cooperación activas con los mismos.

80 Vid. el art. 20. Tres de la LIVA y art. 6 del Reglamento del Impuesto sobre el Valor Añadido, aprobado por el RD 1624/1992, de 29 de diciembre (BOE núm. 314, de 31 de diciembre).

81 BOE núm. 288, de 28/11/2014. 
pero que, en todo caso, no es ni era resultado del mandato de este art. 35 de la Ley 23/1998, sino, en aquel entonces, del art. 133 de la citada Ley 43/1995 y, hoy, de los arts. 9.3.a) y 109 de la Ley 27/2014. En definitiva, también en este punto el precepto parece completamente superfluo, y el mandato a que ha de atenderse es al de la Ley 27/2014, sin que resulte de recibo que la aplicación del régimen fiscal especial de las entidades parcialmente exentas dependa de que así lo hubiera dispuesto dieciséis años atrás el art. 35.5 de la Ley 23/1998 y no la posterior y específica Ley del Impuesto sobre Sociedades. Como tampoco, por igual motivo, que su aplicación haya de entenderse condicionada a que estuvieran inscritas en el Registro de la AECID (o en los autonómicos), de manera que, en otro caso, hubieran de aplicar el régimen general del IS ${ }^{82}$.

82 Es oportuno apostillar que el art. 35.5 de la Ley 23/1998 traía causa de la enmienda núm. 347 del Grupo Parlamentario CiU en el Congreso, dirigida a añadir un nuevo apartado 5 al entonces artículo 31 del Proyecto de Ley de Cooperación Internacional para el Desarrollo con el propósito - según se alegaba en la Justificación de la enmienda- de que «[a]l igual que ocurre con las Fundaciones y Asociaciones declaradas de utilidad pública y sin ánimo de lucro, las ONG de desarrollo que no cumplan con los requisitos previstos en la Ley 30/1994 [tributen] por el régimen fiscal de entidades parcialmente exentas que prevé el Impuesto sobre Sociedades» (vid., BOCG, VI Legislatura, serie A, núm. 81-1, de 16 de septiembre de 1997, pág. 9, artículo 31, en lo que se refiere al Proyecto de Ley, y BOCG, VI Legislatura, serie A, núm. 81-7, de 17 de noviembre de 1997, pág. 142, respecto de la enmienda núm. 347). Pues bien, según resulta del informe de la Ponencia, la citada enmienda del Grupo catalán sería aceptada (junto a las núms. 345 y 346, formuladas también por dicho Grupo sobre este mismo artículo) y su texto pasaría al Dictamen de la Comisión de Asuntos Exteriores y luego a la Ley, aunque con una sutil, pero importante diferencia: en la citada enmienda la aplicación del régimen especial de las entidades parcialmente exentas del IS se predicaba de las "inscritas en cualquiera de los registros a que se refiere el artículo 29 de la presente Ley» - artículo 33 en el texto legal aprobado-, "cuando no cumplieran los requisitos exigidos en el Capítulo I del Título II de la Ley 30/1994». Sin embargo, tanto en el texto del Dictamen como en la Ley el inciso en cursiva no figura (vid. el Informe de la Ponencia y el Dictamen de la Comisión en BOCG, VI Legislatura, serie A, núm. 81-10, de 30 de marzo de 1998, págs.175-176, y núm. 81-12, de 22 de abril de 1998, pág. 205, respectivamente). Omisión que no dejaba de plantear la duda de si con ello la aplicación de dicho régimen fiscal especial ya no dependería de que se encontraran inscritas en dichos Registros (de manera que también a las no inscritas en aquéllos les resultaría aplicable cuando no pudieran disfrutar del régimen de las entidades sin fin de lucro) o si, contrariamente, había de interpretarse que seguían sin poder aplicar el de las entidades parcialmente exentas habida cuenta de que, aunque la referencia al deber de estar inscritas ya no luciese en el apartado 5, la dicción literal del art. 33.2 de la Ley (art. 29.2 del Proyecto), continuaba estableciendo que «dicha inscripción será también necesaria para que las organizaciones no gubernamentales de desarrollo puedan acceder a los incentivos fiscales a que se refiere el artículo 35» (art. 31 del Proyecto), entre los que se encontraría la aplicación del «régimen especial de las entidades parcialmente exentas» frente al "régimen general» que correspondería en otro caso. Incertidumbre que cabría despejar — al margen de por lo señalado en el 
Por su parte, ya en el ámbito del mecenazgo, el apartado 4 del artículo 35 se limitaría a expresar, en términos aparentemente tautológicos ${ }^{83}$, que las aportaciones realizadas a las ONGDs «incluidas en el ámbito de aplicación de la Ley 30/1994» —las cuales, por consiguiente, tendrían, en principio, el carácter de entidades sin fin de lucro--, darían derecho a disfrutar de los incentivos previstos en dicha Ley para las aportaciones efectuadas a... las entidades sin fin de lucro, que así es como se rubricaba el capítulo II de su Título II a que remitía dicho art. 35.4: «Régimen tributario de las aportaciones efectuadas a entidades sin fines lucrativos». Por consiguiente, bajo esta perspectiva, no se estaba creando ningún incentivo que anteriormente no existiera ${ }^{84}$.

texto en punto a que el supuesto ha de entenderse regido por la Ley 27/2014, que es posterior y específica- en el sentido de que la exigencia del último inciso del repetido art. 33.2 (de considerarse éste vigente, lo que cabe cuestionar: vid., infra, págs. 340-341), sólo vale, en verdad, para los incentivos fiscales del régimen especial de las entidades sin fin de lucro, esto es, que la remisión ha de entenderse realizada exclusivamente al apartado primero del art. 35; hipótesis que podría ser aceptable teniendo en cuenta que es el único que repite la necesidad de que estén «inscritas en los Registros a que se refiere el artículo 33». En todo caso, las consideraciones que luego se harán respecto del art. 35.1 valen para el resto de apartados, incluido éste.

83 Enseguida explicaré por qué digo «aparentemente».

84 No obstante, es necesario aclarar que ésta es solo una de las interpretaciones posibles y que lo que a priori parece una obviedad encuentra distintas explicaciones que contradicen el carácter aparentemente "tautológico» de dicho apartado e incluso la propia conclusión que se alcanza al entenderlo de esa forma.

La primera de dichas explicaciones pasaría por señalar que dicha redacción fue consecuencia de que inicialmente el Proyecto de Ley se refería sólo a los arts. 59 a 65 de la Ley 30/1994. La enmienda del Grupo Parlamentario Catalán CiU núm. 346 se dirigiría, justamente, a instar la modificación de dicho precepto - que en el Proyecto era el art. 31.4- para que la referencia incluyera también los artículos del 66 a 68, relativos a la justificación de los donativos (art. 66), a las actividades y programas prioritarios de mecenazgo (art. 67) y a los convenios de colaboración empresarial en actividades de interés general (art. 67), todos ellos comprendidos también en la misma sede. De ahí que se instase a que la remisión del apartado se hiciera a todo el Capítulo II del Título II de la Ley 30/1994 (es decir, a los art. 59 a 68) con el objeto, según se justificaba en la enmienda, de «Equiparar plenamente los incentivos previstos en el presente Proyecto de Ley para las aportaciones efectuadas por personas físicas y jurídicas a Organizaciones no Gubernamentales de Desarrollo a los que la Ley 30/1994 contempla para las fundaciones y asociaciones declaradas de utilidad pública». Aceptada la enmienda, el art. 31.4 del texto del Dictamen emitido por la Comisión de Asuntos Exteriores sobre el Proyecto de Ley recogería ya dicha redacción, que pasaría al art. 35.4 de la Ley 23/1998. Vid., BOCG, VI Legislatura, serie A, núm. 81-1, de 16 de septiembre de 1997, pág. 9, artículo 31, en lo que se refiere al Proyecto de Ley; núm. 81-7, de 17 de noviembre de 1997, pág. 142, respecto de la enmienda 346 del Grupo Parlamentario Catalán CiU; y núm. 8112, de 22 de abril de 1998, pág. 205, artículo 31, en lo referente al Dictamen de la Comisión de Asuntos Exteriores.

Pero lo que ahora nos interesa volver a poner de relieve, más allá del concreto origen de dicha redacción, es que con ella se evidenciaría que tanto en el Proyecto

(C) UNED. Revista de Derecho UNED, núm. 27, 2021 
En el mismo sentido, aunque ya fuera del precepto que venimos examinando, cabría traer a colación el art. 36 de la misma Ley, en cuanto prevenía la posibilidad de que las Leyes anuales de Presupuestos incluyeran determinadas actividades o programas realizados en el marco de la cooperación para el desarrollo entre las actividades y programas prioritarios de mecenazgo, a los efectos de la aplicación de los incentivos fiscales incrementados a que se refería el art. 67 de la Ley 30/1994; previsión ésta que resultaba también perfectamente innecesaria, sin otro objeto que el de celebrar como nuevo el potencial incremento de unos incentivos que, en puridad, ya tenían abierta desde atrás dicha posibilidad, dado que, conforme a dicho art. 67, las actividades y programas prioritarios de mecenazgo habían de llevarse a cabo «en el ámbito de los fines citados en el artículo 42.1, a)» de la Ley 30/1994, entre los que ya se encontraban los de «cooperación para el desarrollo».

Finalmente, el último apartado del reiterado art. 35, el apdo. 6, tampoco representaba cambio alguno, ya que se limitaba a disponer que «La presente regulación de incentivos fiscales se entiende sin

de Ley como durante la tramitación parlamentaria latía intensamente la idea de que las ONGDs eran una categoría diferente de las ESFL (sobre esto, véase también infra, pág. 336) y que por ello era preciso «equipararlas». Nótese que si ya «son» entidades sin fin de lucro, no tiene sentido dicha «equiparación» y hasta la propia existencia del artículo 35.4 resulta innecesaria —a lo sumo, tendría un carácter didáctico- como ya se sugirió en el texto. Todo lo cual enlaza con la segunda de las interpretaciones a que antes aludía.

En efecto, la segunda de las interpretaciones partiría de considerar que la criticada "tautología», en rigor, solo sería tal si se admite apriorísticamente rectius: si se estima erróneamente-que el inciso «incluidas en el ámbito de aplicación de la Ley 30/1994» está limitando su campo a las que ostenten el carácter de entidades sin fin de lucro. Pero debe considerarse que eso no es así y que entidades distintas de las "entidades sin fin de lucro» - a saber, que entidades diferentes a las fundaciones y a las asociaciones declaradas de utilidad pública, con las que, en principio, se agota dicha categoría tributaria si atendemos a su art. 41 - pueden, sin embargo, quedar incluidas en el ámbito de aplicación de dicha Ley sin ostentar propiamente dicha condición: sería el caso de algunas de las entidades que se mencionan en las disposiciones adicionales, particularmente, en la disposición adicional sexta que, precisamente, establecía que el régimen previsto en los artículos 59 a 68, ambos inclusive, sería aplicable a los donativos efectuados y a los convenios de colaboración celebrados con las entidades que se citaban en la misma (Cruz Roja, ONCE, Confesiones Religiosas, Instituto de España, Reales Academias...), las cuales en la filosofía de la Ley 30/1994 no son propiamente entidades sin fin de lucro, sino entidades "asimiladas» a las que se aplica su régimen, y a las que, merced a este art. 35.5, en conexión con el apartado 1 de dicho mismo precepto, se sumarían las ONGDs, lo que añadiría un nuevo argumento en la polémica sobre la necesidad o no de la declaración de utilidad pública en el caso de las ONGDs constituidas como asociaciones. No obstante, en relación con el apartado 1 del art. 35, a cuya luz habría de leerse este apartado 4 para llegar a esa conclusión, véase lo que se dice más adelante en las págs. 339 y ss. 
perjuicio de la que puedan establecer otras Administraciones públicas en virtud de la normativa vigente y sus competencias en la materia»; precepto cuyo carácter meramente clarificador o, si se prefiere, de simple salvaguarda, no precisa mayor comentario ${ }^{85}$.

En definitiva, esta primera lectura del art. 35 nos llevaría a concluir que, con la salvedad de su primer apartado, a que enseguida me referiré, los restantes se habrían limitado a poner en valor la existencia de los incentivos fiscales que rememoran, confirmando la normativa tributaria entonces aplicable a estas entidades, sin que resulte concluyente para su disfrute - a pesar de la contundencia de su letra- la obligatoriedad de la inscripción en el Registro de ONGDs a que se refiere el art. 33.2 como "condición indispensable», la cual, al margen de la ayuda oficial al desarrollo, habría que entenderse referida más bien al apartado 1 del art. 35, que asigna el régimen tributario de las entidades sin fines lucrativos sólo a las ONGDs «inscritas en los Registros» a que se refiere su artículo 33, si es que uno y otro preceptos pueden considerarse vigentes tras la Ley 49/2002.

En efecto, como he venido señalando, la exigencia de inscripción en el/los Registros de ONGDs se presta a diversas interpretaciones que irían: desde la consideración de que, tras la Ley 49/2002, ni uno ni otro artículos pueden estimarse vigentes y que, por tanto, tal inscripción no sólo es voluntaria - que ya lo era, en todo caso, conforme a la propia Ley $23 / 1998^{86}$ - , sino que tampoco condiciona ya el disfrute de los incentivos que menciona en su art. $35^{87}$, hasta llegar, en el otro extremo, a su entendimiento en términos rigurosos e imperativos, en consonancia no sólo con su letra, sino con las pro-

85 Recordaré solamente, a efectos puramente ilustrativos, que inicialmente este precepto no figuraba en el Proyecto de Ley remitido por el Gobierno, sino que fue fruto de la enmienda de adición presentada por el Grupo Parlamentario Vasco (EAJ-PNV), bajo el núm. 71, con el propósito de hacer valer las competencias tributarias y fiscales de los Órganos Forales de los Territorios Históricos, con el siguiente tenor: "La presente regulación de incentivos fiscales se entiende sin perjuicio de la que puedan establecer los Órganos Forales de los Territorios Históricos de la Comunidad Autónoma del País Vasco y la Comunidad Foral de Navarra en virtud de sus competencias en la materia». Dicha enmienda sería aceptada en el Informe de la Ponencia, pasando a convertirse en el apartado 6 de dicho artículo 35, pero con el tenor más general que se reproduce en el texto. Vid., BOCG, VI Legislatura, serie A, núm. 81-1, de16 de septiembre de 1997, pág. 9, artículo 31, en lo que se refiere al Proyecto de Ley; BOCG, VI Legislatura, serie A, núms. 81-7, de 17 de noviembre de 1997, pág. 73, respecto de la enmienda núm. 71 del Grupo Parlamentario Vasco; y BOCG, VI Legislatura, serie A, núms. 81-10, de 30 de marzo de 1998, págs.175-176, en cuanto al Informe de la Ponencia).

86 Vid., el art. 33.1 de la Ley 23/1998: "podrán inscribirse» y el comentario sobre sus antecedentes parlamentarios en la nota 102.

87 Véase., infra, pág. 339 y ss. 
pias manifestaciones del Legislador de la Ley 23/1998, que, según esta otra lectura, sí habría ido más lejos de la «visibilización» de los beneficios fiscales con que ya contaban o de su mera recopilación con una finalidad puramente aclaratoria o didáctica, requiriendo su cumplimiento por todas las ONGDs, sin excepción, en tanto que «condición indispensable» para el disfrute de los repetidos incenti$\operatorname{vos}^{88}$, pasando, en fin, en un postrero esfuerzo hermenéutico, por estimar que la intención del art. 33.2 no habría sido la de privar de los mismos a las fundaciones y asociaciones de utilidad pública que, gozando ya de ellos, no se inscribieran en el Registro/s de ONGDs, sino que, antes al contrario, obedecería al propósito de posibilitar que, mediante su inscripción en el mismo/s, pudieran disfrutar también de dichos incentivos fiscales aquellas otras ONGDs que no ostentaran aquella naturaleza o condición, lo que, en suma, restringe el alcance de dicho requisito ${ }^{89}$.

Pues bien, la primera apreciación que cabe formular en relación a esa diversidad es que del examen de los documentos y debates parlamentarios de la Ley 23/1998 se observa que, tal vez como consecuencia de haber tenido que definir lo que había de entenderse por ONGD, sus autores estimaron que con ello habían "construido" jurídicamente una «nueva» categoría de entidades, para las que, en tanto que nuevas, era necesario decidir — su Exposición de Motivos hablaba de «establecer»- el régimen fiscal que habría de aplicárseles (lo que hicieron atribuyéndoles el de las entidades sin fin de lucro de la Ley 30/1994), dado que, de otro modo - debieron pensar-, hubieran quedado fuera de los beneficios fiscales que correspondían a éstas ${ }^{90}$. Recuérdese en este sentido que el concepto de ONGDs es

88 Vide, infra, pág. 346 y ss.

89 Vid., infra, pág. 344 y ss.

90 Lo que resulta desconcertante es que, posteriormente, a propósito del primer Reglamento del Registro de ONGDs, el Consejo de Estado tampoco estuviese muy atinado sobre este particular, llegando a considerar que, por mor del art. 35 de la Ley 23/1998, el régimen fiscal de las entidades sin fin de lucro sólo correspondía a las ONGDs que estuvieran constituidas como fundaciones ( $\dot{\complement}$ !), sin perjuicio de que las constituidas como asociaciones pudieren obtener ayudas y subvenciones -que no disfrutar del referido régimen fiscal - al amparo del art. 34 de la misma Ley:

«El artículo 6 -diría el Consejo de Estado en su dictamen sobre el Proyecto de Real Decreto por el que se aprobaría el Reglamento del Registro de ONGDs de 1999-, parece partir de la idea de que las ONGD que accedan al Registro regulado son "fundaciones". Así podría deducirse de los párrafos e), g) y, sobre todo, h) del apartado 2. Sin embargo, el artículo 32 de la Ley 23/1998 formula un concepto amplio de las ONGD pues dice que, a sus efectos, "se consideran organizaciones no gubernamentales de desarrollo aquellas entidades de Derecho privado, legalmente constituidas y sin fines de lucro, que tengan entre sus fines o como objeto expreso, según sus propios Estatutos, la realización de actividades relacionadas con los 
más amplio, abarca más entidades que las que caben en el de «entidad sin fin de lucro» (constreñido, en el momento de aprobarse la Ley 23/1998, a las fundaciones y las asociaciones de utilidad pública), por lo que evidentemente no todas habrían quedado cubiertas, lo que respaldaría la necesidad de «establecer» el régimen fiscal que había de aplicárseles ${ }^{91}$.

Abona la misma idea el hecho de que el art. 35.1 de la Ley 23/1998 no diga que las ONGDs inscritas en los Registros a que se refiere en su artículo 33 tendrían la consideración de entidades sin fines lucrativos, sino que les resultará aplicable el régimen tributario de las entidades sin fines lucrativos regulado en la Ley 30/1994, lo que

principios y objetivos de la cooperación internacional para el desarrollo". El artículo 35 de la misma Ley distingue, incluso, en cuanto al régimen tributario aplicable a las ONGD, el de aquellas que revistan la forma jurídica prevista en la Ley 30/1994, de 24 de noviembre (apartado 1), y el de aquellas que no cumplan los requisitos exigidos en tal regulación (apartado 5). Y, aunque el tratamiento fiscal privilegiado se refiera exclusivamente a las primeras (esto es, a las fundaciones) [ $\dot{c} !]$ a tenor del artículo 35.1, nada impide que puedan obtener ayudas y subvenciones públicas aquellas ONGD que no estén constituidas como fundaciones (artículo 34), por lo que, siendo en todo caso condición para poder percibir éstas la inscripción en el Registro adscrito a la AECI, el artículo 6 de su Reglamento no ha de ser restrictivo en su redacción, debiendo en consecuencia referirse genéricamente a las ONGD, sin sugerir que se consideran en particular o como tipo las constituidas bajo la forma jurídica de "fundaciones"». [Dictamen del Consejo de Estado de 6 de mayo de 1999, sobre el Proyecto de Real Decreto por el que se aprueba el Reglamento del Registro de Organizaciones no gubernamentales para el desarrollo, núm. de expediente 992/1999 (Asuntos Exteriores y de Cooperación), apdo. V, observaciones al artículo 6, última página. La cursiva y destacados son míos].

Sinceramente, no acierto a encontrar explicación de por qué el Alto órgano consultivo obvió a las asociaciones de utilidad pública, porque aunque la rúbrica de la Ley 30/1994 mencione sólo a las fundaciones, la remisión del art. 35.1 de la Ley 23/1998, como ya expliqué, lo es no a su Título I (fundaciones), sino al Título II (Incentivos fiscales a la participación privada en actividades de interés general), concretamente a su capítulo I (Régimen tributario de las entidades sin fines lucrativos), cuyo primer artículo (el art. 41: Definición de entidades sin fines lucrativos a efectos del presente Título) preceptúa claramente que por tales se ha de entender tanto las fundaciones inscritas en el Registro correspondiente como las asociaciones declaradas de utilidad pública que cumplan los requisitos establecidos en ese Título.

91 No obstante, a este respecto cabría replicar que el propio Legislador abandona enseguida dicho concepto a efectos fiscales y opta por atribuir analíticamente los beneficios del régimen de las entidades sin fin de lucro no a todas las ONGDs, ni siquiera a todas las inscritas en el Registro de la AECID, sino sólo a las que tuvieran la misma forma jurídica y cumplieran los mismos requisitos que las protagonistas de dicho régimen, de manera que se trataría de las mismas entidades, solo que contempladas desde distinta perspectiva: en la Ley 30/1994 poniendo el foco en la forma y los fines y en la Ley 23/1998 remarcando la especificidad de los fines y la forma, pero, en definitiva, las mismas. Más tarde abundaremos en esta crítica. 
no es exactamente lo mismo: no se las identifica ni se las reduce a ser una simple variante o modalidad de entidad sin de lucro (a diferencia, por cierto, de lo que cabría predicar tras la Ley 49/2002), sino que, manteniendo su identidad como «nueva» categoría en mérito de su particular idiosincrasia (la especificidad de sus fines, el contexto en que se produce su actividad, los destinatarios a quienes se dirigen, el ideario en que se inspiran... ${ }^{92}$ ) se les atribuye el régimen previsto para «otras» entidades - las ESFL - con las que guardarían una evidente proximidad, incluso una parcial coincidencia, pero con las que no se quiere que se confundan, lo que en términos jurídicos significaría tanto como que dicho art. 35.1 quiso sustraerlas del ámbito de la Ley 30/1994, sin perjuicio de que luego se remitiera a ella.

En este sentido, adviértase que las dos últimas interpretaciones a que me he referido anteriormente compartirían la conclusión de que bajo el primer apartado del repetido artículo 35, e incluso en el inciso segundo del art. 33.2, late el designio de equiparar las ONGDs «inscritas» en el Registro de la AECID (o en su correspondiente autonómico) a las fundaciones y a las asociaciones declaradas de utilidad pública, aunque aquéllas carezcan de tal declaración, en la medida - cabría argumentar - en que su inscripción en el Registro de ONGDs implica un juicio positivo de la Administración acerca de que - a diferencia de otras asociaciones de interés particular - los fines perseguidos por éstas se encuentran relacionados con los principios y objetivos de la cooperación internacional para el desarrollo: son de interés general.

De lo anterior se desprendería, pues, que la inscripción en dicho Registro vendría ser el equivalente a la declaración de utilidad pública ${ }^{93}$; conclusión que se enfrentaría seguidamente al problema de

92 Recordemos que la definición de ONGD que ofrece el art. 32.1 de la Ley $23 / 1998$ se refiere a las que tengan entre sus fines o como objeto expreso la realización de actividades "relacionadas con los principios y objetivos» de la cooperación internacional para el desarrollo, que, tal cual son expuestos en dicha Ley, más allá de unos fines, incorporan una forma de entender la solidaridad con los países menos avanzados. Vid., especialmente, los arts. 2 y 3 de la Ley 23/1998, ya reproducidos anteriormente en las págs. 296 y ss.

93 Al margen de que ello pueda encontrar apoyo en el criterio sostenido por la propia Administración Tributaria (como luego veremos en el siguiente apartado al abordar la polémica sobre la necesidad de dicha declaración), respaldaría también tal pretensión el hecho de que el mismo proyecto de Reglamento del Registro de ONGDs de 2015 contemplara una serie de requisitos para la inscripción y mantenimiento de su efectividad que se aproximaban a los exigidos para la declaración de utilidad pública (aunque finalmente no todos prosperaran), así como la propia justificación esgrimida en su Exposición de Motivos ungiendo a dicho Registro como garante de la aplicación en su ámbito del régimen fiscal de las entidades sin fin de lucro (vid., supra, págs. 306 y ss.). A lo que cabría 
si, a pesar de la letra del art. 35 y del segundo inciso del art. 33.2, que no hacen distinción alguna, la necesidad de inscripción en dicho Registro como requisito para el disfrute del régimen de las entidades sin fin de lucro había de considerarse referida exclusivamente a las ONGDs no declaradas de utilidad pública, por cuanto que, respecto de las fundaciones y de las asociaciones que sí ostentan dicha calificación, aquel juicio sobre la naturaleza de sus fines ya aparece implícito en su inscripción en el Registro de fundaciones y en la declaración de su utilidad pública. Problema que nuevamente encuentra soluciones opuestas. Todo ello, sin olvidar su contraste con la Ley 49/2002, en cuya letra pretende encontrar sustento la primera de las exégesis anteriormente enunciadas.

\section{IV.A. Recapitulando}

En definitiva, a partir de lo expuesto, cabe realizar tres interpretaciones bien diferentes acerca de la indispensabilidad de la inscripción en el Registro de ONGDs como requisito para poder acceder al régimen tributario especial de las ESFL.

IV.A.1. Hipótesis 1: La irrelevancia en el régimen de la Ley 49/2002 de la ausencia de inscripción en el/los Registro/s de ONGDs

La primera de dichas interpretaciones consideraría que, a pesar de la letra y de las pretensiones del vigente Reglamento, la inscripción en el Registro de ONGDs en la actualidad no tiene - si es que llegó a tener- otros efectos distintos que los de proporcionar publicidad formal a las entidades dedicadas a la cooperación al desarrollo y, acaso, permitirlas el acceso a las referidas ayudas y subvenciones, pero sin que su falta de inscripción en el mismo les prive de los beneficios fiscales que puedan corresponderles en cuanto entidades sin fin de lucro; o, dicho en otros términos, que, a diferencia de

añadir - aunque esto no es más que una mera conjetura- la existencia de una probable concesión al sector más crítico de las ONGDs, que se habría traducido en procurar cierto alejamiento del Ministerio de Hacienda (cuyo informe, recuérdese, es preceptivo y vinculante en el procedimiento de declaración de utilidad pública) a favor de un mayor protagonismo del Ministerio de Asuntos Exteriores en la calificación de sus fines y, en particular, de la AECID, en cuanto encargada de dicho Registro, teóricamente más sensibilizada en la cooperación internacional al desarrollo. 
lo que, tal vez, cupiese interpretar bajo la vigencia de Ley 30/199494, hoy no se les «impone» - aunque nada se oponga y pueda resultarles ventajosa - una doble (e incluso triple) matriculación (a saber, en el Registro que les corresponda conforme a su naturaleza, en el Registro autonómico de ONGDs en el que puedan tener su sede y en el Registro de ONGDs de la AECID) para poder acceder a los beneficios del régimen de la Ley 49/2002 ${ }^{95}$; duplicidad que sólo bajo el criterio de la voluntariedad cabe razonablemente mantener. Y, a ese respecto, se hace difícil considerar que es verdaderamente "voluntario» un sistema que penaliza la no inscripción en dichos registros de ONGDs con la privación de beneficios fiscales en los tributos autonómicos y/o estatales e incluso con la pérdida de financiación derivada de la desincentivación de los donantes y mecenas como consecuencia del no reconocimiento del estatus fiscal de ESFL y, por ende, de su condición de "entidad beneficiaria del mecenazgo", a pesar de que la inscripción en el Registro de Fundaciones o en el de Asociaciones como asociaciones de utilidad pública conlleva un expreso pronunciamiento de la Administración no sólo de que carecen de fin de lucro - lo que es común a todas ellas-, sino acerca de cuáles son sus fines y que éstos son de interés general, que es la diferencia esencial que permite un trato fiscalmente dispar.

Así pues, conforme a esta primera exégesis, la Ley 49/2002 habría derogado el último inciso del art. 33.2. y el art. 35.1 de la Ley $23 / 1998^{96}$, en cuanto imponían la carga de matricularse en el Registro de ONGDs —además de inscribirse en el que proceda conforme a su naturaleza- como requisito para acceder al régimen fiscal de las entidades sin fin de lucro. En su lugar, la Ley 49/2002 sólo les exige su inscripción en «el registro correspondiente» (ya sea el estatal o el

94 Me refiero a partir del momento en que se aprobó la Ley 23/1998, en la medida en que el tenor literal de sus arts. 33.2 y 35.1 parecía condicionar para las ONGDs el disfrute de los beneficios recogidos en la Ley 30/1994 a que se encontrasen inscritas en el Registro de ONGDs.

95 Esa duplicidad (o triplicidad) se confirma, por citar un ejemplo, en el art. 2 del ya mencionado Decreto núm. 39/2009, de 6 marzo, por el que se regula el Registro Agentes de la Cooperación Internacional al Desarrollo de la Comunitat Valenciana, en cuyo apartado tercero dispone que "La inscripción en este registro es sin perjuicio de la inscripción en el Registro de Organizaciones No Gubernamentales de Desarrollo, adscrito a la Agencia Española de Cooperación Internacional para el Desarrollo y regulado por el Real Decreto 993/1999, de 11 de junio» (sustituido hoy por el Real Decreto 193/2015, como ya vimos), la cual, a su vez, se produce sin perjuicio de la inscripción en el registro que proceda conforme a su naturaleza jurídica [art. 7.d) del Reglamento del Registro de la AECID de 2015].

96 Sin que quepa invocar la DA $17^{\mathrm{a}}$ de la Ley 49/2002 como argumento en pro de su vigencia, ya que ello sólo cabría en lo que no se opongan a lo establecido a la Ley 49/2002; oposición que, sin embargo, se produce en lo que a este extremo se refiere. 
autonómico, pero en singular) ${ }^{97}$; el cual, en ausencia de aclaraciones por la propia Ley, parece lógico considerar que sería aquel que permita verificar o constituya un paso previo de la constatación de que se trata de entidades que carecen de fin de lucro y persiguen fines de interés general, facilitando el control y vigilancia de la Administración, por lo que, en principio, tal registro, por sus propias características, no podría ser otro que el que proceda de acuerdo con su naturaleza jurídica ${ }^{98}$. En este sentido, su matriculación en el Registro de ONGDs —en los «registros», en plural, porque, insisto, han de tenerse en cuenta también los autonómicos-, más que una obligación, constituiría un derecho de las ONGDs, sin perjuicio de que dicha inscripción siga siendo necesaria, pero fundamentalmente a los fines de obtener ayudas y subvenciones computables como ayuda oficial al desarrollo (AOD), que, conforme a esta interpretación, sería lo (único) que subsistiese del art. 33.2 de la Ley 23/199899, si es que dicho precepto, incluso desde antes, no hubiera de ser objeto de una interpretación correctiva ${ }^{100}$.

En todo caso, en lo que a la situación actual se refiere, adviértase que el legislador de la Ley 49/2002 pudo haber dicho, como, elocuentemente, sí dijo, por ejemplo, para las delegaciones de fundaciones extranjeras, que se considerarían entidades sin fines lucrativos: «c) Las ONGDs [inscritas en los registros] a que se refiere la Ley 23/1998, de 7 de julio, de Cooperación Internacional para el Desarrollo, siempre que tengan alguna de las formas jurídicas a que se refieren los párrafos anteriores». Pero no lo hizo. La omisión del inciso resaltado en negrita resulta igualmente reveladora si se contrasta esa ausencia con su expresa contemplación en el art. 35.1 de la Ley 23/1998. Por consiguiente, conforme a esta interpretación, cabría concluir que todas las ONGDs - y no sólo las inscritas en ese Registro- podrían gozar de los beneficios de la Ley 49/2002, siempre,

97 Art. $3.7^{\circ}$ Ley 49/2002.

98 No obstante, como enseguida veremos con más detalle en los siguientes subapartados, para aquellas ONGDs que no sean ni fundaciones ni asociaciones de utilidad pública — si se admite que quepan en el art. 2.c) de la Ley 49/2002_, el «registro correspondiente» a que se refiere su art. 3.7 sí cabría entender que es el Registro/s de ONGDs. Otra cosa, como apuntaba, será si dicho tipo de ONGDs caben en la letra del art. 2.c) o, por el contrario, el hecho de no estar declaradas de utilidad pública las inhabilita de entrada para poder ser consideradas entidades sin fin de lucro, caso en que, obviamente, ya no habría lugar a interrogarnos acerca de cuál es para ellas el «registro correspondiente», ni si cumplen o no los restantes requisitos, que es justamente el criterio de la hipótesis que ahora estamos viendo.

99 A pesar del criterio contrario del art. 10 del Reglamento del Registro de la AECID de 2015, que lo reputa vigente.

100 Vid. infra, pág. 344 y ss. 
claro es, que cumplan los requisitos formales y materiales exigidos y se acojan al régimen fiscal establecido en la misma.

A este respecto es importante subrayar que la Ley 23/1998 no subordina la consideración de ONGD a su inscripción en el (los) Registro(s) de ONGDs. El art. 32 dispone que se considerarán ONGDs las que cumplan los requisitos que dicho precepto establece y luego, en su art. 33, dice que éstas "podrán» inscribirse en el Registro de la AECID (o en el autonómico que proceda). Repárese, pues, en que lo que se condiciona a dicha inscripción no es su consideración como ONGD, sino el disfrute de determinadas medidas de fomento. De ahí resultaría, por ejemplo, que una fundación dedicada a la cooperación al desarrollo sea una ONGD, esté inscrita o no en dicho Registro. Otra cosa es que, sin esa inscripción, no pueda ser objeto de ayudas o subvenciones computables como AOD, pero nótese que esa falta de inscripción tampoco impediría que pudieran ser beneficiarias de otras ayudas o subvenciones distintas ${ }^{101}$.

101 Originariamente, el Proyecto de Ley de Cooperación Internacional para el Desarrollo remitido por el Gobierno (Proyecto de Ley núm. 121/000077) sí establecía la obligatoriedad de la inscripción en dicho Registro (cfr. art. 29.1 del citado Proyecto), aunque no quedaba del todo claro si era un requisito para ser consideradas ONGDs o para disfrutar de las ayudas, subvenciones e incentivos fiscales a que se refería. En todo caso, durante la tramitación parlamentaria se admitieron diversas enmiendas, en particular, la formulada en el Congreso por el Grupo Parlamentario Catalán (enmienda núm. 342), en el sentido de «incorporar el carácter potestativo de la inscripción» en el RONGDs, según literalmente se hacía constar en su justificación. La enmienda núm. 187, formulada por el Grupo Socialista, formalmente rechazada, incluía también ese carácter potestativo, aunque cabría estimar que ello se predicaba más bien en relación al ámbito del Registro estatal, esto es, habida cuenta de la posibilidad de inscribirse en los que pudieran crear las CCAA. No obstante, en la enmienda núm. 188 de dicho mismo Grupo se postulaba que las ONGDs «deberán inscribirse en el mencionado Registro al objeto de poder participar en las correspondientes convocatorias»; es decir, no para ser consideradas como ONGDs, sino como requisito para disfrutar de las ayudas y subvenciones de la Administración General del Estado en el campo de cooperación para el desarrollo (vid., BOCG, VI Legislatura, serie A, núms. 81-07, de 17 de noviembre de 1997). Paradójicamente, en la enmienda núm. 115 presentada por dicho mismo partido en el Senado, entre otras modificaciones, proponía que dicho precepto dijera "se inscribirán» —en vez de "podrán inscribirse», como decía el texto aprobado en el Congreso-, a pesar de que dicho precepto ya hacía referencia a que su inscripción en los correspondientes registros de ONGDs era "condición indispensable» para recibir de las Administraciones Públicas, en el ámbito de sus respectivas competencias, ayudas o subvenciones computables como Ayuda Oficial al Desarrollo, así como para disfrutar de los beneficios fiscales que mencionaba en su art. 35 (Cfr. BOCG, Senado, VI Legislatura, serie II, núm. 84(c), de 27 de mayo de 1998, p. 48). En cualquier caso, con la aceptación de la referida enmienda núm. 342 del GC (CiU) quedaría aclarado ese carácter potestativo que se recogería en el Dictamen de la Comisión (BOCG, VI Legislatura, serie A, núm. 81-12, de 22 abril 1998, pp. 204-205), aprobándose por el Pleno del Congreso - ya como artículo 33- 
En definitiva, podemos resumir en dos los puntos clave de esta interpretación: 1) se pliega sin esfuerzo a la letra del art. 2.c) de la Ley 49/2002, que no exige su inscripción en el Registro de ONGDs, identificando el «registro correspondiente» del art. 7.3 con el que proceda de acuerdo con su naturaleza jurídica, en cuanto que éste permite o es paso previo para verificar que se trata de entidades que carecen de fin de lucro y persiguen fines de interés general, facilitando el control y vigilancia de la Administración, lo que no es el caso del RONGDs, que resulta insuficiente para dicho propósito; y, 2) impide la discriminación entre entidades sin fin de lucro (v.gr., entre ONGDs y ONGs de Acción Social) y la mayor onerosidad de dedicarse a unos fines de interés general que a otros, cuando dicha Ley no distingue, evitando las nocivas consecuencias de una obligatoria duplicidad de inscripciones en diferentes Registros para poder acceder al repetido régimen fiscal; régimen al que, en principio, debieran poder optar desde su inscripción en el de Fundaciones o desde su declaración de utilidad pública, en el caso de las asociaciones, dado que es en ese preciso momento cuando ya se han valorado aspectos basilares como sus fines y actividades.

No obstante, esta interpretación se enfrenta aún a algunos problemas (lamentablemente, ninguna de las que cabe vislumbrar los orilla por entero). El principal, que el Reglamento del Registro de ONGDs de 2015 sostiene la vigencia actual de los arts. 33.2 y 35 de la Ley $23 / 1998^{102}$, vinculando el disfrute de los beneficios del régimen de las entidades sin fin de lucro a su inscripción en dicho Registro.

IV.A.2. Hipótesis 2: La inscripción en el/los Registro/s de ONGDs como conditio sine qua non para el disfrute del régimen fiscal de la Ley 49/2002 sólo para las que sean asociaciones no declaradas de utilidad pública

La exégesis de que ahora me ocuparé sortea algunos de los obstáculos que se oponen a la anterior, aunque es susceptible también de algunas objeciones. Veamos.

y sin modificaciones en el Senado, consagrándose definitivamente en la Ley (vid., BOCG, VI Legislatura, serie A, núms. 81-14 y 81-15, de 22 abril y 22 de junio de 1998 , pp. 219 y 243 , respectivamente).

102 Vigencia que, ya antes de dicho Reglamento, había sido también defendida por un importante sector de la doctrina: así, CRUZ AMORós, M. y LÓPEz RiBAS, S.: La fiscalidad en las entidades sin ánimo de lucro: estímulo público y acción privada. Cideal-PriceWaterhouseCoopers, Madrid, 2004, pág. 16). 
Básicamente, esta interpretación, a diferencia de la anterior, sí admitiría la obligatoriedad de la inscripción en el Registro/s de ONGDs como requisito o condición indispensable para el disfrute del repetido régimen fiscal, pero sólo respecto de aquéllas que, teniendo la forma de asociación, no estuvieren declaradas de utilidad pública, obviando así la crítica que se formulaba desde la interpretación anterior a causa, entre otros motivos, de la discriminación y onerosidad que representaba la duplicidad a que, en otro caso, se sometería a las ONGDs que fueran fundaciones o asociaciones de utilidad pública.

Por otra parte, esta hipótesis resultaría defendible tanto en el caso de que se considere, al igual que en la anterior, que el último inciso del art. 33.2. y el art. 35 de la Ley 23/1998 han quedado derogados por la Ley 49/2002 (supuesto en que la exigencia de estar inscritas en el Registro de ONGDs derivaría para estas asociaciones del propio art. 3.7 de la Ley 49/2002: para ellas sería el «registro correspondiente», puesto que la mera inscripción en el Registro de Asociaciones no serviría para dilucidar si sus fines son de interés general), como en el caso de que, distintamente, se entendiese que dichos preceptos de la Ley 23/1998 siguen en vigor, pero considerando que su significado era más limitado que el que, a priori, parece resultar de su tenor literal, de manera que queda contraído a aquellas ONGDs que no sean ni fundaciones ni asociaciones de utilidad pública.

En efecto, conforme a esta segunda lectura, cabría interpretar, incluso originariamente, que cuando el repetido art. 33.2 establece que la inscripción en alguno de los registros de ONGDs —el de la AECID o los autonómicos- «será también necesaria para que las organizaciones no gubernamentales de desarrollo puedan acceder a los incentivos fiscales a que se refiere el artículo 35», aquel precepto había de leerse en el sentido de que «Dicha inscripción será también necesaria para que las organizaciones no gubernamentales de desarrollo [distintas de las que ya disfrutan o puedan disfrutar del régimen fiscal de las $E S F L^{103}$ ] puedan acceder a los incentivos fiscales a que se refiere el artículo 35»104; esto es, el precepto se estaría refiriendo implícitamente a las asociaciones no declaradas de utilidad pública, pero cuyos fines estatutarios fueran de interés general y consistie-

103 Id est, distintas de las que ya se ha comprobado por la propia Administración que sus fines son de interés general, como es el caso de las fundaciones y de las asociaciones declaradas de utilidad pública.

104 Nótese, cabría añadir siguiendo esta línea discursiva, que si fueran exactamente las mismas que ya disfrutan o pueden disfrutar del régimen fiscal de las ESFL, ni el referido art. $33.2 \mathrm{ni}$ el art. 35.1 tendrían mucho sentido. 
ran justamente en la realización de actividades relacionadas con los principios y objetivos de la cooperación internacional para el desarrollo, de manera que ello pudiera serles reconocido por la Administración - por la AECID - a través de su inclusión en el Registro de ONGDs. En otras palabras, conforme a esta interpretación, el propósito de dicho artículo habría sido el de permitir el disfrute de dicho régimen fiscal a las que, antes de la referida Ley 23/1998, no podían acogerse al mismo (por falta de dicha declaración y sin perjuicio de cumplir los demás requisitos de forma y fondo), pero no la de suprimir los beneficios propios del mismo a las ONGDs que ya gozaban de ellos, aunque no se hubieren inscrito en el Registro de la AECID (o, en su caso, en el autonómico que procediese).

Lamentablemente, la técnica legislativa $-\mathrm{o}$, más bien, su ausencia- resulta de todo punto censurable y, como antes avanzaba, la interpretación anteriormente expuesta tampoco resulta concluyente: cabe estimar, distintamente, que, para el caso de las entidades que tengan como fin la cooperación para el desarrollo, dicho registro ha de ser, en todo caso, el Registro de ONGDs (el de la AECID o los que con idéntica finalidad puedan haber creado las $\mathrm{CCAA}^{105}$ ), con independencia de que puedan o deban estarlo también en otros Registros según su naturaleza jurídica.

Esta última interpretación, como a continuación explicaré con más detalle, es de la que parece partir el vigente Reglamento del Registro de ONGDs, basándose en la literalidad de los arts. 33 y 35 de la Ley 23/1998 106 , y la que parece aceptar también un importante sector de la doctrina ${ }^{107}$.

105 Si se acepta, respecto de esta otra dicotomía, la exégesis más conforme con la literalidad de la Ley. Recuérdese, conforme vimos más atrás, que la dicción literal del Reglamento de 2015 da pie a considerar que es la inscripción en el Registro de la AECID, y no la que pueda efectuarse en los registros autonómicos, la que se exige para poder acceder a régimen de la Ley 49/2002. Con arreglo a dicha lectura, la inscripción en aquéllos sólo es funcional respecto de las ayudas y subvenciones acordadas por la respectiva Comunidad Autónoma o respecto de los beneficios fiscales que ésta haya podido establecer en sus tributos. Vid supra pág. 312.

106 Vid. Exposición de Motivos, pfos. $2^{\circ}$ y $3^{\circ}$, y art. 10, último inciso.

107 Por todos, GIL DEL CAMPO, M.: Fiscalidad de fundaciones, asociaciones y del mecenazgo, CISS, Valencia, 2003, pág. 112; y, posteriormente, el mismo autor, en Contabilidad y Fiscalidad de las entidades sin fines lucrativos y del mecenazgo, CISS, Madrid, 2010, pág. 144. Véase, asimismo, Blázouez Lidoy, A. y Martín DÉGano, I.: Manual tributario de entidades no lucrativas (asociaciones y fundaciones). Centro de Estudios Financieros, Madrid, 2012, pág. 29. 


\section{IV.A.3. Hipótesis 3: El Registro de ONGDs como el «registro correspondiente» del art. 3.7 de la Ley 49/2002}

Así es. Si admitimos la hipótesis de que las ONGD, a efectos del régimen de la Ley 49/2002, constituyen una categoría independiente de las fundaciones y asociaciones (siquiera sea por la distinción que el propio legislador efectúa en dicha ley en mérito de la especificidad de sus fines), cabría considerar que, sin perjuicio de que deban inscribirse, a los efectos constitutivos o informativos que procedan, en el Registro de Fundaciones o Asociaciones, dichas ONGDs, en la medida en que pretendan su reconocimiento como ESFL al solo amparo del art. 2.c) de la Ley 49/2002 (v.gr., porque tengan como único fin la cooperación para el desarrollo), deben inscribirse también necesariamente en el Registro de ONGDs como «condición indispensable» tanto para recibir ayudas o subvenciones computables como ayuda oficial al desarrollo como para poder acceder a los incentivos fiscales del régimen de la Ley 49/2002. Y ello, no sólo porque así resultaría de una lectura literal del art. 33.2 de la Ley 23/1998 en relación con el art. 35 de la misma Ley y la DA $17^{\text {a }}$ de la Ley 49/2002, sino también porque, siguiendo esta hipótesis, el registro "correspondiente» a que se estaría refiriendo el apartado 7 del art. $3^{\circ}$ de la Ley 49/2002 no podría ser sino el específicamente previsto para las entidades que en cada caso se trate - y de las que ahora se trata es de las del art. 2.c), esto es, de las ONGDs-, sin perjuicio, se ha de insistir, de que puedan o deban estarlo en otros registros por razón de su naturaleza. Adviértase, cabría argumentar, que, en otro caso, tanto el art. 2.c) de la Ley 49/2002 como el art. 33.2 de la Ley 23/1998, carecerían de efectividad real alguna, resultarían completamente irrelevantes, írritos (conclusión, permítaseme decirlo, que, dada la defectuosa técnica de dichas leyes, tampoco puede descartarse en absoluto).

Además, cabría oponer a la tesis anterior que la supuesta intención del Legislador de no perjudicar a las ONGDs no inscritas que eventualmente gozaran de la consideración de ESFL carece de soporte alguno: no hay evidencias, sino antes al contrario, de que el propósito del Legislador no fuera obligar a todas las organizaciones que actúan en el ámbito de la cooperación al desarrollo, cualesquiera que fuese su forma o calificación, a inscribirse en el Registro de ONGDs si querían seguir disfrutando tanto de la AOD como de los beneficios fiscales que les correspondieran como entidades sin fin de lucro, siquiera fuese como fórmula que coadyuvase a la finalidad de disponer de un censo actualizado de las organizaciones de la sociedad civil comprometidas dicho ámbito; a saber, de un Regis- 
tro de ONGDs como el que, a la sazón, creaba la Ley 23/1998 justamente en el apartado anterior de dicho mismo art. 33.2.

Ahora bien, si se estima, con arreglo a esta última exégesis, que, en sintonía con los arts. 33.2 y 35 de la Ley 23/1998 y el art. 10 del Reglamento del RONGDs, el «registro correspondiente» en el caso de las entidades que tengan como fin la cooperación al desarrollo es el Registro de ONGDs, habrá de aceptarse que una fundación instituida con tales fines e inscrita en el Registro de Fundaciones (como es necesario que lo esté para que ostente personalidad jurídica) no podría gozar del régimen de la Ley 49/2002 si no está inscrita también en el correspondiente Registro de ONGDs, puesto que, como se ha dicho, incumpliría el requisito del art. $3.7^{\circ}$ de dicha Ley («que estén inscritas en el registro correspondiente») en conexión con el citado art. 33.2 y concordantes. Otra cosa sería que se tratase de una fundación (o de una asociación de utilidad pública) que tuviere fines múltiples, entre los que se encontrasen, además de la cooperación al desarrollo, otros distintos y que fuera en mérito de estos últimos por los que se pretendiera su reconocimiento como ESFL. En cambio, una asociación no declarada de utilidad pública, pero que estuviere inscrita en el/los Registro/s de ONGDs, en principio, sí podría acogerse a dicho régimen fiscal ${ }^{108}$. Otro debate es el de si el requisito de la «forma jurídica» a que se refiere el art. 2.c) de la Ley 49/2002 implica o no la necesidad de que ostente la calificación de utilidad pública; asunto que será objeto de análisis en el siguiente apartado.

Pero, en suma, en lo que concierne la cuestión que ahora nos ocupa, por las razones que he venido exponiendo, la solución no resulta clara y, desde luego, no cabe rechazar la posibilidad de que una fundación o una asociación de utilidad pública que tengan como finalidad principal —e incluso única- la realización de «actividades "relacionadas" con los principios y objetivos de la cooperación internacional para el desarrollo» puedan disfrutar del régimen de la Ley 49/2002, aunque no se hayan inscrito en el Registro de ONGD, desde el momento en que se interprete que, a pesar de caber en el concepto de ONGD (i.e., a pesar de tratarse de ONGDs con arreglo al concepto contenido en el art. 32 de la Ley 23/1998), pueden ampararse - como si no lo fueran- en las letras a) o b) del referido art. 2, en cuyo caso

108 Permítaseme anotar a este respecto, en línea con lo que más atrás expuse, que justamente evitar la posibilidad de que la inscripción en un Registro autonómico pudiera surtir un efecto equivalente a la declaración de utilidad pública, habida cuenta de los términos de la Ley 23/1998, constituiría una de las razones que se encuentran detrás del Reglamento del Registro de ONGDs de la AECID. Vid., supra, apdos. III.B y III.C. 
el «registro correspondiente» sería el propio de su naturaleza jurídica: el registro de asociaciones o el fundaciones, estatal o autonómico, según proceda. En este sentido, cabría razonar que, aunque se dediquen a la cooperación para el desarrollo, no por ello dejan de ser fundaciones o asociaciones de utilidad pública.

Ahora bien, adviértase, entonces, cómo de esta guisa llegaríamos a una solución coincidente, en la práctica, con la segunda de las interpretaciones expuestas; a saber, que no obstante a la dicción literal de los arts. 33.2 y 35 de la repetida Ley 23/1998, la inscripción en el RONGDs, verdaderamente, solo se impone como condición indispensable para disfrutar de los beneficios de la Ley 49/2002 respecto de aquellas ONGDs que sean asociaciones no declaradas de utilidad pública.

\section{LA (CONTROVERTIDA) NECESIDAD DE LA DECLARACIÓN DE UTILIDAD PÚBLICA COMO REQUISITO PARA DISFRUTAR COMO ONGDS DEL RÉGIMEN DE LA LEY 49/2002.}

Como se ha venido exponiendo en anteriores apartados, el concepto de ONGD acogido por la Ley 23/1998 — que, frente a otras eventuales concreciones, es, como se dijo, a la que se remite específicamente la Ley 49/2002-, es un concepto relativamente amplio en el que, prescindiendo de la forma jurídica que puedan haber adoptado, prima el criterio teleológico, tanto en sentido negativo, para excluir aquellas que persigan fines lucrativos, como positivo, para comprender las que estatutariamente tengan como finalidad la realización de actividades relacionadas con los principios y objetivos de la cooperación para el desarrollo ${ }^{109}$.

Ahora bien, aun a riesgo de ser reiterativo, convendrá recordar que esa relativa amplitud no supone que todas las ONGDs vayan a ser objeto del tratamiento favorable que se contiene en el régimen fiscal de las ESFL. Ni siquiera van a serlo todas las que se encuentren inscritas en el/los Registro/s de ONGDs. La Ley 49/2002, otorgándoles, eso sí, una mayor visibilidad en comparación con su predecesora -lo que, a tenor de alguna de las interpretaciones que antes expuse, sería, probablemente, el principal, por no decir único, propósito de su art. 2.c)—, se refiere notoriamente a ellas en dicho precepto singularizándolas como uno de los tipos de entidad susceptibles de disfrutar del repetido régimen especial, pero su consideración como entidades sin fin de lucro - y reténgase bien ese extremo: como entidades sin fin

109 Vid, supra, apdo. II. 
de lucro, no como entidades equiparadas ${ }^{110}$ - , se subordina inmediatamente, además de al cumplimiento del decálogo que especifica en su artículo 3, a que tengan "alguna de las 'formas jurídicas' a que se refieren los párrafos anteriores» (relativos, como sabemos, a las fundaciones y a las asociaciones declaradas de utilidad pública).

Es, justamente, esa desafortunada expresión, como ya anticipé al inicio de este trabajo, la que provocará la polémica —o, más bien, la que la reabre, porque, como dije, ésta es herencia directa de la Ley 23/1998 - En efecto, salvando a las fundaciones, en que la referencia a las formas jurídicas no ofrece especial dificultad, en el caso de las asociaciones la expresión plantea un serio problema interpretativo con importantes consecuencias, pues tanto las declaradas como las no declaradas de utilidad pública pertenecen al mismo tipo de persona jurídica, «revisten la misma forma»: son asociaciones. Lo que, en suma, nos sitúa ante una difícil encrucijada en orden a las exigencias para la aplicación de este régimen fiscal: a saber, la suficiencia de la forma jurídica asociativa cuando se encuentren inscritas en el correspondiente registro de ONGDs $v s$. la necesidad de que, además (o solamente: otro punto del debate), se encuentren declaradas de utilidad pública.

Para desbrozar el camino hacia el desenlace de esa disyuntiva, resulta conveniente comenzar recordando algunos hitos.

I. Bajo la vigencia de la Ley 30/1994 y hasta la entrada en vigor de la Ley 23/1998, las ONGDs, aunque no se mostrasen especialmente "subrayadas», como hoy se encuentran merced a su expresa contemplación en el art. 2.c) de la Ley 49/2002, era incuestionable que podían disfrutar del régimen especial de las ESFL, entronizado entonces por la Ley 30/1994 —recuérdese, de nuevo, que su art. 42.1.a) ya contemplaba la "cooperación para el desarrollo» como uno de los fines de interés general de las entidades sin fin de lucro-, pero, recordémoslo también, ello era así solo en tanto se tratase de fundaciones o de asociaciones declaradas de utilidad pública (art. 41), entre cuyos fines la misma Ley 30/1994 había hecho expresa mención de la "cooperación para el desarrollo», tanto por lo que se refiere a las fundaciones (art. 2.1), como por lo que concierne a las asociaciones declaradas de utilidad pública, respecto de las que su disp. adicional $13^{\mathrm{a}}$ había dado nueva redacción al art. 4 de la Ley de Asociaciones de $1964^{111}$ (entonces todavía vigente) para reflejar, explícitamente, que éstos se encontraban entre los fines de interés ge-

110 Vid. infra pág. 353. La cuestión, por otra parte, ya fue anticipada más arriba: vid. supra nota 85 , pfos. tercero y último, y también pág. 335 y ss.

111 Me refiero a la Ley 191/1964, de 24 de diciembre (BOE núm. 311, de 28 de diciembre de 1964). 
neral que habían de perseguir inexcusablemente para obtener dicha declaración ${ }^{112}$.

Así pues, se compartiera o no la restricción, lo cierto es que resultaba pacífico y no planteaba incertidumbre alguna que las asociaciones que tuviesen como fin la realización de actividades relacionadas con la cooperación internacional para el desarrollo solamente se consideraban entidades sin fin de lucro en el caso de que estuvieran declaradas de utilidad pública y cumplieran los requisitos establecidos en el Título II de la Ley 30/1994.

II. El conflicto cuando se origina es a partir de la Ley 23/1998. Como ya expliqué al comienzo, su art. 35.1 afirmaba que la aplicación del régimen fiscal de las entidades sin fin de lucro quedaba restringida, exclusivamente, a aquellas ONGDs que revistieran la misma forma jurídica y cumplieran los mismos requisitos que las demás ESFL, o dicho en otros términos, parecía consagrar el criterio de que sólo en la medida en que las ONGDs se acomodasen plenamente al concepto de ESFL, establecido entonces por la Ley 30/1994, podrían disfrutar de dicho régimen especial. A primera vista, parecía, pues, que en este aspecto la Ley 23/1998 más que crear Derecho lo recreaba, puesto que se limitaba a extraer una conclusión que ya resultaba de la propia Ley 30/1994.

Ahora bien, como vimos en el apartado anterior, tanto este artículo 35.1 como el último inciso del art. 33.2, establecían un requisito adicional respecto de la situación precedente: imponían, como «condición indispensable» para disfrutar de los incentivos fiscales que compendiaba en su art. 35, la inscripción en el Registro de la AECID o en los que con idéntica finalidad pudieran crearse por las CCAA. Tal exigencia, unida a la alusión a la "forma jurídica», sin más aclaraciones, terminarían engendrando incertidumbre y abonando la idea de que también las asociaciones no declaradas de utilidad pública - siempre que estuvieren inscritas en el correspondiente registro de ONGDs- podrían beneficiarse de la aplicación del régimen fiscal de las entidades sin fin de lucro.

112 Originariamente, el art. 4.1 de la Ley de Asociaciones de 1964 establecía que «Las Asociaciones dedicadas a fines asistenciales, educativos, culturales, deportivos $O$ cualesquiera otros fines que tiendan a promover el bien común, podrán ser reconocidas como de «utilidad pública». Hoy, la referencia habría de entenderse realizada al art. 32.1.a) de la LODA, donde se enumeran de forma más amplia, aunque tampoco exhaustiva, los distintos fines estatutarios tendentes a promover el interés general, entre los que se encuentran expresamente mencionados los correspondientes a la cooperación para el desarrollo, añadidos por la citada DA $13^{\text {a }}$ de la Ley 30/1994 a la anterior Ley de Asociaciones de 1964, como se indica en el texto. 
Y verdaderamente, al menos hasta la entrada en vigor de la Ley 49/2002, no faltaban argumentos para sostener dicha conclusión.

En efecto, si se examina el citado art. 35.1 más detenidamente, sin dejarnos llevar por la inercia que podría representar su lectura a la sola luz de la Ley 30/1994, podremos observar sin esfuerzo que la aplicación del régimen fiscal de las entidades sin fin de lucro no es sino el «resultado». El presupuesto que lleva al Legislador de la Ley 23/1998 a establecer esa consecuencia jurídica se presenta, sin embargo, más difícil de determinar pacíficamente y con precisión.

Por un lado, cabría interpretar que - aun de forma ciertamente redundante - así lo dispuso la citada Ley porque, guiada, como más atrás se apuntó, por cierto afán omnicomprensivo y el deseo de noticiar el fomento de la cooperación para el desarrollo llevada a cabo por los agentes sociales y, particularmente, por las ONGDs, pretendió explicitar en dicho precepto el corolario - ya deducible de la legislación fiscal entonces vigente- de que, en tanto que las ONGDs revistiesen la forma jurídica y cumpliesen los requisitos establecidos en la Ley 30/1994, «eran» entidades sin fin de lucro y, puesto que lo eran, les resultaba aplicable dicho régimen.

Desde el lado contrario, en cambio, cabría razonar que el Legislador de la Ley 23/1998 partía de postulados diametralmente opuestos a los que presume la anterior tesis; a saber, consideraría que la Ley 23/1998 habría alterado el régimen de la Ley 30/1994 en relación a las ONGDs, estimando que pese a no ser éstas entidades sin fin de lucro (y al igual que acaece con otras entidades a quienes, sin ser reconducibles a dicha categoría, la Ley 30/1994 les concede, no obstante, la aplicación de este régimen $)^{113}$, i.e., que a pesar de que las ONGDs, tal como eran concebidas en la Ley 23/1998, no quedaban reducidas a las fundaciones y asociaciones de utilidad pública como sucedía con las ESFL, merecían, no obstante, poder aplicar idéntico régimen fiscal que si lo fueran, siempre, eso sí, que, además de los requisitos formales y materiales establecidos en la Ley 30/1994 (id est, tratarse de fundaciones o asociaciones — sin más - y reunir los requisitos establecidos en el Título II de la citada Ley), cumplieran adicionalmente una condición homologadora: la constatación por la Administración competente de que sus fines consistían en la realización de actividades relacionadas con los principios y objetivos de la cooperación internacional para el desarrollo» y que, por consiguiente,

113 Recuérdese lo expuesto supra, nota 85, párrafos tercero y último, a propósito del art. 35.4 de la Ley 23/1998 en relación a las disposiciones adicionales de la Ley 30/1994 y en particular de su DA 6 . 
eran de interés general, por lo que no procedía dispensarlas un trato fiscal menos beneficioso, como si se tratase de meras asociaciones de interés particular. Por explicarlo plásticamente, el Legislador de la Ley 23/1998, según esta tesis, debió considerar que una ONGD, aunque no se encuentre declarada de utilidad pública, no es un club gastronómico de amigos o un círculo de recreo ${ }^{114}$. Y aunque, como asociaciones, todas ellas carezcan de ánimo de lucro ${ }^{115}$, los fines de una ONGD, a diferencia de aquéllas, siempre e inexcusablemente son - deben ser- de interés general para que puedan ser consideradas como tales; constatación que se produciría merced a su inscripción en el Registro de ONGDs ${ }^{116}$.

En definitiva, como ya se hizo notar más atrás ${ }^{117}$, el problema residía en dilucidar si la Ley 23/1998 confirmaba la Ley 30/1994 en punto a los casos y requisitos en que las ONGDs eran consideradas ESFL y, en consecuencia, podía aplicárseles el régimen fiscal especial propio de las mismas, o si, distintamente, dicha Ley sustrajo a las ONGDs del ámbito de la Ley 30/1994 para considerarlas no entidades sin fin de lucro (que es el tratamiento y calificación que recibían hasta ese momento cuando tenían la forma y se plegaban a los requisitos a que se refería el art. 41 de dicha última Ley), sino para concebirlas como una categoría independiente, sin perjuicio de que luego las atribuyese el régimen fiscal que correspondía a aquéllas, pero reformulando las condiciones; id est, sustituyendo, en el caso

114 En este sentido, entre otros ejemplos que, a su juicio, no podían considerarse sino de puro interés privado, citaba ALBALADEJO los de aquellas asociaciones cuyo objeto fuera «el de satisfacer necesidades económicas no lucrativas, o bien puramente ideales (así, de recreo), pero atinentes sólo a los componentes (miembros) de la entidad, y no útiles para la comunidad (por ejemplo, una docena de amigos forman una asociación cerrada al ingreso de nuevos miembros, a la que aportan bienes, con el exclusivo objeto de divertirse y viajar)». Cfr., AlBALADEJO, M.: Derecho Civil, tomo I, vol. 1 ${ }^{\circ}$ Librería Bosch, Barcelona, 1980, pág. 387.

115 Exposición de Motivos, apdo. II y arts. 1.2, 7.1.k) y 13.2 de la LODA.

116 No siendo ocioso añadir - porque da noticia de que ya la idea inicial parecía discurrir en esa dirección- que originariamente, en el Proyecto de Ley, dicha inscripción era, por un lado, obligatoria con carácter general (esto es, no sólo para el acceso a una específica financiación pública o para la obtención de ventajas fiscales); y, por otro, que su indispensabilidad para poder recibir ayudas o subvenciones computables como ayuda oficial al desarrollo, o para acceder a los incentivos fiscales que detallaba en su texto, se predicaba respecto de la inscripción en el Registro de la AECID, exclusivamente; aspectos que se modificarían durante su tramitación parlamentaria para igualar el Registro estatal y los autonómicos y para establecer la voluntariedad de la inscripción, sin perjuicio de su exigencia para hacerse acreedoras de la ayuda al desarrollo y las ventajas fiscales que señalaba. Vid. infra notas 119 y 120

117 Vid. supra nota 85, pfos. tercero y último, y también pág. 335 y ss. 
de las asociaciones, la declaración de utilidad pública por su inscripción en el correspondiente Registro de ONGDs, aunque imponiendo también a las restantes la misma disciplina.

Ciertamente, esta última es la impresión que, prima facie, se desprendería de la tramitación parlamentaria de la Ley 23/1998. Permítaseme reproducir, porque resultan bien elocuentes a este respecto, las palabras del diputado del Grupo Parlamentario Catalán CiU, Sr. Recoder i Miralles, durante la sesión plenaria del debate sobre el dictamen de la Comisión al proyecto de ley, cuyas enmiendas, debo señalar, tuvieron una importancia decisiva en la redacción final del art. 35 de dicha Ley (art. 31 en el Proyecto) ${ }^{118}$, a las que habrían de sumarse las formuladas por el Grupo Parlamentario Vasco en relación a los arts. 33 y 35.6 (arts. 29 y 31 del Proyecto) ${ }^{119}$. Diría así en su intervención el citado representante de CiU:

«En primer lugar, quiero reivindicar la paternidad de las tres enmiendas de este grupo parlamentario al artículo 31 que sitúan el régimen fiscal de las ONG, a partir de la aprobación de esta ley, entre los mejores regímenes fiscales que hoy existen en nuestro ordenamiento para cualquier tipo de asociación. Las ONG, por el solo hecho de inscribirse en los registros que crea la ley (en el del Estado - de la AECI - o en los que se creen en el seno de las comunidades autónomas, que van a producir exactamente los mismos efectos), van a tener la consideración y el tratamiento de entidades de utilidad pública» ${ }^{120}$.

Evidentemente, con ello no podemos tener por zanjada la cuestión. Es menester recordar que no es la intención de un imaginario legislador -la voluntas legislatoris-, sino la voluntas legis la que

118 Me refiero a las enmiendas núms. 345, 346 y 347, a las que alude en su intervención el representante del Grupo Parlamentario CiU y que ya tuve oportunidad de comentar más atrás: vid., notas 83 y 85; así como también a la enmienda núm. 342, relativa al art. 29.1 del Proyecto (art. 33.1 de la Ley), por la que se daría carácter potestativo de la inscripción en el Registro de la AECID: vid. nota 102. Todas ellas aceptadas, según luce en el Informe de la Ponencia: cfr. BOCG, VI Legislatura, serie A, núm. 81-10, de 30 de marzo de 1998, págs.175-176.

119 Así, la enmienda núm. 69, de modificación del art. 29.1 del Proyecto (art. 33.1 de la Ley), merced a la cual se desterraba cualquier atisbo de que el Registro de la AECID fuera el único constitutivo y excluyente para que las ONGDs pudieran acceder a fondos de cualquier Administración Pública; la enmienda núm. 70, de modificación del art. 29.2 del Proyecto (art. 33.2 de la Ley), mediante la que se parificaba el Registro estatal y los autonómicos; y la enmienda núm. 71 (ya comentada más atrás: vid., nota 86), por la que se garantizaban de modo expreso las competencias autonómicas para establecer sus propios incentivos fiscales. Cfr. BOCG, VI Legislatura, serie A, núm. 81-7, de 17 de noviembre de 1997, pág. 73.

120 Diario de Sesiones del Congresos de los Diputados, VI Legislatura, año 1998, núm. 153, Sesión Plenaria núm. 148, de 23 de abril de 1998, pág. 8167. La negrita es mía. 
nos interesa desentrañar ${ }^{121}$. Máxime, si tenemos en cuenta que esa pretendida voluntad del legislador no se muestra de forma clara e incontestable, como revela el hecho de que fuese rechazada la enmienda núm. 190 del Grupo Parlamentario Socialista encaminada, precisamente, a establecer que el régimen fiscal de las entidades sin fin de lucro fuese directamente aplicable a las ONGDs inscritas que cumplieran los requisitos que a dichos efectos se estableciese en la regulación del Registro de ONGDs que creaba la Ley 23/1998. Rechazo que, desde luego, resulta difícil de conciliar con la interpretación del representante de $\mathrm{CiU}$ a que antes nos referíamos ${ }^{122}$.

Abunda también en ello, como veremos, la tramitación de la posterior Ley 49/2002 en la que, de otras intervenciones parlamentarias, se deduciría que el Grupo entonces mayoritario - que lo había sido también en la VI Legislatura en que se aprobó la Ley 23/1998- no compartía la interpretación que en su momento había efectuado CiU sobre el alcance del art. 35 de la Ley 23/1998, el cual, antes al contrario, sería explicado en un sentido continuista de la Ley 30/1994, demandando como esencial la declaración de utilidad pública, en el caso de las asociaciones, para que éstas pudieran optar por el régimen fiscal de las entidades sin fin de lucro ${ }^{123}$.

121 Adviértase, como señalaba DIEZ-PICAZO, que, «en ordenamientos complejos como los contemporáneos —especialmente si están inspirados en el principio democrático-, no existe una sola persona usualmente identificable como autor de la norma, sino que en la producción normativa concurre una pluralidad de personas, con voluntades no necesariamente coincidentes», a lo que, entre otros argumentos, añadía dicho autor que un tal tipo de exégesis "cierra el paso a cualquier posible nueva interpretación extensiva o evolutiva y resulta, por ello, tendencialmente incompatible con otros criterios interpretativos», denunciando que bajo la primacía hermenéutica de la "voluntas legislatoris» subyace una «concepción del Derecho según la cual la norma es tal norma, está vigente y posee fuerza vinculante porque así lo ha querido su autor», resultando, a la postre, abiertamente incompatible con un verdadero Estado constitucional, lo que le llevaría a concluir que «en un ordenamiento como el español el argumento histórico, recogido en el artículo 3.1. del Código Civil, sólo puede tener un valor secundario, sin que en ningún caso pueda prevalecer sobre otros cánones hermenéuticos». Cfr., DIEZ-PICAZO, L.M.: «Los preámbulos de las leyes (En torno a la motivación y la causa de las disposiciones normativas)», Anuario de Derecho Civil, Vol. 45, núm. 2, 1992, págs. 520-522.

${ }_{122}$ La citada enmienda del Grupo Socialista decía literalmente así: «1. [E] régimen tributario de las entidades sin fines lucrativos regulado en el Capítulo I del Título II de la Ley 30/1994, de 24 de noviembre], resultará directamente aplicable a las Organizaciones no Gubernamentales de Desarrollo inscritas que cumplan con los requisitos establecidos en el Registro, al que se refiere el artículo 29 [finalmente, art. 32] de la presente Ley». Vid. BOCG, VI Legislatura, serie A, núm. 81-7, de 17 de noviembre de 1997, enmienda núm. 190, pág. 106. La cursiva es mía.

123 Vid., a continuación, el siguiente punto III. 
Pero es que, además, al margen de la siempre complicada apelación a una supuesta voluntas legislatoris, dicha interpretación, como ya tuve ocasión de exponer, encuentra serias objeciones: desde la duplicidad que representa la inscripción en diversos registros a la diferencia en el tratamiento fiscal de ONGDs y ONGs de Acción Social, pasando por la eventual contradicción entre los criterios que pudieran sostener los Protectorados (en el caso de las fundaciones) o los órganos encargados de su declaración de utilidad pública (en el caso de las asociaciones) y los que pudieran mantener el/los encargado/s del Registro/s de ONGDs, si se sostiene, con carácter general, para todas sin excepción, la necesidad de la inscripción en estos últimos como condición indispensable para la aplicación del repetido régimen fiscal, sin olvidar su pérdida para las fundaciones y las asociaciones que, ostentando la declaración de utilidad pública y encontrándose inscritas en el registro correspondiente a su naturaleza, no lo hubieran hecho también en el de la AECID o en los autonómicos de idéntico fin ${ }^{124}$; caso este último que, como vimos, no deja tampoco de suscitar controversia, dada la eventualidad de que los requisitos para el acceso a dichos registros sean diferentes según la Comunidad autónoma en que la ONGD tengan su sede.

III. El tercero y último de los hitos a que me refería es el que representa la aprobación de la Ley 49/2002. Aunque, en mi sentir, todavía van a perdurar algunas dudas, considero que esta Ley permite superar los problemas que había suscitado la Ley 23/1998.

En primer lugar, la Ley 49/2002 habría recuperado el planteamiento de su predecesora, la Ley 30/1994 —si es que la Ley 23/1998 supuso verdaderamente su abandono-, de manera que ya no se trata a las ONGDs cual si constituyeran una categoría independiente e irreducible a la de entidad sin fin de lucro que, no obstante a su singularidad, fuera menester equiparar otorgándoles el mismo tratamiento fiscal, pero bajo las condiciones impuestas no por la Ley tributaria, sino por la norma sectorial — la Ley 23/1998 - que es la que decidiría en última instancia. Si bajo la Ley 30/1994, que, a la postre, mezclaba también en su seno el régimen sustantivo de un concreto tipo de entidades - las fundaciones - y el régimen fiscal de las

124 Téngase en cuenta que el art. 35 de la Ley 23/1998 no establece diferencia alguna por el hecho de estar declaradas de utilidad pública, por lo que cabría argüir que ubi lex non distinguit nec non distinguere debemus. No obstante, un intento de superar estas dificultades sería interpretar correctivamente que la inscripción en el/ los Registro/s de ONGDs como conditio sine qua non para el disfrute del régimen fiscal de las entidades sin fin de lucro sólo rige para las que sean asociaciones no declaradas de utilidad pública. Sobre el tema ya nos hemos referido más atrás. Vid., supra, apdo. IV.A.2. 
entidades sin fines lucrativos, pudiera no ser reprochable que la Ley 23/1998 pretendiera hacer lo propio sustrayendo de aquélla el régimen fiscal de las ONGDs (que es lo que, en suma, cabe entender que pretendió en sus art. 33, 35 y 36), tras la Ley 49/2002 no cabe dicho planteamiento, si es que en algún momento cupo. Ahora nuevamente, sin perjuicio de su «visibilización» en el art. 2.c), se las concibe, a efectos fiscales, como «entidades sin fin de lucro» - no como ONGDs a las que se aplica el régimen fiscal de aquéllas- siempre que cumplan las condiciones y requisitos establecidos en la norma tributaria, lo cual implica, a mi juicio, que la Ley 23/1998 podrá decir qué es o qué no es una ONGD - y ya hemos visto que dicha Ley no condiciona tal consideración a que se encuentren o no inscritas como tales-, pero, en todo caso, las condiciones impuestas por la misma para disfrutar de un determinado tratamiento fiscal, sea el de las entidades sin fin de lucro, sea el de las entidades parcialmente exentas, sólo valen en la medida en que hayan sido expresamente revalidadas por la respectiva norma tributaria.

Recuérdese, como ya expuse al principio de este trabajo, que el régimen de la Ley 49/2002 no es el régimen fiscal de las fundaciones, de las asociaciones de utilidad pública, de las ONGDs... es el régimen fiscal de las «entidades sin fin de lucro». El concepto de «entidad sin fin de lucro» constituye, como la propia Exposición de Motivos de la Ley se encarga de subrayar, uno de los tres pilares básicos en que se apoya dicho régimen especial. Ello implica que sus requisitos y condiciones no pueden interpretarse desde la sola perspectiva del régimen jurídico civil o administrativo que corresponda individualmente a cada una de las figuras inicialmente seleccionadas. Como dije, la consideración de todas ellas como conjunto nos ofrece un patrón de los rasgos y perfiles jurídicos comunes que, juntamente con los requisitos del artículo $3^{\circ}$, constituye una guía interpretativa que nos permite resolver los problemas hermenéuticos que plantean supuestos como el que nos ocupa. En suma, estamos hablando de unas entidades que deben poseer intrínsecamente unas determinadas características en cuyo mérito se las dispensa un tratamiento fiscal beneficioso; a saber, básicamente, la ausencia de fin de lucro, la persecución de fines de interés general y su sometimiento al control y supervisión de la Administración. Y es desde esa perspectiva desde la que ha de resolverse la cuestión de que aquí se trata.

Por otro lado, se debe recordar que la mención del art. 2.c) no se refiere ni se reduce a las ONGDs inscritas en el/los Registros que determina la Ley 23/1998 (indicación ausente en dicho apartado), sino que alude, sin diferenciar, a todas las que sean susceptibles de 
considerarse como tales conforme a la definición contenida en la misma $^{125}$, eso sí, con la importante precisión que añade a renglón seguido: "siempre que tengan alguna de las formas jurídicas a que se refieren los párrafos anteriores»; expresión, sin duda, confusa, como se ha venido repitiendo, pero que cabe interpretar en el sentido de que se las considera entidades sin fines lucrativos siempre que hayan adoptado la forma de fundaciones o de asociaciones que hayan sido declaradas de utilidad pública, en línea con lo que había dispuesto la anterior Ley 30/1994.

$\mathrm{Y}$ a este respecto, no estimo que sea extravagante considerar que el legislador utilizó la expresión como en ocasiones se hace cuando se habla de que una empresa se ha constituido con la forma de sociedad anónima, o de sociedad colectiva, o de cualquier otro tipo de sociedad, para designar una concreta clase. En nuestro caso, no estaría refiriéndose al género -asociación-, sino a una de sus especies o subtipos: las de utilidad pública.

Piénsese que, aunque la expresión no resulte técnicamente muy precisa, las «formas jurídicas» que se les requiere no constituyen un mero ropaje desustantivado: dicha exigencia no es sino un reenvío a las normas que disciplinan dicho tipo de entidades, sin cuyo cumplimiento no podrían adquirir las "formas jurídicas " requeridas. Dicho en otros términos, si se les exige que hayan adoptado determinadas «formas», si se les selecciona como potenciales entidades sin fin de lucro, es porque el régimen que las disciplina anticipa en buena medida los requisitos fiscales que luego se les demandará cumplir. Y una interpretación que diera por suficiente la forma jurídica asociativa prescindiendo de su declaración de utilidad pública, aunque exija su inscripción en el Registro de ONGDs, no resultaría bastante - a pesar del esfuerzo del Reglamento del Registro de la AECID, tensionando la letra de la Ley- para situarlas a la altura del resto de entidades merecedoras de dicho régimen. A la postre, como enseguida veremos, el propio artículo $3^{\circ}$ nos conducirá a rechazar su consideración como entidades sin fin de lucro.

En definitiva, lo que el precepto estaría queriendo decir con dicha controvertida referencia es que ha de tratarse de ONGDs que no sólo carezcan de ánimo de lucro y persigan fines relacionados con la cooperación para el desarrollo - que, en principio, serían requisitos que cumplirían evidentemente todas, conforme a la amplia de-

125 Sin que a ello se oponga el requisito de «estar inscritas en el Registro correspondiente» a que se refiere el art. $3.7^{\circ}$ de la Ley 49/2002, ya que, según se razonó más atrás, éste sería el procedente conforme a su naturaleza. 
finición que de las mismas ofrece el art. 32.1 de la Ley 23/1998-, sino que, además, su actuación ha de encontrarse sujeta al control y supervisión de los órganos competentes de la Administración, no puntualmente, como un elemento accidental derivado de la ejecución de esta o aquella actividad (como de ordinario ocurre en el caso de las subvenciones), sino como un elemento estructural y duradero, ligado a la propia persona jurídica, lo que ya no sería predicable más que de unas muy concretas; a saber, las que sean fundaciones o las que sean asociaciones que hayan sido declaradas de utilidad pública. Recordemos nuevamente que las asociaciones aun cuando sean entidades carentes de ánimo de lucro, ni han de perseguir necesariamente fines de interés general ni quedan sujetas al control de la Administración. Esto último, como se ha dicho, sólo acaece respecto de las declaradas de utilidad pública.

A este respecto, aunque, como ya he señalado, los antecedentes parlamentarios han de contemplarse con mucha cautela, avalaría dicha interpretación la propia tramitación de la Ley 49/2002. Originalmente, en el art. 2.c) del Proyecto de Ley se consideraba como entidades sin fin de lucro a "[l]as organizaciones no gubernamentales de desarrollo a que se refiere la Ley 23/1998, de 7 de julio, de Cooperación internacional para el Desarrollo», sin más añadidos, ni a la forma jurídica, ni a la necesidad de estar inscritas en el Registro de ONGDs, como se precisa respecto de otras entidades, ni a la de haber sido declaradas de utilidad pública en el caso de las asociaciones ${ }^{126}$. La inclusión del inciso que comentamos se introdujo posteriormente: fue debida a la enmienda núm. 141, presentada por el Grupo Parlamentario Popular en el Congreso, que llevaba la siguiente justificación:

«El vigente artículo 35 de la Ley 23/1998, reguladora de las organizaciones a que se refiere esta letra, dispone, en su apartado 1, que únicamente las ONGs de desarrollo que tengan la forma jurídica de fundación o de asociación declarada de utilidad pública, podrán optar por el régimen fiscal especial regulado en el título II de la Ley 30/1994, de 24 de noviembre, de Fundaciones y de Incentivos Fiscales a la Participación Privada en actividades de Interés General. Con la modificación propuesta se pretende recoger este mismo requisito en la letra c) del artículo $2{ }^{127}$

En rigor, como ya hemos visto, el art. 35 de la Ley 23/1998 no decía exactamente que las únicas ONGDs que podían disfrutar del répág. 5

126 Cfr., BOCG, VII Legislatura, Serie A, núm. 106-1, de 20 de agosto de 2002,

127 Cfr., BOCG, VII Legislatura, serie A, núm. 106-9, de 24 de octubre de 2002, pág. 78-79. 
gimen de las entidades sin fin de lucro fuesen las que tuvieran la forma jurídica de fundación o de asociación declarada de utilidad pública, sino que subordinaba la aplicación de dicho régimen fiscal a que revistieran la forma jurídica y cumplieran los requisitos entonces establecidos en el título II de la Ley 30/1994, cuyo art. 41 sí se refería a las fundaciones y a las asociaciones de utilidad pública. Si la exigencia de que "revistieran la forma» alcanzaba a la declaración de utilidad pública era justamente el punctum pruriens, que la enmienda interpreta afirmativamente.

En todo caso, disipando cualquier duda sobre el particular, sucedería que, aprobada la citada enmienda en el Congreso, el Grupo Parlamentario Catalán Convergència i Unió (GPCIU) intentaría en el Senado la vuelta a la redacción inicial del Proyecto de Ley mediante la presentación de la enmienda núm. 86, que no prosperó. El Senador Pardo Gabaldón del Grupo Parlamentario Popular, a la sazón ponente del Proyecto, sería categórico en este punto durante el debate de la Comisión de Hacienda para la aprobación del informe de la Ponencia: "La enmienda número 86 no se aceptaría porque el proyecto de ley exige que todas las ONG sean de utilidad pública»128. Por consiguiente, sobre este particular no cabe duda de cuál fue la intención del Legislativo.

En definitiva, a pesar de que, de esta forma, la mención de las ONGDs en el apdo. c) del artículo $2^{\circ}$ resulta redundante y estéril, pues, en rigor, habrían de entenderse ya incluidas en los párrafos a) y b) de dicho art. $2^{129}$, considero que la exigencia de su último inciso de que tengan "alguna de las formas jurídicas a que se refieren los párrafos anteriores", no puede sino interpretarse en el sentido de que ha de tratarse de fundaciones o asociaciones declaradas de utilidad pública, sin que el requisito de su inscripción en el Registro/s de ONGDs —ausente, como hemos señalado, en dicho art. 2.c) y no requerido tampoco por la Ley 23/1998 como necesaria para «ser» ONGD— altere dicha conclusión, por las razones que se expusieron más atrás.

No hace falta repetir que ello no sólo tiene importancia desde el punto de vista de su régimen tributario. La restricción a las que

128 Vid., BOCG, Senado, VII Legislatura, serie II, núm. 93 (c), de 22 de noviembre de 2002, enmienda núm. 86, págs. 51-52, y Diario de Sesiones del Senado - Comisiones, núm. 385, de 28 de noviembre de 2002, pág. 9.

129 En este sentido, Pedreira Menéndez, J.: El Régimen Fiscal del Sector No Lucrativo y del Mecenazgo. Comentarios a la Ley 49/2002, de 23 de diciembre, de Régimen fiscal de las entidades sin fines lucrativos y de los incentivos fiscales al mecenazgo. Civitas, Madrid 2003, pág. 76, y LóPEz RiBAS, Silvia, «Estatuto fiscal del mecenazgo en la Ley 49/2002», Quincena Fiscal, nº 5/2004 (BIB 2004\213), nota 6.

(c) UNED. Revista de Derecho UNED, núm. 27, 2021 
adopten la forma de fundación o asociación de utilidad pública comporta que las ONGDs que no revistan tales formas no serán susceptibles de ser consideradas «entidades sin fin de lucro» $y$, por consiguiente, tampoco podrán considerarse «entidades beneficiarias del mecenazgo", lo que significa que las donaciones, aportaciones y donativos que pudieran realizarse a favor de las mismas no podrán disfrutar de los incentivos previstos en el título III de la Ley 49/2002.

Señala críticamente sobre este particular PEDREIRA MENÉNDEZ ${ }^{130}$, que la redacción definitiva de este art. 2.c) supone «un serio desincentivo a la colaboración privada en actividades al desarrollo, todo lo contrario de lo que pretendía la Ley 23/1998». Sin embargo, fuere cual fuere el propósito que quepa atribuir a dicha Ley, es lo cierto que, de no haberse hecho esa salvedad, se llegaría a una situación que quizá para muchos tampoco pudiera considerarse congruente, puesto que daría lugar a que unas asociaciones no declaradas de utilidad pública pudieran beneficiarse del régimen fiscal de la Ley 49/2002 - las que tuvieran como fin u objeto expreso la cooperación al desarrollo- y, en cambio, otras asociaciones, igualmente no declaradas de utilidad pública y dedicadas asimismo a fines de interés general, no pudieran acogerse a dicho régimen (así, las ONG de Acción Social). Es probable que los acuciantes problemas del tercer mundo y de los países en vías de desarrollo reclame una mayor solidaridad y sensibilidad de las sociedades más prósperas, no seré yo quien lo cuestione, pero no estoy seguro de que todas las organizaciones que cabría incluir bajo la rúbrica de la cooperación al desarrollo, deban disfrutar de mayores ventajas - rectius: deban someterse a menores exigencias- que otras asociaciones que prestan servicios en ámbitos como la drogadicción, el alcoholismo, la marginación, etc., por el hecho de que, en vez de dirigir su atención a otros países más pobres, lo hagan a los sectores sociales más desfavorecidos dentro del propio país. Éste es, en todo caso, un juicio político, que no sólo es perfectamente lícito, sino incluso necesario en una sociedad democrática, pero consideramos que esa diferenciación, si se admite, debiera llegar no por la vía de la exclusión de requisitos. En otras palabras, si la adopción de una forma jurídica determinada constituye un serio desincentivo, deberíamos entonces cuestionarnos por qué mantener esa exigencia, pero no sólo respecto de las ONGDs. Otra cuestión distinta ${ }^{131}$ es la confusión a que puede inducir el que entidades que aparecen bajo la misma denominación

130 Pedreira Menéndez, El Régimen Fiscal del Sector No Lucrativo..., op. cit., pág. 77 , nota 113 ).

131 Vid, también, PedreIRA, Ibídem, pág. 77 
de ONGDs, inscritas en los mismos registros y con los mismos fines, en unos casos puedan dar lugar a la deducción de las donaciones o aportaciones efectuadas a las mismas, por tener la forma de fundación o asociación de utilidad pública, y en otros no, por carecer de dichas formas, lo que puede resultar difícil de discernir al eventual mecenas. En este sentido, que es bajo el que se efectúa la crítica del autor citado, convenimos en que la inclusión de este precepto en la Ley 49/2002 puede resultar no sólo superflua, sino incluso perturbadora; pero la inseguridad a que alude el reiterado autor podría plantearse también respecto de otras entidades: piénsese en dos fundaciones, una acogida al régimen especial de la Ley 49/2002 y otra no. Por consiguiente, el problema a que apunta es un problema de carácter general, y no específico de las ONGDs, que se refiere a la publicidad del disfrute de este régimen fiscal -o más exactamente, de su condición de entidades beneficiarias del mecenazgo- como presupuesto de la certidumbre jurídica de los terceros interesados.

En todo caso, debe señalarse que no ha sido éste, sin embargo, el criterio expresado por la Dirección General de Tributos en la contestación a diversas consultas, en las que sostendrá — sin argumento alguno- que no es preciso que las ONGDs que tengan la forma de asociación estén declaradas de utilidad pública para disfrutar del régimen de la Ley 49/2002, siendo suficiente con que se encuentren inscritas en el Registro de la AECID. Así, en las de 18 de enero de 2006 (V0098-06); 14 de enero de 2008 (V0071-08); 22 de enero de 2009 (V0126-09); de 30 de mayo de 2012 (V1175-12) y 28 de febrero de 2013 (V0614-13) $)^{132}$.

132 Debo aclarar que la contestación a la consulta 0529-00, de 10 de marzo de 2000, apuntada por Vidal Wagner, De URrutia Coduras y Esouerra Miramunt (cit.) como exponente del criterio inicial de la DGT en el sentido de que «solamente resultaba aplicable dicho incentivo fiscal [se refieren los autores al art. 68 de la Ley 30/1994] en la medida en que las ONGD a las que se refería el escrito de consulta fuesen, principalmente, fundaciones o tuviesen la consideración de asociaciones declaradas de utilidad pública» (Ibidem, pág. 32, nota 6), no resulta, a mi juicio, en modo alguno concluyente (es más, me inclino a considerar que no se refería particularmente a las ONGDs) y, antes al contrario, incluso serviría para justificar el criterio opuesto.

Se ha de advertir que lo que la contestación a dicha consulta decía literalmente es que "si las organizaciones no gubernamentales a las que se refiere el escrito de consulta son fundaciones, asociaciones declaradas de utilidad pública $u$ otras entidades a las que resulte aplicable la ley citada, podría ser aplicable el incentivo fiscal previsto en el artículo 68 de la citada Ley relativo a los convenios de colaboración en actividades de interés general». Nótese: «...asociaciones declaradas de utilidad pública u otras entidades a las que resulte aplicable la ley citada». Pues bien, cabe considerar que entre esas "otras entidades» se encontraban las ONGDs. Convendrá recordar a ese respecto, por un lado, que la consulta se formulaba en relación al patrocinio de "organizaciones no gubernamentales», 


\section{No podemos compartir dicha postura, que, en mi sentir, no solo}

mencionadas genéricamente, sin precisar su objeto. Así, en la descripción de los hechos menciona el patrocinio de «obras sociales» y alude luego a «la realización de su actividad deportiva, benéfica, cultural, científica o de otra índole»; ergo, en el mejor de los casos, podía tratarse tanto de ONGs de desarrollo como ONGs de acción social. Y por otro, convendrá recordar también que el art. 35.4 de la Ley 23/1998, significativamente omitido en la contestación, disponía específicamente sobre el particular que "Las aportaciones efectuadas por personas físicas y jurídicas a organizaciones no gubernamentales de desarrollo incluidas en el ámbito de la aplicación de la Ley 30/1994, de 24 de noviembre, darán derecho al disfrute de los incentivos contemplados en el capítulo II del Título II de dicha Ley», donde justamente se ubicaba el aludido art. 68. En este sentido, no deja de sorprender la omisión de la cita de dicho art. 35.4 si la consulta se hubiera evacuado en relación a las ONGDs. En todo caso, si, como afirman los referidos autores, la DGT interpretaba que el citado art. 68 solamente era aplicable a las ONGDs que fueran fundaciones o asociaciones que estuvieran declaradas de utilidad pública, la expresa referencia a "otras entidades» holgaba por entero. En mi opinión, por un lado, la alusión a las fundaciones y asociaciones de utilidad pública encajaba perfectamente en el art. 41 de la Ley 30/1994, siendo válida en relación a las entidades sin fin de lucro, en general, y, por otro, en la alusión a «otras entidades $a$ las que resulte aplicable la ley citada» cabía entender comprendidas tanto las ONGDs (sobre las que, en todo caso, la contestación de la DGT no se detiene a dilucidar si han de estar o no declaradas de utilidad pública) como otras entidades que por su forma y condiciones no son reconducibles a la de fundaciones o asociaciones de utilidad pública, pero a las que resultaba igualmente aplicable la Ley 30/1994, como sería el caso de las distintas entidades de que se ocupaban las disposiciones adicionales de dicha Ley. En definitiva, a mi juicio, la contestación a la consulta 0529-00 no sirve para ilustrar sobre el criterio que en ese momento mantenía la Administración Tributaria.

En cuanto a la contestación a la consulta vinculante V2469-05, de 7 de diciembre, citada igualmente por los referidos autores (cfr. Vidal WaGner, De Urrutia Coduras y Esquerra Miramunt, cit., pág. 35), tampoco me resulta concluyente, aunque su (confusa) literalidad sí parece dar a entender —al menos en una de sus lecturas- que en aquel caso, a diferencia de las que se han citado en el texto, la DGT acogió el criterio favorable a considerar exigible la declaración de utilidad pública en el caso de las ONGDs constituidas como asociaciones. Se ha de señalar que esta consulta, dictada ya en relación a la Ley 49/2002, se refiere a una "asociación benéfico y cultural sin ánimo de lucro» (sic), entre cuyos fines menciona «la creación y desarrollo de iniciativas a favor de los sectores marginales de nuestra sociedad y especialmente la atención y ayuda a la infancia en el tercer mundo». Por consiguiente, según esa descripción, se movería, en principio, tanto en el ámbito de las ONGs de acción social como en el de las de cooperación al desarrollo. En la contestación, luego de recordar que el artículo 2 de la Ley 49/2002 considera entidades sin fines lucrativos tanto a las asociaciones declaradas de utilidad pública como a las organizaciones no gubernamentales de desarrollo a que se refiere la Ley 23/1998, siempre que cumplan los requisitos establecidos en su artículo 3, concluirá, tras la reproducción de dicho precepto, que si la asociación consultante cumple dichos requisitos y se acoge al régimen fiscal de la Ley 49/2002, podrá tener la consideración de entidad beneficiaria del mecenazgo. "Por el contrario continuaría-, caso de que la entidad consultante no cumpla las condiciones para ser considerada como entidad sin fines lucrativos a que se refiere la Ley 49/2002, ni tenga la consideración de asociación de utilidad pública, los donativos percibidos no generan deducción a deducción en la cuota del IRPF de los donantes». Pues 
supone desconocer la filosofía que inspira la Ley en orden a la selección de entidades y los requisitos que éstas deben reunir para hacerse merecedoras de la consideración de ESFL, sino que introduce, además, como ya he señalado, una clara discriminación, tanto respecto de los demás sujetos susceptibles de recibir dicha consideración, como respecto de los que no pueden hacerse acreedores de dicho tratamiento por incumplir un requisito del que injustificadamente se dispensa a estas organizaciones. Acaso pudiera resultar comprensible una solución de este tipo, si la DGT hubiera intentado la equiparación - la extensión del régimen fiscal especial- sólo respecto a determinadas ONGDs que, aun no siendo fundaciones ni habiendo obtenido la mencionada declaración de utilidad pública, se encuentran sometidas a un procedimiento y control equiparables, como es el caso de las "ONGDs calificadas»" ${ }^{133}$, cuyo régimen goza de cierta estabilidad (así, no se encuentra vinculada a la resolución

bien, aunque no se desprende con certeza si se refiere a los requisitos del art. 3 o a la tipología jurídica que se exige en el art. 2 para tener la consideración de entidad sin fin de lucro —nótese que aquí habla de «condiciones»-, lo cierto es que, caso de que se refiriese a los requisitos del art. 3, la expresión que sigue - «ni tenga» la consideración de asociación de utilidad pública- resulta, desde luego, muy poco afortunada. Adviértase que, en tal caso, lo correcto habría sido decir "o' no tenga», porque es suficiente con no cumplir los requisitos $o$ con no tener la consideración de asociación de utilidad pública. No serían precisas ambas cosas —que es lo que literalmente afirma - para no resulte aplicable el beneficio. A no ser - y por eso decía anteriormente que la contestación no me resulta concluyente- que estuviese refiriéndose a que la entidad consultante no cumpla las condiciones para ser una ONGD y poder ser considerada por esta vía entidad sin fin de lucro (recordemos que los fines de la asociación se movían entre la cooperación al desarrollo y la acción social); supuesto en el que la expresión «ni tengan» sí sería adecuada, pues, en tal caso, para que no resultase aplicable el beneficio sería menester que careciera también de la consideración de asociación de utilidad pública.

Finalmente, hemos de anotar la contestación a la consulta vinculante V216814, de 6 de agosto de 2014, que parece acoger un criterio distinto al de las consultas citadas en el texto, en la medida en que supedita la aplicación del régimen especial de la Ley 49/2002 a que la ONGD «revista la forma jurídica de fundación o de asociación declarada de utilidad pública». Como señalan, asimismo, los autores antes citados, de la literalidad de la contestación a dicha consulta «parece razonable entender que la DGT considera necesaria 'ahora' la declaración de utilidad pública en el caso de una ONGD constituida con forma jurídica de asociación» (cfr. VIDAL Wagner, De Urrutia Coduras y Esquerra Miramunt, cit., pág. 35). Aunque, en mi sentir, lamentablemente, aún nos deja en la duda de si se trata verdaderamente de un cambio de doctrina, pues no afirma, ni justifica el cambio de parecer.

133 Convienen en que lo procedente hubiera sido limitar el acceso al régimen de la Ley 49/2002 a las "ONGDs calificadas», Blázouez Lidoy, A. y MARTín DÉGANO, en Manual tributario de entidades no lucrativas (asociaciones y fundaciones). Centro de Estudios Financieros, Madrid, 2012, p. 31. 
de la convocatoria de una concreta subvención), aunque tal consideración se produzca desde la vertiente del gasto público ${ }^{134}$.

En efecto, la Orden AEC/1303/2005, de 27 de abril, por la que se regulaban las bases para la concesión de subvenciones a ONGDs para la realización de intervenciones en materia de cooperación internacional para el desarrollo ${ }^{135}$, vendría a instaurar los principios generales del denominado "procedimiento de calificación», que se establecería con la finalidad de acreditar a aquellas ONGDs que, de acuerdo a su estructura y capacidad — probada mediante una valoración objetiva y minuciosa-, reúnen las aptitudes oportunas para actuar en la consecución compartida de objetivos de desarrollo generales con la AECID ${ }^{136}$.

134 A este respecto, puede ser oportuno reseñar un dato: según el Portal Web de la AECID, «de entre el total de las ONGD españolas — hay más de 2000 inscritas en el Registro de ONGDs dependiente de la misma, según se hace constar en el mismo sitio- la Agencia española concentra la financiación en 42 de ellas, las llamadas "ONGD calificadas", que han pasado un proceso de acreditación que certifica su experiencia y capacidad». Cfr.: http://www.aecid.es/ES/la-aecid/nuestros-socios/ ongd, fecha último acceso 28/09/2018.

135 BOE núm. 113, de 12 de mayo.

136 Vid., la Base Sexta, apdo. 1, de la citada Orden AEC/1303/2005. Debe apostillarse que dicha Orden venía a desarrollar el Real Decreto 794/2010, de 16 de junio, por el que se regulan las subvenciones y ayudas en el ámbito de la cooperación internacional (BOE núm.154, de 25 de junio), al amparo de lo dispuesto en su disposición final primera y que, junto a la Orden AEC/442/2007, de 23 de enero, que establecía las bases reguladoras de la concesión de subvenciones de la convocatoria abierta y permanente para actividades de cooperación y ayuda al desarrollo, sería modificada en aspectos puntuales de tipo organizativo por la Orden AEC/460/2008, de 11 de febrero (BOE núm. 49, de 26 de febrero de 2008). Posteriormente, ambas serían derogadas por la Orden AEC/2909/2011, de 21 de octubre (BOE núm. 261, de 29 de octubre), por la que se establecen las bases para la concesión de subvenciones de cooperación internacional para el desarrollo, pero con la excepción, en el caso de la Orden AEC/1303/2005, de su Base Sexta —vid. el apartado a) de la Disposición derogatoria única-que es donde se regula el procedimiento de acreditación como «ONGD calificada» a que nos estamos refiriendo en el texto.

Es pertinente consignar asimismo, como complemento de lo expuesto, que la referida Base Sexta no solo regula el procedimiento, sino que establece igualmente la posibilidad de que la AECID revise o incluso revoque la acreditación concedida cuando aparezcan indicios que cuestionen la permanencia de las circunstancias en cuyo mérito obtuvieron la condición de ONGD calificada, o cuando se hubiera producido un cambio sustancial en aquéllas. La referida Orden, en fin, ha sido desarrollada por diversas resoluciones, siendo la última aprobada la Resolución de 17 de septiembre de 2013, de la Presidencia de la AECID, por la que se establece el procedimiento para la obtención, revisión y revocación de la calificación por las organizaciones no gubernamentales de desarrollo (BOE núm. 250, de 18 de octubre), modificada, a su vez, por Resolución de la Presidencia de dicho Organismos de 26 de julio de 2017 (BOE núm. 180, de 29 de julio). 
En este sentido, aunque desde un punto de vista riguroso y formal, dicha solución hubiera resultado jurídicamente difícil de sostener - a mi juicio, sería necesaria no una resolución interpretativa, sino una norma jurídica que estableciera la equiparación entre las «ONGDs calificadas» y las asociaciones de utilidad pública ${ }^{137}$-, al menos, desde el punto de vista material, la solución no resultaría tan reprochable. Porque lo que carece de justificación y pugna con los más elementales principios de justicia es que cualquier ONGDs, por mucho que sea un persona jurídico-privada sin ánimo de lucro y persiga finalidades orientadas a la cooperación al desarrollo, pueda disfrutar del régimen fiscal especial, sin control, ni rendición de cuentas de su actuación, a diferencia de todos los demás sujetos del mismo régimen. Ello no sólo contrasta con el tratamiento que reciben las fundaciones y demás asociaciones de utilidad pública, sino que resulta incoherente con la concesión de subvenciones a las propias ONGDs, respecto de las que no es suficiente que se hayan inscrito en el Registro de la AECID para que puedan disfrutar de la posibilidad de celebrar convenios con dicha Agencia y beneficiarse de las ayudas que éstos llevan anudados, debiendo obtener la referida calificación y, por tanto, habiendo de cumplir unos requisitos que, como se ha explicado, no distan de los que se exige para la declaración de utilidad y aun en ciertos extremos resultan más rigurosos. No hay, en suma, una explicación objetiva y razonable que permita justificar el privilegio que se sigue de la interpretación que venía dándose por la Administración tributaria.

Es más, aunque no se requiriera la declaración de utilidad pública para el caso de las ONGDs que sean asociaciones y, por consiguiente, éstas no viniesen obligadas a rendir cuentas de su actuación desde el punto de vista del régimen jurídico que las disciplina, no por ello se encontrarían dispensadas de cumplir todos los demás requisitos que el art. 3 de la Ley 49/2002 establece, como se cuida de señalar en las contestaciones a que nos hemos referido. En este sentido, cabría argumentar que dicha Ley parte de la premisa de que to-

137 En esa línea, tal vez, hubiera bastado adicionar, bien al Real Decreto 1740/2003, de 19 de diciembre, por el que se regulan los procedimientos relativos a asociaciones de utilidad pública, bien al Reglamento por el que se regula el Registro de ONGDs, una disposición en la que se reconociera el proceso de obtención de la acreditación como "ONGD calificada» como un procedimiento especial de declaración de utilidad específico para las ONGDs. O, más simplemente, que declarara su equivalencia a efectos del disfrute de las subvenciones e incentivos fiscales que se reconocen a las declaradas de utilidad pública. Adviértase que ello, además de simplificar, alinearía las dos vertientes financieras, la del ingreso y la del gasto, y ambas, a su vez, con los objetivos extrafiscales a cuya consecución se enderezan subvenciones y beneficios fiscales. 
das las entidades susceptibles de ser consideradas como entidades sin fin de lucro han de rendir cuentas, sin excepción. A ese respecto se ha de recordar que el referido art. 3 les exige en su apartado $9^{\circ}$ : "que cumplan las obligaciones de rendición de cuentas que establezca su legislación específica», señalando seguidamente que "en ausencia de previsión legal específica, deberán rendir cuentas antes de transcurridos seis meses desde el cierre de su ejercicio ante el organismo público encargado del registro correspondiente» ${ }^{138}$.

Pues bien, ni en la Ley 23/1998, ni en el antiguo, ni en el actual Reglamento que regula el Registro de ONGDs se previene el depósito de las cuentas, ni se establece un procedimiento para que las ONGDs que se inscriban en el mismo puedan rendirlas ante el Ministerio de Asuntos Exteriores y Cooperación o ante la AECID, en cuanto encargada de aquél. Recordemos a este respecto, que si bien el art. 14 de la LODA establece el deber de que las asociaciones lleven «una contabilidad que permita obtener la imagen fiel del patrimonio, del resultado y de la situación financiera de la entidad», así como un inventario de sus bienes y una memoria de las actividades realizadas, lo cierto es que asociaciones no declaradas de utilidad pública no tienen el deber de rendir cuentas de su actuación más que ante sus asociados, a diferencia de las fundaciones de competencia estatal y de las asociaciones declaradas de utilidad pública, que han de hacerlo, respectivamente, ante el Protectorado (art. 25

138 El precepto plantea, no obstante, importantes dudas interpretativas. Así, desde una lectura literal, cabría considerar que el apartado en cuestión se limita a «reforzar» la exigencia que, en su caso, ya viniere impuesta por la normativa sustantiva por la que se rijan, pero no a imponer ex novo un requisito a que no estuvieran ya sometidas. Desde esa perspectiva, «la ausencia de previsión legal específica» se referiría solamente al supuesto de que dicha normativa no contuviera una mención al "plazo», no a la inexistencia de tal obligación. Otra interpretación, bien diferente, sería considerar que cuando se refiere a que cumplan las obligaciones de rendición de cuentas "que establezca su legislación específica», no está contemplando la posibilidad de que la normativa por la que se rijan pueda no exigirles tal obligación (de manera que en ese supuesto hubiera de entenderse que quedan también dispensadas del cumplimiento de dicho requisito en el ámbito de este régimen fiscal), sino que, distintamente, partiendo siempre de que la rendición de cuentas es un requisito inexcusable para que puedan ser consideradas ESFL, lo que viene a decir dicho inciso es que no las impone una forma determinada a que haya de ajustarse dicha rendición, remitiendo en ese aspecto a lo que disponga el régimen sustantivo de cada una de ellas y supliendo seguidamente lo menester, en caso de ausencia de una específica previsión legal; interpretación esta última, que se robustece si se tiene en cuenta que todas las entidades que se mencionan en su artículo 2, desde las fundaciones a las federaciones deportivas, son entidades sujetas al control y supervisión de la Administración, aunque pueda haber diferencias en la forma de manifestarse esa tutela y en la manera de producirse dicha rendición. 
Ley 50/2002) y ante el órgano encargado de verificar su constitución y de efectuar su inscripción en el Registro correspondiente (art. 34.1 LODA y art. 5 del RD 1740/2003).

La consecuencia sería, pues, que, aun admitiendo cumplido el requisito del art. 2 en punto a la forma, no se verificaría el establecido en el art. 3.9 y, por tanto, no podrían disfrutar del régimen fiscal especial de la Ley 49/2002.

En efecto, como se indicaba al inicio de este trabajo y hemos recordado anteriormente, el régimen fiscal de la Ley 49/2002 no es el régimen fiscal de las fundaciones y las asociaciones de utilidad pública, sino el régimen fiscal de las «ESFL». Del análisis del art. 2 en su conjunto y de los requisitos establecidos en el artículo 3 se desprende que éstas son entidades que necesariamente han de rendir cuentas de su actuación ante la Administración Pública. La circunstancia de que el régimen jurídico sustantivo por el que se regulen no imponga tal exigencia a alguna de ellas (como en otro supuesto sucede, por ejemplo, en el caso de las fundaciones en relación al destino de sus bienes en caso de disolución ${ }^{139}$ ) no significa que, a efectos de su consideración como ESFL, pueda prescindirse del cumplimiento del mismo en base a no estar previsto en su régimen sustantivo. En definitiva, a través de esta otra vía (en la que el acento se marcaría en que no están sujetas a un régimen de control y supervisión) llegaríamos también a la misma solución: no es posible que disfruten del régimen de la Ley 49/2002, porque ni son entidades sin fin de lucro, en el sentido de dicha Ley, ni se las equipara a las mismas.

\section{CONCLUSIONES}

El tratamiento fiscal de las ONGDs a partir de la Ley 23/1998, de Cooperación Internacional para el Desarrollo, ha tenido una letra lo suficientemente ambigua como para determinar que la interpretación dada desde la propia Administración tributaria haya sido más que vacilante. Si en un inicio, bajo la sola vigencia de la Ley 30/1994, las ONGDs no aparecían especialmente subrayadas en su texto, aun-

139 Como es sabido, ciertas normativas autonómicas permiten que los bienes y derechos resultantes de la liquidación de una Fundación extinguida puedan tener el destino previsto por el fundador, siendo que el apartado $6^{\circ}$ del art. 3 de la Ley 49/2002 impone, por el contrario, que su patrimonio se destine en su totalidad a alguna de las entidades consideradas como entidades beneficiarias del mecenazgo y que esa circunstancia esté expresamente contemplada en el negocio fundacional o en los estatutos de la entidad disuelta. Vid., art. 3.6 Ley 49/2002, art. 27 de la Ley de Fundaciones de la CAM y STC 341/2005, de 21 diciembre. 
que, desde luego, sus fines estaban expresamente contemplados en dicha Ley y, por consiguiente, podían gozar del régimen tributario especial que la misma entronizaba siempre que cumplieran los requisitos formales y materiales que establecía (entre los que se encontraba la declaración de utilidad pública en el caso de las asociaciones), en igualdad con otras entidades sin fin de lucro dedicadas a fines de interés general, es lo cierto que el afán omnicomprensivo que presidiría el dictado de la posterior Ley 23/1998 llevaría a dicha Ley sectorial a la incorporación a su texto de los aspectos fiscales y otras medidas de fomento a la cooperación no gubernamental, otorgándose, en ese sentido, una especial atención a las ONGDs. Lo desafortunado es que para dar notoriedad a dicho tipo de fines y organizaciones se pusiera en riesgo no sólo la seguridad jurídica en punto al alcance del régimen fiscal de la Ley 30/1994, que se quiso que mantuvieran, sino la propia igualdad de trato entre entidades sin fin de lucro, cuyos fines de interés general (a diferencia de épocas pasadas, en los que se distinguía entre benéficos, culturales, científicos, docentes...) recibían en la misma un tratamiento fiscal uniforme, sin perjuicio de la posibilidad general de priorizar ciertas actividades, pero en el ámbito de los incentivos al mecenazgo, no en el de su propio régimen tributario.

No obstante, a pesar de la literalidad de ciertos preceptos de la Ley 23/1998 (señaladamente, de sus artículos 33.2, último inciso, y 35), que, conforme a algunas de las hipótesis que hemos examinado, de estimarse vigentes, requerirían cierta interpretación correctiva, estimo que, a la postre, no hay méritos suficientes para entender que esta última Ley quisiera suprimir esa igualdad, modificando la Ley 30/1994 en relación a las ONGDs, sino que más bien, con independencia del juego parlamentario y las declaraciones políticas que impregnaron su tramitación, su pretensión fue fundamentalmente «pedagógica», en el sentido de que, más que innovar, quiso reproducir lo que ya resultaba de la aplicación de las normas fiscales en aquel momento vigentes. Aunque, ciertamente, como hemos visto, se ha de reconocer que no faltaban argumentos para sostener su intención de erigir a las ONGDs como una «nueva categoría» de entidades sin fin de lucro, cuya definición desbordaría el concepto adoptado por la Ley 30/1994 - ceñido a las fundaciones y a las asociaciones declaradas de utilidad-, pero a las que, no obstante, respetando la "forma», se les habría atribuido el mismo régimen fiscal que a éstas, lo que - según una línea interpretativa que no comparto-, equivalía a que aquellas ONGDs constituidas como "asociación» pudieran disfrutar del régimen tributario especial establecido por dicha Ley, estuvieran o no declaradas de utilidad pública, con tal de que estuvie- 
ran inscritas en el/los Registros de ONGDs (en principio, tanto en el de la AECID como en los autonómicos de idéntica naturaleza), a diferencia de lo que sucedía con el resto de asociaciones que pudieran perseguir igualmente fines de interés general.

En todo caso, aunque la posterior Ley 49/2002 no constituye precisamente un dechado de perfección técnica y en cierta medida parece reproducir los defectos y ambigüedades de la Ley 23/1998 - lo que, de nuevo, trae como consecuencia que se puedan seguir sosteniendo interpretaciones disímiles-, me inclino a considerar, entre las distintas lecturas que se han examinado, que la Ley 49/2002 se encuentra no sólo más próxima al tratamiento homogéneo que inició su predecesora, la Ley 30/1994, sino que decididamente abunda en esa misma línea, desentendiéndose de una singularización de las ONGDs que las convirtiera en entidades privilegiadas - privilegio que, en rigor, solo alcanzaría a las que fueran asociaciones- respecto de otras entidades sin fin de lucro también con forma de asociación que, en defecto, de su declaración de utilidad pública, se ven abocadas a aplicar el régimen fiscal de las entidades parcialmente exentas y no el de las entidades sin fin de lucro, con la importante consecuencia de que tampoco podrían ser consideradas entidades beneficiarias del mecenazgo, perdiendo atractivo para la financiación privada. Se debe tener presente que el régimen de la Ley 49/2002 no es el régimen fiscal de las fundaciones, de las asociaciones de utilidad pública, de las ONGDs... es el régimen fiscal de las «entidades sin fin de lucro». El concepto de «entidad sin fin de lucro» constituye, como la propia Exposición de Motivos de la Ley se encarga de subrayar, uno de los tres pilares básicos en que se apoya dicho régimen especial. Ello implica que sus requisitos y condiciones no pueden interpretarse desde la sola perspectiva del régimen jurídico civil o administrativo que corresponda individualmente a cada una de las figuras inicialmente seleccionadas, de manera que, en mi sentir, más allá del brindis a la visibilidad de dichas entidades que supone su expresa mención en la letra c) de su artículo 2, hay que considerar superados — suprimidos- los particularismos que, eventualmente, cupiera entender que dispuso la Ley 23/1998, considerando por tales la dispensa de la declaración de utilidad pública en el caso de las asociaciones y la obligatoriedad, con carácter general para todas las ONGDs, de su inscripción en el Registro de la AECID (o en los autonómicos, en su caso) como requisito sine qua non para el disfrute del régimen fiscal de las entidades sin fin de lucro; obligatoriedad de registro cuya duplicidad $-\mathrm{o}$ triplicidadcon su inscripción en otros, tanto en razón de su naturaleza como de su ámbito territorial, y con la propia evaluación que ya se realiza por los Protectorados (en el caso de las fundaciones) o los órganos encar- 
gados de su declaración de utilidad pública (en el caso de las asociaciones), no se compadece, a mi modo de ver, con las exigencias constitucionales del derecho de asociación y, más ampliamente, con la participación de todos los ciudadanos, y de los grupos en que se integran, en la vida política, económica, cultural y social (art. 9.2 CE).

La letra del propio art. 2.c) de la Ley 49/2002, en la que no en vano se omite toda referencia a que su consideración como ESFL y la aplicación del régimen fiscal solo procedería respecto de las ONGDs «inscritas», resulta bien elocuente y expresiva, tanto si se compara con la letra del art. 35.1 de la Ley 23/1998, en la que se hace expresa (y redundante) mención a dicha exigencia, como con la referencia a otras entidades contenida en el mismo art. 2 de la Ley 49/2002, como es el caso de las delegaciones de fundaciones extranjeras, respecto de las que, a diferencia de las ONGDs, se subraya que han de estar «inscritas» en el Registro (en ese caso, de Fundaciones), habiendo de entenderse, en esa línea, que el "registro correspondiente» a que, con carácter general, se refiere luego el art. 3.7 de la Ley 49/2002 es aquel que permita verificar o constituya un paso previo de la constatación de que se trata de entidades que carecen de fin de lucro y persiguen fines de interés general, facilitando el control y vigilancia de la Administración - lo que no sucede de igual manera con la inscripción en el Registro de la AECID, pese al intento reglamentario- por lo que, en principio, el registro a que alude dicho art. 3.7 no podría ser otro que el correspondiente a su naturaleza jurídica.

En suma, tras la Ley 49/2002, la obligatoriedad de su inscripción en el registro de ONGDs (en el de la AECID o en los autonómicos) sólo procede como condición para que puedan ser beneficiarias de subvenciones y ayudas computables como AOD, sin que tal inscripción las libere de estar declaradas de utilidad pública para poder acogerse al régimen fiscal establecido por esta Ley.

A este respecto, el examen del actual Reglamento del Registro estatal de ONGDs conduce a considerar que se excedió en su papel. Impregnado de cierto aroma recentralizador y particularista, fruto de la respuesta condicionada tanto por la percepción de la creciente - y en ocasiones desconcertante- actividad internacional de las CCAA, como por el imparable protagonismo de las ONGDs, que de su práctica irrelevancia han pasado a gestionar un cuantioso volumen de recursos con destino a la cooperación internacional, lo que le ha conducido a promover, por encima de su finalidad fundamental -la publicidad- a un tipo de entidades con capacidad de gestión, el Reglamento del Registro de la AECID abordaría su propósito 
asido de la tributación como vía justificadora, a semejanza de la declaración de utilidad pública, pero situando el centro de gravedad en dicha Agencia estatal, tanto frente a los registros correspondientes a su naturaleza jurídica y a los órganos encargados de su declaración de utilidad pública como en relación a los registros autonómicos de idéntico fin, respecto de los que deja en duda la suficiencia de la inscripción en los mismos para disfrutar del régimen fiscal especial de las ESFL o la posible diferencia en los requisitos para el acceso a dichos registros y, por ende, al disfrute del repetido régimen fiscal, según el lugar en que se hayan inscrito. Todo lo cual, con independencia de que pueda o no compartirse el designio perseguido, hubiera requerido, a mi juicio, algo más que una mera norma reglamentaria, especialmente en lo que se refiere a los condicionamientos al régimen fiscal especial de la Ley 49/2002. 
